\title{
A novel fuzzy-logic control strategy minimizing N2O emissions
}

\author{
Boiocchi, Riccardo; Gernaey, Krist; Sin, Gürkan
}

Published in:

Water Research

Link to article, DOI:

10.1016/j.watres.2017.06.074

Publication date:

2017

Document Version

Peer reviewed version

Link back to DTU Orbit

Citation (APA):

Boiocchi, R., Gernaey, K., \& Sin, G. (2017). A novel fuzzy-logic control strategy minimizing N2O emissions. Water Research, 123, 479-494. https://doi.org/10.1016/j.watres.2017.06.074

\section{General rights}

Copyright and moral rights for the publications made accessible in the public portal are retained by the authors and/or other copyright owners and it is a condition of accessing publications that users recognise and abide by the legal requirements associated with these rights.

- Users may download and print one copy of any publication from the public portal for the purpose of private study or research.

- You may not further distribute the material or use it for any profit-making activity or commercial gain

- You may freely distribute the URL identifying the publication in the public portal

If you believe that this document breaches copyright please contact us providing details, and we will remove access to the work immediately and investigate your claim 


\section{Accepted Manuscript}

A novel fuzzy-logic control strategy minimizing $\mathrm{N}_{2} \mathrm{O}$ emissions

Riccardo Boiocchi, Krist V. Gernaey, Gürkan Sin

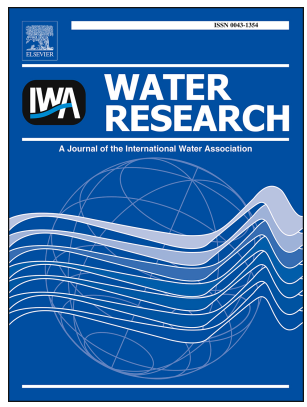

PII: $\quad$ S0043-1354(17)30550-X

DOI: $\quad$ 10.1016/j.watres.2017.06.074

Reference: WR 13029

To appear in: Water Research

Received Date: 23 December 2016

Revised Date: 30 May 2017

Accepted Date: 26 June 2017

Please cite this article as: Boiocchi, R., Gernaey, K.V., Sin, Gü., A novel fuzzy-logic control strategy minimizing $\mathrm{N}_{2} \mathrm{O}$ emissions, Water Research (2017), doi: 10.1016/j.watres.2017.06.074.

This is a PDF file of an unedited manuscript that has been accepted for publication. As a service to our customers we are providing this early version of the manuscript. The manuscript will undergo copyediting, typesetting, and review of the resulting proof before it is published in its final form. Please note that during the production process errors may be discovered which could affect the content, and all legal disclaimers that apply to the journal pertain. 


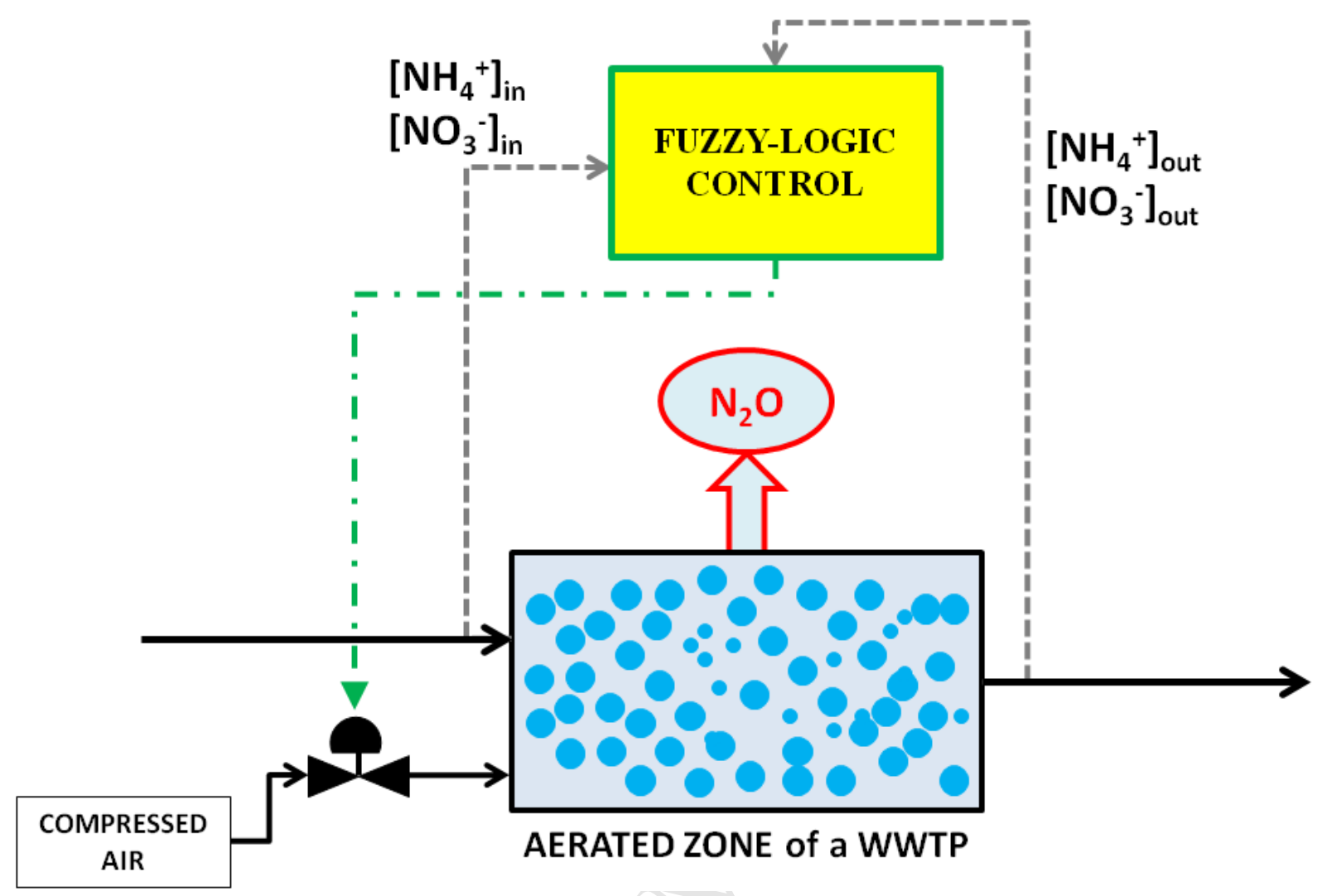




\title{
A novel fuzzy-logic control strategy
}

\section{minimizing $\mathrm{N}_{2} \mathrm{O}$ emissions}

\author{
Riccardo Boiocchi*, Krist V. Gernaey* and Gürkan Sin*(a)
}

*Process and Systems Engineering Center (PROSYS), Department of Chemical and Biochemical Engineering, Technical University of Denmark, Building 229, 2800 Kgs. Lyngby, Denmark

(a) Corresponding author

- A fuzzy-logic control strategy for low $\mathrm{N}_{2} \mathrm{O}$ emissions is systematically developed,

- The control strategy is simulated for different $\mathrm{N}_{2} \mathrm{O}$ formation mechanisms,

- Effluent quality and operation costs are considered while reducing $\mathrm{N}_{2} \mathrm{O}$ emissions,

- The control strategy is found to reduce the $\mathrm{N}_{2} \mathrm{O}$ produced by AOB denitrification.

\section{ABSTRACT}

A novel control strategy for achieving low $\mathrm{N}_{2} \mathrm{O}$ emissions and low effluent $\mathrm{NH}_{4}{ }^{+}$concentration is here proposed. The control strategy uses the measurements of ammonium and nitrate concentrations in inlet and outlet of the aerobic zone of a wastewater treatment plant to calculate a ratio indicating the balance among the microbial groups. More specifically, the ratio will indicate if there is a complete nitrification. In case nitrification is not complete, the controller will adjust the aeration level of the plant in order to inhibit the production of $\mathrm{N}_{2} \mathrm{O}$ from $\mathrm{AOB}$ and $\mathrm{HB}$ denitrification. The controller was implemented using the fuzzy logic approach. It was comprehensively tested for different model structures and different sets of model parameters with regards to its ability of mitigating $\mathrm{N}_{2} \mathrm{O}$ emissions for future applications in real wastewater treatment plants. It is concluded that the control strategy is useful for those plants having AOB denitrification 


\section{List of abbreviations and symbols}

\begin{tabular}{|c|c|}
\hline AEC & Average aeration energy consumption \\
\hline $\mathrm{AOB}$ & Ammonia-oxidizing bacteria \\
\hline ASMG1 & Activated Sludge Model for Greenhouse gases $\mathrm{N}^{\mathrm{o}} 1$ \\
\hline BSM2N & Benchmark Simulation Model $\mathrm{n}^{\circ} 2$ for Nitrous oxide \\
\hline $\mathrm{DO}_{\mathrm{SP}}$ & Set point for dissolved oxygen concentration \\
\hline EQI & Effluent Quality Index \\
\hline FLC & Fuzzy-logic control \\
\hline$\eta_{\mathrm{TKN}}$ & TKN removal efficiency \\
\hline$\eta_{\mathrm{TN}}$ & TN removal efficiency \\
\hline HB & Heterotrophic bacteria \\
\hline IAE & Integral Absolute Error \\
\hline ISE & Integral Square Err \\
\hline $\mathrm{k}_{\mathrm{L}} \mathrm{a}$ & Oxygen mass transfer coefficient \\
\hline $\mathrm{K}_{\mathrm{O} 2, \mathrm{AOB}}$ & Oxygen affinity constant for aerobic AOB activity \\
\hline $\mathrm{K}_{\mathrm{O} 2, \mathrm{NOB}}$ & Oxygen affinity constant for NOB activity \\
\hline NOB & Nitrite-oxidizing bacteria \\
\hline $\mathrm{N}_{\text {org,inAER }}$ & Organic Nitrogen in the influent to the aerobic zone \\
\hline PID & Proportional Integrative Derivative \\
\hline Q & Volumetric flow rate \\
\hline RON & Oxygen-to-TKN loading ratio \\
\hline SF & Scaling Factor \\
\hline
\end{tabular}


$\mathrm{S}_{\mathrm{I}} \quad$ Soluble inert organic matter

$\mathrm{S}_{\mathrm{S}} \quad$ Readily biodegradable organic matter

$\mathrm{T} \quad$ Temperature

TKN Total Kjeldahl Nitrogen

TN Total Nitrogen

TV Total Variation

$\mathrm{X}_{\mathrm{I}} \quad$ Particulate inert organic matter

$\mathrm{X}_{\mathrm{P}} \quad$ Particulate products from biomass decay

$\mathrm{X}_{\mathrm{S}} \quad$ Particulate biodegradable organic matter

WWTP Wastewater treatment plant

\section{Introduction}

On-line process control is a tool widely used to automatically manipulate operating conditions of a process in function of measured disturbances with the aim of achieving predefined process performance targets. In wastewater treatment plants (WWTPs), several objectives need to be satisfied. The legal effluent discharge limits and the minimization of the operational costs are some of the most important objectives. There is however an emerging objective which needs to be tackled through the use of on-line process control, i.e. the minimization of emissions of nitrous oxide $\left(\mathrm{N}_{2} \mathrm{O}\right)$. It has in fact been found that the amount of greenhouse gases emitted from WWTPs has increased constantly over the last decades (Fischedick et al., 2014) and, in order to limit the carbon footprint of WWTPs, $\mathrm{N}_{2} \mathrm{O}$ emissions need to be minimized. There are three biological pathways according to which $\mathrm{N}_{2} \mathrm{O}$ is produced in domestic WWTPs: (a) denitrification by ammonia-oxidizing bacteria $(\mathrm{AOB})$, where $\mathrm{AOB}$ use nitrites $\left(\mathrm{NO}_{2}{ }^{-}\right)$and nitric oxides $(\mathrm{NO})$ as electron acceptors for the oxidation of hydroxylamine $\left(\mathrm{NH}_{2} \mathrm{OH}\right)$, an ammonium-to-nitrite oxidation intermediate; (b) incomplete hydroxylamine oxidation, a process originating from the accumulation of hydroxylamine oxidation intermediates such as nitroxyl radicals or NO; and (c) denitrification by heterotrophs (HB), where $\mathrm{N}_{2} \mathrm{O}$ is produced as intermediate of nitrate $\left(\mathrm{NO}_{3}{ }^{-}\right)$and $\mathrm{NO}_{2}^{-}$reduction into dinitrogen gas $\left(\mathrm{N}_{2}\right)$ for the oxidation of organic matter. 
Several full-scale WWTP experiences have been reported in the literature - such as Foley et al. (2010), Daelman et al. (2015), Aboobakar et al. (2013), Ahn et al. (2010) and Stenström et al. (2014) - having identified AOB denitrification as the main pathway producing most of the $\mathrm{N}_{2} \mathrm{O}$ emitted. These results were extensively discussed in Boiocchi et al. (2017). On the other hand, studies such as Ni et al. (2013) and Tumendelger et al. (2014) reported the incomplete $\mathrm{NH}_{2} \mathrm{OH}$ oxidation pathway as the main $\mathrm{N}_{2} \mathrm{O}$ producer, though pointing out as well that $\mathrm{AOB}$ denitrification should not be excluded as potential $\mathrm{N}_{2} \mathrm{O}$ producing pathway in other contexts. These differing findings suggest that specific WWTP design (SRT, configuration, etc...), operation (such as aeration strategy) and influent factors (nitrogen loading, temperature, etc...) promotes different $\mathrm{N}_{2} \mathrm{O}$ production mechanisms. Although both AOB mechanisms should be considered, AOB denitrification is here chosen as the main process to be slowed down through the control strategy for $\mathrm{N}_{2} \mathrm{O}$ emission minimization. This is because relatively more WWTPs have been reported in literature (see e.g. the surveys by Foley et al. (2010) and Ahn et al. (2010) ) suggesting the AOB denitrification process as the dominant $\mathrm{N}_{2} \mathrm{O}$ producer.

Microbiological and experimental experiences have demonstrated that AOB denitrification is triggered by low availability of dissolved oxygen and high availability of nitrites (Peng et al., 2014, 2015). More specifically, low availability of oxygen forces $\mathrm{AOB}$ to use nitrogen oxides as alternative electron acceptors. For example, the experiment by Sun et al. (2014) showed that ensuring oxygen availability in a full-scale WWTP to achieve complete nitrification, i.e. complete conversion of ammonium into nitrate, is the key for minimizing $\mathrm{N}_{2} \mathrm{O}$ emissions. However, the $\mathrm{N}_{2} \mathrm{O}$ minimizing effect of oxygen is only observed until a certain threshold, above which supplying more oxygen does not further reduce the $\mathrm{N}_{2} \mathrm{O}$ production and emissions. On the contrary, excessive oxygen supply may trigger HB-produced nitrite accumulation in the anoxic zone and slow down the HB-mediated $\mathrm{N}_{2} \mathrm{O}$ reduction into $\mathrm{N}_{2}$. Therefore, it is important to accomplish an optimal oxygen level through automatic regulation of the aeration regime with the aim of reducing the $\mathrm{N}_{2} \mathrm{O}$ emissions, which constitutes the objective for this work.

For this reason, the present study focuses on developing an on-line control strategy establishing the optimal oxygen availability in the aerated zone with the aim of preventing $\mathrm{N}_{2} \mathrm{O}$ formation in continuously-aerated WWT systems. The control strategy is based on the following principle identified through a comprehensive sensitivity analysis by Boiocchi et al. (2017): (i) the controlled variable is the measured ratio between nitrate 
generated and ammonium removed in an aerobic zone, indicating the microbiological imbalance between the different microorganisms, (ii) aeration supply is the variable ultimately manipulated in order to maintain a desired balance among microorganisms.

Several control techniques such as model-predictive (MP), Proportional-Integral-Derivative (PID) and fuzzylogic (FL), can be used to implement the above control principle. While MP control in theory can provide optimal control actions, its application to the $\mathrm{N}_{2} \mathrm{O}$ control problem in full-scale plants is currently not very practical since the present $\mathrm{N}_{2} \mathrm{O}$ models are too uncertain to be used for control (Behera et al., 2015). On the other hand, the PID approach is not suitable to deal with multiple control objectives and the highly nonlinear dynamic behaviour typical of WWT processes. While the fuzzy-logic (FL) technique has many parameters to be tuned, it provides a flexible tool that can incorporate both the process non-linearity and the multiple objectives of WWT systems (Cosenza et al., 2014). This is why the fuzzy-logic approach is adopted in this study during the control design.

Once designed, the control strategy performance is implemented and tested on three different modified BSM2 simulation platforms describing three different $\mathrm{N}_{2} \mathrm{O}$ dynamics. To address the benefits of the novel control strategy to WWTPs, the performance is benchmarked against a typical aeration cascade control technique for the maintenance of low effluent ammonium concentration. The performance of the FL controller is further checked against: a) the sensor and actuator noise commonly occurring in WWTPs, and b) model parameter uncertainties.

The manuscript is structured as follows: in Section 2 the design of the control strategy is described, Section 3 shows the implementation and testing of the control strategy, and the results obtained thereby are presented in Section 4. Conclusions and future perspectives are provided in Section 5.

\section{Design of the control strategy}

Following the systematic development of the membership functions used by Boiocchi et al. (2016), the approach to develop the fuzzy-logic control strategy involved the following workflow:

$$
\text { I) Specification of the optimization problem, }
$$

II) Identification of the critical points, 
III) Definition of the membership functions for input and output variables,

IV) Definition of additional design parameters.

104 Each of these workflow steps is explained briefly in the next sections.

\subsection{Specification of the optimization problem}

This task is split up into the following sub-steps:

- Definition of the control objectives,

- Definition of the control structure,

- Definition of the physical constraints,

- Identification of the key scenarios leading the system away from optimality,

- Identification of the relationship between optimization variables and controlled variables.

\section{Definition of the control objectives}

In contrast to what has been done for the controller developed by Boiocchi et al. (2016), the objectives for $\mathrm{N}_{2} \mathrm{O}$ emissions cannot be expressed numerically because - differently from the TN removal efficiency - the minimum amount of $\mathrm{N}_{2} \mathrm{O}$ possibly emitted varies quite a lot from one plant to another according to many operating and design parameters. Instead, the control objectives are here defined qualitatively as follows: "the controller has to establish those generic environmental conditions which give the least $\mathrm{N}_{2} \mathrm{O}$ production and subsequent emission suited for the particular WWTP, while respecting legal effluent $\mathrm{NH}_{4}{ }^{+}$limits". Thus the strategy can potentially be applied for a large number of WWTPs, without the need for strong adaptations to specific cases. These control objectives will be mathematically translated on the basis of the trends of the steady-state $\mathrm{N}_{2} \mathrm{O}$ emission factors and of the effluent ammonium concentration with respect to the oxygento-TKN loading ratio (RON) presented in Figure 1. RON represents the ratio between oxygen supplied and TKN in the influent to the aerated zone of the activated sludge unit of a WWTP, as explained in more detail in Boiocchi et al. (2017) . These simulations were performed with the Benchmark Simulation Model $n^{\circ} 2$ (BSM2) by Jeppsson et al. (2007) extended with the Activate Sludge Model for Greenhouse gases $\mathrm{n}^{\circ} 1$ 
(ASMG1) by Guo and Vanrolleghem (2014). This model includes only AOB denitrification as the AOBmediated $\mathrm{N}_{2} \mathrm{O}$ producing pathway in line with our objective for the controller development (see introduction). Since the controller is based on the assumption that an effective minimization of $\mathrm{N}_{2} \mathrm{O}$ emissions can be achieved by slowing down AOB denitrification, this would enable a better identification of the design parameters of the control technology acting on this process. The testing of the resulting controller will show how this assumption adopted for the control design affects the performance of the controller. For those plants having incomplete $\mathrm{NH}_{2} \mathrm{OH}$ oxidation as main $\mathrm{N}_{2} \mathrm{O}$ producing pathway, the sensitivity analysis should use the model by Ni et al. (2013).

Figure 1 summarizes the so-called "best and worst system operations" identified. The best system operation is found when the minimal $\mathrm{N}_{2} \mathrm{O}$ emission factor is achieved and the effluent ammonium is below the typical legal limit of $4 \mathrm{mg} \mathrm{N} . \mathrm{L}^{-1}$. As can be seen, at RON equal to zero, the $\mathrm{N}_{2} \mathrm{O}$ emission factor is zero. However, this scenario is not considered desirable since the conversion of ammonium is zero as well. On the other hand, for values of RON equal or higher than $5.2 \mathrm{~g}(-\mathrm{COD}) \cdot \mathrm{g}^{-1} \mathrm{TKN}, \mathrm{N}_{2} \mathrm{O}$ is minimized while at the same time the highest ammonium conversion occurs. However, $\mathrm{N}_{2} \mathrm{O}$ production by $\mathrm{HB}$ in the anoxic zone sensibly increases for a load of $5.2 \mathrm{~g}$ (-COD). $\mathrm{g}^{-1} \mathrm{TKN}$, as described in Boiocchi (2016). Although the contribution of HB from the anoxic zone to $\mathrm{N}_{2} \mathrm{O}$ emissions is almost negligible according to the model used, it is still relevant to avoid this scenario due to the uncertainty in the model parameters. As a matter of fact, it can be that for some plants this contribution will emerge to be more relevant than predicted. In view of this, the best system operation is identified for RON equal to 5.2. With regard to the "worst system operation", this is identified to occur according to two different scenarios: (a) excessive oxygen availability, at RON equal to 6 $\left(\mathrm{RON}_{\text {worst,a }}\right)$, and (b) insufficient oxygen availability, at RON equal to 4.8 ( $\left.\mathrm{RON}_{\text {worst, } \mathrm{b}}\right)$. In both cases, the control action will have to be the maximum possible in order to re-establish the system operation to its best as soon as possible. The value at $\mathrm{RON}_{\text {worst,a }}$ was chosen since it was the maximum possible indicating the excessive oxygen supply. The value at $\mathrm{RON}_{\text {worst, } \mathrm{b}}$ was chosen when the curve for the $\mathrm{N}_{2} \mathrm{O}$ emission factor

151 started increasing towards rather high $\mathrm{N}_{2} \mathrm{O}$ emissions. In addition to this, regardless the $\mathrm{N}_{2} \mathrm{O}$ emission

152 factors, the maximum control action will have to be taken when the effluent ammonium is above the typical legal limit of $4 \mathrm{mg} \mathrm{N} \cdot \mathrm{L}^{-1}$. 
Figure 1: (a) $\mathrm{N}_{2} \mathrm{O}$ emission factors, and (b) effluent $\mathrm{NH}_{4}{ }^{+}$concentration against oxygen-to-nitrogen loading ratio (RON) at a temperature of $15^{\circ} \mathrm{C}$ according to the ASMG1.

The control structure is defined to monitor the degree of complete nitrification as follows: If all the ammonium oxidized by AOB in the aerobic zone is converted into nitrate, this indicates that all the AOBproduced nitrites have been oxidized by NOB and not reduced by AOB to produce $\mathrm{N}_{2} \mathrm{O}$. Therefore, the relative ratio of the ammonium consumed by $\mathrm{AOB}$ over the amount of nitrate produced by NOB is used to monitor the extent of nitrite build up which triggers $\mathrm{N}_{2} \mathrm{O}$ emissions from continuously-aerated systems. This ratio between overall nitrate produced and overall ammonium nitrogen depleted in an aerobic zone $\left(R_{\text {NatAmm }}\right)$, expressed in Eqn. (1), is used here as candidate controlled variable.

$$
R_{N a t A m m}=\frac{\left.N O_{3}^{-}\right|_{\text {OUT, } A E R}-\left.N O_{3}^{-}\right|_{I N, A E R}}{\left.N H_{4}^{+}\right|_{I N, A E R}-\left.N H_{4}^{+}\right|_{\text {OUT,AER }}}
$$

Although theoretically the value of $\mathrm{R}_{\mathrm{NatAmm}}$ of 1 represents the right balance between $\mathrm{AOB}$ and NOB, in practice this ratio is expected to be higher due to additional processes such as biomass decay and additional organic nitrogen release. In control applications, the optimal ratio and therefore set point can be computed from open loop simulation, which is done here.

By setting $\mathrm{R}_{\mathrm{NatAmm}}$ at its optimal set point, $\mathrm{N}_{2} \mathrm{O}$ production by $\mathrm{AOB}$ and $\mathrm{HB}$ is expected to be automatically minimized while avoiding wasting aeration energy and inhibiting HB denitrification.

Since the conversion of organic nitrogen into nitrate is sped up by an increased operating temperature, the optimal value for $\mathrm{R}_{\mathrm{NatAmm}}$ is expected to increase in function of operating temperature. To take this into account, temperature adaptation of the set points for $R_{\text {NatAmm }}$ is included using a separate fuzzy-logic module, using the measured influent temperature as single input variable.

176 While keeping $\mathrm{R}_{\text {NatAmm }}$ at its optimal value and thus reducing $\mathrm{N}_{2} \mathrm{O}$ production, it is important to ensure a sustained ammonium conversion with the aim of respecting ammonium effluent limits. For this reason, the 
effluent ammonium concentration is used as additional input to the control system to support taking the decision on the proper control action.

With regard to the manipulated variable used to achieve the control objective, either the air supply, here represented by the oxygen mass transfer coefficient $\left(k_{L} a\right)$, or the oxygen concentration set point $\left(D O_{S P}\right)$ of a Proportional Integral (PI) controller, will be adopted to regulate the oxygen availability in the aerobic zone. It will be evaluated which one of the two manipulated variables is more effective in adapting the oxygen demand to achieve the optimal value of $\mathrm{R}_{\mathrm{NatAmm}}$ and thus reducing $\mathrm{N}_{2} \mathrm{O}$ emissions and keeping low $\left[\mathrm{NH}_{4}{ }^{+}\right]_{\text {eff. }}$. controlled variables $(y)$ around an aerated zone.

$$
\begin{gathered}
\underline{d}=\left[N H_{4, i n}^{+}, S_{S, i n}, T_{i n}, X_{S, i n}, X_{P, i n}, N O_{2, i n}^{-}, N O_{3, i n}^{-}, Q_{i n}, N O_{i n}, N_{2} O_{i n}, N_{2, i n}, X_{I, i n}, S_{I, i n}\right] \\
\underline{x}=\left[N H_{4}^{+}, S_{S}, T, X_{S}, X_{P}, N O_{2}^{-}, N O_{3}^{-}, N O, N_{2} O, N_{2}, X_{I}, S_{I}\right] \\
\underline{y}=\left[R_{N a t A m m}, N H_{4, \text { eff }}^{+}\right] \\
\underline{u}=\left[k_{L} a\right] \text { or }\left[D O_{S P}\right]
\end{gathered}
$$

Based on the two manipulated variables shown in Eqn. (5), two generic control structures are implemented in an aerobic zone of a WWTP for the minimization of $\mathrm{N}_{2} \mathrm{O}$ emissions, as shown in Figure 2. As can be seen, the measured ammonium and nitrate nitrogen concentration in the inlet and outlet of the aerated zone are used for the calculation of $\mathrm{R}_{\mathrm{NatAmm}}$. The influent temperature to the system is used to update the set point for $R_{\text {NatAmm }}\left(R_{\text {NatAmm,SP }}\right)$ through a fuzzy-logic module. The difference between $R_{\text {NatAmm,SP }}$ and $R_{N a t A m m}$, along with the effluent $\mathrm{NH}_{4}{ }^{+}$concentration, is given as input to the fuzzy-logic control, which infers the unitary variation for the manipulated variable (either $\Delta_{U} k_{L}$ a or $\Delta_{U} \mathrm{DO}_{S P}$ ). This variation is named unitary because it is comprised between a minimal value of -1 and a maximal value of +1 . This quantity therefore forms an indicator of whether the manipulated variable has to be increased or decreased. To attribute a physical dimension to this quantity, a scaling factor (either $\mathrm{SF}_{\mathrm{kLa}}$ or $\mathrm{SF}_{\mathrm{DOsp}}$ ), of the same order of magnitude as the nominal value of the corresponding manipulated variable, is multiplied with this quantity. By summing up these unit variations in time, the variations $\Delta \mathrm{k}_{\mathrm{L}}$ a or $\Delta \mathrm{DO}_{\mathrm{SP}}$ constitute the difference between the value of the actual manipulated variable and its corresponding nominal value (either $\mathrm{k}_{\mathrm{L}} \mathrm{a}_{\text {nom }}$ or $\mathrm{DO}_{\mathrm{SP} \text {,nom }}$ ). The exact 
setting of the manipulated variable is thus known by adding its corresponding nominal value. In the configuration where the set point for dissolved oxygen is used as manipulated variable (Figure $2 \mathrm{~b}$ ), the $\mathrm{DO}_{\mathrm{SP}}$ inferred through the fuzzy-logic controller is then used in a PI controller exploiting the DO measurements.

Figure 2: Control system implementation using as manipulated variable: (a) oxygen mass transfer coefficient, and (b) set point of dissolved oxygen concentration.

Considerations about the expected effect of such a control strategy on the $\mathrm{N}_{2} \mathrm{O}$ dynamics contribution from heterotrophs and the reasons for not choosing nitrous oxide and/or nitrites as controlled variables are reported in Appendix A1.

\section{Definition of the physical constraints}

In line with the definition of the BSM2, the $\mathrm{k}_{\mathrm{L}} \mathrm{a}$ is kept between 0 and $360 \mathrm{~d}^{-1}$. The values for DO are kept between 0.5 and $3 \mathrm{mg}(-\mathrm{COD}) \cdot \mathrm{L}^{-1}$ while the oxygen concentration in the stream recycled to the anoxic zone is kept between 0.5 and $1 \mathrm{mg}(-\mathrm{COD}) \cdot \mathrm{L}^{-1}$. The choice of the minimal oxygen concentration equal to $0.5 \mathrm{mg}(-$ COD). $\mathrm{L}^{-1}$ was taken to prevent compromising biomass settleability. The maximum oxygen concentration of $3 \mathrm{mg}(-\mathrm{COD}) \cdot \mathrm{L}^{-1}$ was chosen to avoid wasting aeration energy without improving process performance. It is also well-known that WWTPs working with continuous aeration do not usually surpass this threshold (Holenda et al., 2008; Tallec et al., 2006, 2008). The upper limit in the stream carried to the anoxic zone (1 mg (-COD). $\left.\mathrm{L}^{-1}\right)$ was chosen to avoid direct oxygen inhibition of HB denitrification, which causes a higher amount of non-oxidized organic carbon to be fed in the aerobic zone. This in turn has been found to remove oxygen from NOB (due to competition with heterotrophs), where the NOB play a very important role in avoiding nitrite accumulation.

The physical constraints on the controlled variables $\mathrm{R}_{\mathrm{NatAmm}}$ and $\left[\mathrm{NH}_{4}{ }^{+}\right]_{\text {eff }}$ are expressed in Eqn. (6). As can be seen, both of them have a lower limit of zero. The upper limit for $\mathrm{R}_{\mathrm{NatAmm}}$ is given by the sum of the unit, which is achieved when all the influent ammonium is converted into nitrate, and the ratio between the total amount of influent organic nitrogen $\left(\mathrm{N}_{\text {org,inAER }}\right)$ and the amount of influent ammonium consumed. As a matter of fact, as previously described, the organic nitrogen influent to the aerobic zone can be, under high oxygenation regimes, quickly hydrolysed and ammonified, oxidized into nitrite and finally converted into nitrate by NOB. Thus $\mathrm{R}_{\mathrm{NatAmm}}$ can have values higher than unity. $\mathrm{TKN}_{\mathrm{in}, \mathrm{AER}}$ is the Total Kjeldahl Nitrogen in 
the influent to the aerobic zone which is used to represent the maximal amount of effluent ammonium that could potentially be released. As a matter of fact, at rather poor oxygen levels, the influent ammonium is not consumed and, in addition, the influent organic nitrogen is hydrolysed and ammonified.

$$
\left\{\begin{array}{c}
0 \leq R_{\text {NatAmm }} \leq\left(1+\frac{N_{\text {org }, \text { inAER }}}{\Delta N H_{4}^{+}}\right) \\
0 \leq\left[N H_{4}^{+}\right]_{\text {eff }} \leq T K N_{\text {inAER }}
\end{array}\right.
$$

All disturbances and state variables other than the oxygen concentrations in the aerobic zone can have theoretical values comprised between 0 and $<+\infty$.

Identification of the key scenarios leading the system away from the control objectives

The best system operation is achieved when both $\mathrm{N}_{2} \mathrm{O}$ emissions are minimized and effluent ammonium concentration respects the legal effluent limits. On the other hand, situations when $\mathrm{N}_{2} \mathrm{O}$ emissions are not minimized and/or effluent ammonium concentrations do not respect legal effluent limits are considered to represent a biological system that is away from optimality. Table 1 summarizes all of these conditions. The parameters used as indicators of the proximity of the system to the control objectives are: (a) the net $\mathrm{N}_{2} \mathrm{O}$ produced by $\mathrm{AOB}$ and $\mathrm{HB}$ in the aerobic zone, (b) the net $\mathrm{N}_{2} \mathrm{O}$ produced by $\mathrm{HB}$ in the anoxic zone, and (c) the effluent ammonium nitrogen concentration.

Table 1: Summary of scenarios leading the biological system away from optimality.

Differently from Boiocchi et al. (2016), in this case study the relationship between control objectives and controlled variables is not calculated on the basis of mathematical expressions but is qualitatively derived from the steady state results achieved during the sensitivity analysis described in Boiocchi et al. (2017). This approach is chosen due to the high degree of uncertainty linked to the calculation of $\mathrm{N}_{2} \mathrm{O}$ emissions, where several biological and physical processes are involved.

Figure 3 shows the relationships between $\mathrm{N}_{2} \mathrm{O}$ emission factors and RON and the relationships between 
the scenario at temperature of $15^{\circ} \mathrm{C}$, will be used to derive the critical points for $\mathrm{R}_{\mathrm{NatAmm}}$. Figures $3 \mathrm{a}$ and $3 \mathrm{c}$ will be used to build up the fuzzy-logic module adjusting the set points for $\mathrm{R}_{\mathrm{NatAmm}}$ in function of influent temperature.

Figure 3: Steady-state $\mathrm{N}_{2} \mathrm{O}$ emission factors and $\mathrm{R}_{\mathrm{NatAmm}}$ in function of $\mathrm{RON}$ at the operating

In real applications, historical measurements of nitrogen concentrations and $\mathrm{N}_{2} \mathrm{O}$ emissions could be used

to be achieved with the aim of having a balanced activity between AOB and NOB should not go below unity in any case. On the other hand, the value of $R_{\mathrm{NatAmm}}$ indicating the worst system operation due to excessive oxygen supply could be more subjective and case-specific.

\subsection{Identification of the critical points for the controlled variables}

Critical points for the controlled variable $\mathrm{R}_{\mathrm{NatAmm}}$ are retrieved from Figure $3 \mathrm{~b}$. As can be seen, the value of $\mathrm{R}_{\mathrm{NatAmm}}$ minimizing $\mathrm{N}_{2} \mathrm{O}$ emissions is equal to 1.2 . The reasons for having an optimal point of $\mathrm{R}_{\mathrm{NatAmm}}$ higher than the theoretical value of 1 are described in Appendix A2.

However, to incorporate potential error in the measurements, negative and positive variations of 0.05 around this set point were considered to be completely acceptable. The value of $\mathrm{R}_{\mathrm{NatAmm}}$ which describes the socalled "worst system operation" due to insufficient oxygen availability is found to be equal to 1 while the value of $R_{\text {NatAmm }}$ which describes the same operation of the system due to excessive oxygen supply is found

274 With regards to the effluent ammonium concentration, although a typical legal limit for effluent ammonium 275 concentrations is $4 \mathrm{mg} \mathrm{N} . \mathrm{L}^{-1}$, in order to stay on the safe side, it was decided for the controller to identify 276 values higher than $2 \mathrm{mg} \mathrm{N} . \mathrm{L}^{-1}$ as the worst system operation requiring maximal control action. Optimal values for $\left[\mathrm{NH}_{4}{ }^{+}-\mathrm{N}\right]_{\text {eff }}$ are chosen to be equal or lower than $1.5 \mathrm{mg} \mathrm{N} \cdot \mathrm{L}^{-1}$. 
Eqns. (7-10) express the critical points for the vector of controlled variables identified for each system operation, optimal and worst, for each scenario of Table 1 .

$U B$ for OPTIMAL SYSTEM OPERATION $\Rightarrow \underline{y}_{U B, O P T}=\left[\begin{array}{ll}1.2 & 0\end{array}\right]$

$$
\text { LB for OPTIMAL SYSTEM OPERATION } \Rightarrow\left\{\begin{array}{l}
y_{L B, O P T}^{1}=\left[\begin{array}{ll}
1.2 & 1.5
\end{array}\right] \\
y_{L B, O P T}^{2}=\left[\begin{array}{ll}
1.25 & 0
\end{array}\right] \\
y_{L B, O P T}^{3}=\left[\begin{array}{ll}
1.15 & 0
\end{array}\right] \\
y_{L B, O P T}^{4}=\left[\begin{array}{ll}
1.25 & 1.5
\end{array}\right] \\
y_{L B, O P T}^{5}=\left[\begin{array}{ll}
1.15 & 1.5
\end{array}\right]
\end{array}\right.
$$

$$
\text { UB for WORST SYSTEM OPERATION } \Rightarrow\left\{\begin{array}{c}
y_{U B, W O R S T}^{1}=\left[\begin{array}{ll}
1.2 & 2
\end{array}\right] \\
y_{L B, O P T}^{2}=\left[\begin{array}{ll}
1.4 & 0
\end{array}\right] \\
y_{L B, O P T}^{3}=\left[\begin{array}{ll}
1 & 0
\end{array}\right] \\
y_{L B, O P T}^{4}=\left[\begin{array}{ll}
1.4 & 2
\end{array}\right] \\
y_{L B, O P T}^{5}=\left[\begin{array}{ll}
1 & 2
\end{array}\right]
\end{array}\right.
$$

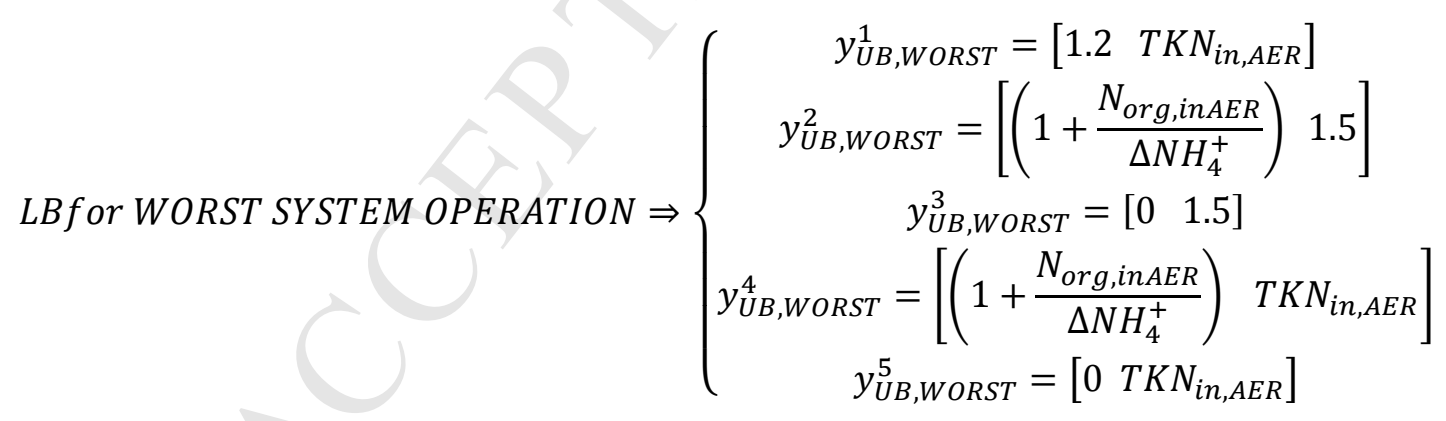

\subsection{Definition of the membership functions for input and output variables}

The first step in the definition of the membership functions (MFs) for the input variables consists of the identification of the key CVs whose variation clearly indicates the moving away from optimality. In this case, both $\mathrm{R}_{\mathrm{NatAmm}}$ and effluent $\mathrm{NH}_{4}{ }^{+}-\mathrm{N}$ are key for the identification of the different scenarios presented in Table 1. 
With regards to the shape of the membership functions for input and output variables, triangular and trapezoidal shapes were chosen for the sake of simplicity.
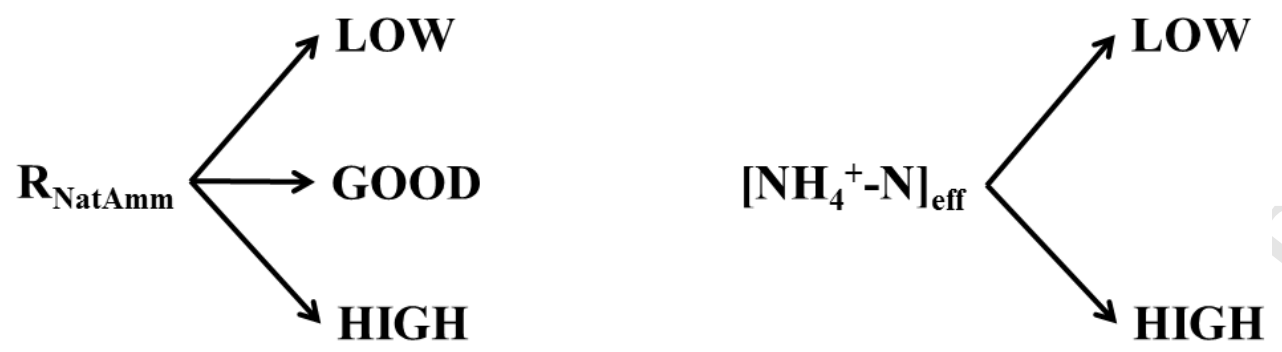

The last step consists in the assignment of the degree of membership to fuzzy sets previously identified for each numerical value of $\mathrm{R}_{\mathrm{NatAmm}}$ and $\left[\mathrm{NH}_{4}{ }^{+}-\mathrm{N}_{\text {eff }}\right]$. A degree of membership to the identified fuzzy sets equal to 1 will be assigned to the critical points defined in subsection 2.2 as expressed in Eqns. (10-13). A degree of membership equal to 0 to the other fuzzy sets will be assigned to the same critical points.

$$
\begin{gathered}
\text { UB for OPTIMAL SYSTEM OPERATION } \Rightarrow\left\{\begin{array}{c}
\left(R_{\text {NatAmm }}\right)_{G O O D}=1.2 \\
\left(N H_{4, e f f}^{+}\right)_{G O O D}=0
\end{array}\right. \\
\text { LB for OPTIMAL SYSTEM OPERATION } \Rightarrow\left\{\begin{array}{c}
\left(R_{\text {NatAmm }}\right)_{G O O D}=1.15 \text { and } 1.25 \\
\left(N H_{4, \text { eff }}^{+}\right)_{G O O D}=1.5
\end{array}\right. \\
\text { UB for WORST SYSTEM OPERATION } \Rightarrow\left\{\begin{array}{c}
\left(R_{\text {NatAmm }}\right)_{L O W}=1 \\
\left(R_{\text {NatAmm }}\right)_{H I G H}=1.4 \\
\left(N H_{4, \text { eff }}^{+}\right)_{\text {HIGH }}=2
\end{array}\right.
\end{gathered}
$$




$$
\text { LB for WORST SYSTEM OPERATION } \Rightarrow\left\{\begin{array}{c}
\left(R_{\text {NatAmm }}\right)_{L O W}=0 \\
\left(R_{\text {NatAmm }}\right)_{H I G H}=\left(1+\frac{N_{\text {org }, \text { inAER }}}{\Delta N H_{4}^{+}}\right) \\
\left(N H_{4, \text { eff }}^{+}\right)_{H I G H}=T K N_{\text {in, AER }}
\end{array}\right.
$$

Figure 4 shows the resulting membership functions for $\mathrm{R}_{\mathrm{NatAmm}}$ and $\left[\mathrm{NH}_{4}{ }^{+} \mathrm{N}\right]_{\text {eff }}$.

As disclosed in the Section "control structure definition", the difference between the $R_{\mathrm{Nat} A m m, S P}$ and $\mathrm{R}_{\mathrm{Nat} A m m}$

$\left(E_{R N a t A m m}=R_{N a t A m m, S P}-R_{N a t A m m}\right)$, and not $R_{\text {NatAmm }}$, is used as input variable. This makes the external change of the set point easier, which is in this case needed to incorporate the temperature effect. To obtain the membership functions for $E_{\mathrm{RNatAmm}}$ from the ones for $\mathrm{R}_{\mathrm{NatAmm}}$, the numerical values of the membership function (on the $\mathrm{x}$-axis) in Figure $4 \mathrm{a}$ will be multiplied by -1 . Then the value of 1.2 will be added, which is the set point at $15^{\circ} \mathrm{C}$ for $\mathrm{R}_{\mathrm{NatAmm}}$. The membership functions shown in Figure 5 are thereby obtained as a result.

Similarly to Boiocchi et al. (2016), the membership functions for the unitary variation of $\mathrm{k}_{\mathrm{L}}$ a or of $\mathrm{DO}_{\mathrm{SP}}$ are defined such that the maximum positive value that this quantity will get is +1 and the maximum negative value that this quantity will get is -1 . Taking into account the Center-of-Area as the chosen defuzzification

\section{Fuzzy logic module for temperature adaptation}

As previously mentioned, the set point for $\mathrm{R}_{\mathrm{NatAmm}}$ is adapted in function of the temperature. This is because temperature increases the amount of influent organic nitrogen overall converted into nitrate and thus it sensibly increases the optimal set point for $\mathrm{R}_{\mathrm{NatAmm}}$ at which $\mathrm{N}_{2} \mathrm{O}$ emissions are minimized. The present 
functions were decided on the basis of the values of $\mathrm{R}_{\mathrm{NatAmm}}$ minimizing $\mathrm{N}_{2} \mathrm{O}$ emissions at the three different temperatures from Figure 3. Specifically, the set points in Table 2 were found.

Table 2: Set points for $\mathrm{R}_{\mathrm{NatAmm}}$ in function of temperature.

Extrapolating, the $\mathrm{R}_{\mathrm{NatAmm}, \mathrm{SP}}$ for a temperature of $5^{\circ} \mathrm{C}$ was assumed to be 1 while the set point for a temperature of $25^{\circ} \mathrm{C}$ was assumed to be 1.6 .

Choosing as default defuzzification method the Center-of-Area method, the membership functions for its input and output variables shown in Figure 7 were designed.

Figure 7: (a) Membership functions for the influent temperature, and (b) membership functions for

$$
\mathrm{R}_{\mathrm{NatAmm}, \mathrm{SP}} \text {. }
$$

\subsection{Implementation of the linguistic rules}

The following look-up table (Table 3 ) shows the IF-THEN linguistic rules connecting the inputs $\left(\mathrm{E}_{\mathrm{RNatAmm}}\right.$ and the effluent ammonium nitrogen concentration) to the output variable $\left(\Delta_{\mathrm{U}} \mathrm{k}_{\mathrm{L}}\right.$ a or $\Delta_{\mathrm{U}} \mathrm{DO}$ SP $)$. As can be noted, when $\left[\mathrm{NH}_{4}{ }^{+}-\mathrm{N}\right]_{\text {eff }}$ is found to belong to the fuzzy set "HIGH", the controller increases the manipulated variable, regardless of the value of $\mathrm{E}_{\mathrm{RNatAmm}}$. Otherwise, the controller will: (a) increase the oxygen availability if $\mathrm{E}_{\mathrm{RNatAmm}}$ belongs to the fuzzy set "HIGH" (i.e. when $\mathrm{R}_{\mathrm{NatAmm}}$ is lower than the set point), which indicates a suboptimal NOB activity rate, or (b) decrease it if $\mathrm{E}_{\mathrm{RNatAmm}}$ belongs to the fuzzy set "LOW" (i.e. when $\mathrm{R}_{\mathrm{NatAmm}}$ is higher than the set point), which indicates waste of oxygen supply, enhancement of $\mathrm{N}_{2} \mathrm{O}$ production by $\mathrm{HB}$ in the anoxic zone and worsening of effluent quality. If both the effluent $\mathrm{NH}_{4}{ }^{+}$and $\mathrm{E}_{\mathrm{RNatAmm}}$ belong to the fuzzy set "GOOD", no control action is taken.

Table 3: Look-up table for the linguistic rules linking $\mathrm{E}_{\mathrm{RNatAmm}}$ and $\left(\mathrm{NH}_{4}{ }^{+}\right)_{\text {eff }}$ to $\Delta_{\mathrm{U}} \mathrm{MV}$ (either $\Delta_{\mathrm{U}} \mathrm{k}_{\mathrm{L}}$ a or

$$
\left.\Delta_{\mathrm{U}} \mathrm{DO}_{\mathrm{SP}}\right)
$$

The linguistic rules for the temperature adaptation fuzzy-logic module are shown in Table 4.

Table 4: Linguistic rules linking the temperature to $\mathrm{R}_{\mathrm{NatAmm}, \mathrm{SP}}$. 
The additional design parameters to be decided were the implication and the aggregation method. Correlation-minimum was chosen as the implication method whereas disjunctive was chosen as the aggregation method.

The scaling factor used for the controller was chosen to be equal to or below the difference between the saturation limit for the manipulated variable used and its nominal value.

\section{Controller implementation and performance evaluation}

Once designed, the control strategy was implemented and tested in the following three benchmark simulation models: the Benchmark Simulation Model $\mathrm{n}^{0} 2$ for Nitrous oxide a (BSM2Na), b (BSM2Nb) and c (BSM2Nc). These three models were developed by using respectively the ASMG1, the two-pathway model by Pocquet et al. (2016) and the two pathway model by Domingo-Felez and Smets (2016) for the description of the biological processes in the mainstream activated sludge unit of the BSM2. Therefore, the benchmark simulation models obtained thereby describe different $\mathrm{N}_{2} \mathrm{O}$ production dynamics. More specifically, the BSM2Na describes $\mathrm{N}_{2} \mathrm{O}$ production during $\mathrm{HB}$ and $\mathrm{AOB}$ denitrification, but not during the incomplete oxidation of hydroxylamine $\left(\mathrm{NH}_{2} \mathrm{OH}\right)$, while the $\mathrm{BSM} 2 \mathrm{Nb}$ and the BSM2Nc incorporate additionally the $\mathrm{N}_{2} \mathrm{O}$ production during the incomplete $\mathrm{NH}_{2} \mathrm{OH}$ oxidation but according to different model equations and assumptions. HB denitrification and NOB activity are modelled the same for all three models. Although the models by Pocquet et al. (2016) and Domingo-Felez and Smets (2016) were not calibrated with full-scale plant data, these two are the only models available in the literature including both the two AOB-mediated $\mathrm{N}_{2} \mathrm{O}$ producing pathways. The only two works published regarding $\mathrm{N}_{2} \mathrm{O}$ model calibrations with full-scale WWTP data are the one by Ni et al. (2013) and by Spérandio et al. (2016). None of the models provided in these works includes both the $\mathrm{N}_{2} \mathrm{O}$ production pathways by AOB. This is because identification of the rates of these two pathways with full-scale plant data is very hard and the hydraulics of full-scale WWTPs is intrinsically much more difficult to model compared to lab-scale reactors (Sin et al., 2008). Even in case a 
model was able to accurately describe full-scale measurements, it would be only valid for the particular WWTP used for the calibration and a lot of uncertainties in the model parameters and in the dominant $\mathrm{N}_{2} \mathrm{O}$ producing pathway would still remain when applying the model for other WWTP configurations with different operation and influent composition (Sin et al., 2009). On the contrary, the aim of the control testing performed in this work is to evaluate the controller robustness for a wider range of WWTPs. In fact, as a consequence of the different $\mathrm{N}_{2} \mathrm{O}$ modelling approaches by Domingo-Felez and Smets (2016), Guo and Vanrolleghem (2014) and Pocquet et al. (2016), the three benchmark models predict $\mathrm{N}_{2} \mathrm{O}$ dynamics differently (see Boiocchi (2016)), which will enable identifting the range of WWTPs where the controller could be successfully applied, and also serves to demonstrating the general applicability of the proposed controller.

A more detailed description of the three benchmark simulation models and how they were developed is given in Boiocchi (2016) while Appendix A3 in Supplementary Material (SI) will provide a description of the structures and default parameter values used for the BSM2Na, BSM2Nb and BSM2Nc. Figure 8 shows the implementation of both the regulatory and the cascade control strategy in the BSM2 layout.

Figure 8: (a) Implementation of the regulatory control strategy, and (b) implementation of the cascade control strategy.

The testing and evaluation procedure will be performed as suggested by Jeppsson et al. (2007). More specifically, the performance criteria used to evaluate the control strategies are summarized in Appendix A4 in the SI, including also the algebraic equations used for their calculation.

For each simulation model, the evaluation criteria will be calculated for the novel closed-loop configurations and compared against the ones obtained for a reference scenario. The latter is identified for each of the three benchmark simulation models through the implementation of a cascade controller regulating the set point of the oxygen concentrations in the three aerobic tanks on the basis of the effluent ammonium concentration according to a PI approach (see Appendix A5 in SI for this configuration). In a next instance, sensor and actuator dynamics are introduced using the sensor and actuator models given by Alex et al. (2008). More specifically, the continuous sensors of type A, working without delay, were chosen for temperature and oxygen concentrations while sensors type B1 (photometric with normal filtration) were included for the 
measurements of ammonium and nitrate concentrations. Type-A actuators were used for the manipulation of the oxygen mass transfer coefficients. Appendix A6 in SI shows the resulting deviations from the actual values imposed for all measured variables.

Finally, the sensitivity of the controller with respect to model parameter variation is analysed. Therefore, the cascade configuration of the controller is simulated on the BSM2Na by varying the oxygen affinity constants for the aerobic activity of $\mathrm{AOB}$ and $\mathrm{NOB}\left(\mathrm{K}_{\mathrm{O} 2, \mathrm{AOB}}\right.$ and $\mathrm{K}_{\mathrm{O} \text {, NOB }}$, respectively) according to various values estimated in the literature. The reason for focusing the sensitivity analysis of the controller on these two affinity constants is due to the fact that one of the basic controller ideas consists of triggering the activity of NOB over the one of AOB by increasing oxygen availability. This is because it was found that NOB are more limited by low oxygen concentrations than $\mathrm{AOB}$ and increasing the oxygenation would enhance the uptake of AOB-produced nitrite by $\mathrm{NOB}$ and thereby prevent $\mathrm{N}_{2} \mathrm{O}$ formation. The fact that NOB are more oxygen-limited than $\mathrm{AOB}$ translates to a higher value of $\mathrm{K}_{\mathrm{O} \text {, NOB }}$ than $\mathrm{K}_{\mathrm{O} \text {, AOB }}$ estimated by Hiatt and Grady (2008). Nevertheless, the relationship between $\mathrm{K}_{\mathrm{O} \text {, NOB }}$ and $\mathrm{K}_{\mathrm{O} 2, \mathrm{AOB}}$ is still uncertain. In fact, although there is a trend in the literature to estimate $\mathrm{K}_{\mathrm{O} 2 \text {,АОВ }}$ with lower values than $\mathrm{K}_{\mathrm{O} \text {, NOB }}$ as clearly shown in Guisasola et al. (2005), there are a few other studies which have estimated values for $\mathrm{K}_{\mathrm{O} \text {, } \mathrm{AOB}}$ higher than $\mathrm{K}_{\mathrm{O} \text {, NOB }}$ (Manser et al., 2005; Picioreanu et al., 2016). The difference in the respective value of these two constants can be addressed to: different species composition of $\mathrm{AOB}$ and NOB, floc size, temperature, size of the colonies of AOB and NOB, spatial distribution of AOB and NOB (Picioreanu et al., 2016). All of these aspects, which are not considered explicitly, may hinder the good performance of the present control strategy.

\section{Results}

In this section, the simulation results obtained using the BSM2Na, BSM2Nb and BSM2Nc are presented and discussed. The control strategies tested and benchmarked are:

1) $\mathrm{NH}_{4}{ }^{+}$cascade controller, using directly the set point for dissolved oxygen $\left(\mathrm{DO}_{\mathrm{SP}}\right)$ as manipulated variable $(C S 1)$ using $1.5 \mathrm{mg} \mathrm{N} . \mathrm{L}^{-1}$ as set point for the effluent ammonium nitrogen (i.e. the reference control strategy),

2) $\mathrm{R}_{\mathrm{NatAmm}}$ and $\mathrm{NH}_{4}{ }^{+}$regulatory controller, using directly $\mathrm{k}_{\mathrm{L}}$ a as manipulated variable (CS2), 
3) $\mathrm{R}_{\mathrm{NatAmm}}$ and $\mathrm{NH}_{4}{ }^{+}$cascade controller, using directly the set point for dissolved oxygen $\left(\mathrm{DO}_{\mathrm{SP}}\right)$ as manipulated variable $(C S 3)$,

4) Control strategy $C S 3$ with sensor and actuator noise added (CS4).

Section 4.1 will be analysing the $\mathrm{N}_{2} \mathrm{O}$ dynamics, Section 4.2 will be focusing on the effluent quality, Section 4.3 will be discussing the energy consumption linked to aeration, and finally in Section 4.4 the sensitivity of the controller to specific model parameters will be analysed.

\subsection{Control performance on the $\mathrm{N}_{2} \mathrm{O}$ emissions}

Table 5 show the emission factors for $\mathrm{N}_{2} \mathrm{O}, \mathrm{R}_{\text {NatAmm }}$, and the $\mathrm{N}_{2} \mathrm{O}$ contributions by the different pathways according to the BSM2Na, BSM2Nb and BSM2Nc, respectively. The Integral Absolute Error and the Integral Square Error for $\mathrm{R}_{\mathrm{NatAmm}}$ are included as well in order to evaluate how the tracking of the set point for $\mathrm{R}_{\mathrm{NatAmm}}$ affects the $\mathrm{N}_{2} \mathrm{O}$ emissions. The total variation of the $\mathrm{k}_{\mathrm{L}} \mathrm{a}$ is considered to include the aggressiveness of the control response.

As can be deduced by comparing the results of CS2 and CS3 against the reference configuration CS1 using the BSM2Na and BSM2Nc, the novel controller is able to drastically reduce the average rate of AOB denitrification by increasing the average value of $\mathrm{R}_{\mathrm{NatAmm}}$. More specifically, as the tracking of the set point for $\mathrm{R}_{\mathrm{NatAmm}}$ - indicated by the IAE and the ISE - improves, the reduction of the amount of $\mathrm{N}_{2} \mathrm{O}$ produced by AOB increases. A contextual decrease in the average amount of $\mathrm{N}_{2} \mathrm{O}$ consumed by $\mathrm{HB}$ can also be observed. This can be largely assigned to the overall lower $\mathrm{N}_{2} \mathrm{O}$ accumulation in the liquid phase, which in turn slows down the last $\mathrm{HB}$ denitrification reduction step. Since the decrease of $\mathrm{N}_{2} \mathrm{O}$ produced by AOB is more than the decrease of $\mathrm{N}_{2} \mathrm{O}$ consumed by $\mathrm{HB}$, both the total $\mathrm{N}_{2} \mathrm{O}$ emitted per unit of influent TKN $\left(\mathrm{N}_{2} \mathrm{O}_{e f l}\right)$ and the total $\mathrm{N}_{2} \mathrm{O}$ emissions per unit of TKN removed $\left(\mathrm{N}_{2} \mathrm{O}_{e f 2}\right)$ have been drastically reduced in the BSM2Na and BSM2Nc. The fact that also $\mathrm{N}_{2} \mathrm{O}$ emissions per unit of TKN removed diminished demonstrates the fact that $\mathrm{N}_{2} \mathrm{O}$ has not been reduced by lowering the overall TKN conversion, but by reducing the rates of those specific processes producing it. 
With regard to the $\mathrm{BSM} 2 \mathrm{Nb}$, it has to be noted first that the model has incomplete $\mathrm{NH}_{2} \mathrm{OH}$ oxidation as the main $\mathrm{N}_{2} \mathrm{O}$ producing pathway. As can be noted, the control strategy is able to decrease the amount of $\mathrm{N}_{2} \mathrm{O}$ produced according to the AOB denitrification and incomplete $\mathrm{NH}_{2} \mathrm{OH}$ oxidation pathways. The ability of the controller in reducing the amount of $\mathrm{N}_{2} \mathrm{O}$ produced by this last pathway can be attributed to the fact that the controller aims at achieving complete nitrification, which means that accumulation of intermediates like $\mathrm{NH}_{2} \mathrm{OH}$ can be suppressed as well. Nevertheless, the reduction of $\mathrm{N}_{2} \mathrm{O}$ consumption by HB with CS2 and $\mathrm{CS} 3$ is larger than the overall reduction of $\mathrm{N}_{2} \mathrm{O}$ produced by the AOB pathways. This can be ascribed to the fact that the control strategies $C S 2$ and $C S 3$ need to increase the oxygen supply more to achieve complete nitrification than in the other models, due to the relevance of the incomplete $\mathrm{NH}_{2} \mathrm{OH}$ oxidation pathway. By doing so, the stripping of $\mathrm{N}_{2} \mathrm{O}$ is triggered and $\mathrm{HB}$ have less chance to reduce $\mathrm{N}_{2} \mathrm{O}$ into $\mathrm{N}_{2}$. As a consequence of this, $\mathrm{N}_{2} \mathrm{O}$ emissions are slightly higher when $C S 2$ and $C S 3$ are applied compared to the case when the $\mathrm{NH}_{4}{ }^{+}$cascade controller is applied $(\mathrm{CS} I)$. However, it should also be noted that the discrepancies are marginal, which means that the novel controllers do not drastically reduce the performance of the plant. The results also suggest that the present controllers should not be used for those plants where the incomplete $\mathrm{NH}_{2} \mathrm{OH}$ oxidation is the main $\mathrm{N}_{2} \mathrm{O}$ producing process.

\section{Adaptability to temperature changes}

The capability of the controller to adapt to temperature variations is checked by observing Figure 9, showing the dynamics of the $\mathrm{N}_{2} \mathrm{O}$ production in the aerobic zone by the different processes and the total amount of $\mathrm{N}_{2} \mathrm{O}$ emitted as predicted by the BSM2Nc for strategies CS1, CS2 and CS3. As can be observed from the results with $C S 1, \mathrm{~N}_{2} \mathrm{O}$ emissions (Figure 9a) are in phase with $\mathrm{N}_{2} \mathrm{O}$ produced by AOB (Figure 9b). More specifically, as the temperature increases, $\mathrm{N}_{2} \mathrm{O}$ production by $\mathrm{AOB}$ increases and $\mathrm{N}_{2} \mathrm{O}$ emissions follow the same trend. The behaviour of $\mathrm{AOB}$ associated $\mathrm{N}_{2} \mathrm{O}$ production is to be attributed to the balance between the aerobic growth of AOB and the aerobic growth by NOB. According to Hellinga et al. (Hellinga et al., 1999), NOB growth has a disadvantage compared to the growth of AOB as temperature increases. This is in fact one of the reasons why the nitritation systems, like the SHARON, are able to work efficiently. As a matter of fact, by keeping the operating temperatures high $\left(30-35^{\circ} \mathrm{C}\right)$, NOB can be washed out in such systems. In activated sludge systems like the one considered here, this behaviour leads to higher nitrite accumulation at 
warm temperatures (see Figure 9c) which, in turn, triggers $\mathrm{AOB}$ denitrification and, consequently, $\mathrm{N}_{2} \mathrm{O}$ emissions. From Figure $9 \mathrm{~d}$ it can be noted that, similarly to AOB denitrification, HB-mediated $\mathrm{N}_{2} \mathrm{O}$ production (i.e. the third $\mathrm{HB}$ denitrification step) is high when temperature increases due to higher availability of AOB-produced nitrites. When the novel controllers are implemented, nitrite accumulation is drastically reduced in summer, which in turn slows down AOB denitrification. Similarly, the $\mathrm{N}_{2} \mathrm{O}$ produced by $\mathrm{HB}$ is reduced drastically by $C S 2$ and $C S 3$ (see Figure 9d). Nevertheless, the consumption of $\mathrm{N}_{2} \mathrm{O}$ by $\mathrm{HB}$ during the last reduction step is reduced (see Figure 9e). Overall, the net $\mathrm{N}_{2} \mathrm{O}$ production by $\mathrm{HB}$ in the aerobic zone is always negative (see Figure 9f), which means that the amount of $\mathrm{N}_{2} \mathrm{O}$ consumed by $\mathrm{HB}$ is higher than the amount of $\mathrm{N}_{2} \mathrm{O}$ produced by $\mathrm{HB}$, and therfeore a fraction of AOB-produced $\mathrm{N}_{2} \mathrm{O}$ is consumed by $\mathrm{HB}$. This overall $\mathrm{N}_{2} \mathrm{O}$ consumption by $\mathrm{HB}$ decreases when the controllers are implemented. This fact can be explained by the lower availability of $\mathrm{N}_{2} \mathrm{O}$ in the liquid phase partly due to lower $\mathrm{AOB}$ denitrification and partly due to higher $\mathrm{N}_{2} \mathrm{O}$ stripping. Nevertheless, the overall $\mathrm{N}_{2} \mathrm{O}$ emitted is reduced through implementation of the controllers.

Exceptionally, for cold temperatures the regulatory controller (CS2) is not able to optimize the oxygen supply to reduce the nitrite accumulation, compared to the reference scenario given by CSI. This led to higher $\mathrm{N}_{2} \mathrm{O}$ production by $\mathrm{AOB}$ and $\mathrm{HB}$ (see Figures $9 \mathrm{~b}$ and $9 \mathrm{~d}$ ). Nevertheless, also the resulting $\mathrm{N}_{2} \mathrm{O}$ consumption by $\mathrm{HB}$ was higher, which in turn compensated for the higher $\mathrm{N}_{2} \mathrm{O}$ production and smoothed considerably the resulting increase of the amount of $\mathrm{N}_{2} \mathrm{O}$ emitted. The cascade controller (CS3) was on the contrary able to optimize the oxygen supply better so that nitrite concentration was optimized also for cold temperatures.

\section{Robustness against sensor and actuator noise}

As can be noted by comparing the average $\mathrm{N}_{2} \mathrm{O}$ emitted per unit of influent TKN and unit of TKN removed with CS3 and CS4 according to each model, the novel control strategy $C S 3$, and presumably $C S 2$, can be considered robust against the sensor and actuator noise. CS4 is in fact able to achieve a drastic reduction of the $\mathrm{N}_{2} \mathrm{O}$ emissions compared to the open-loop. According to all the three models, the IAE and ISE values achieved using CS4 are slightly higher than the ones achieved with CS3, which in turn leads to slightly higher $\mathrm{N}_{2} \mathrm{O}$ emissions with CS4. Nonetheless, the manipulation of the oxygen mass transfer coefficient 
needed to cope with the imposed sensor and actuator noise seems to be much more aggressive, as can be noted from the calculated value of TV.

Table 5: $\mathrm{N}_{2} \mathrm{O}$ emission factors, average $\mathrm{R}_{\mathrm{NatAmm}}$ and average $\mathrm{N}_{2} \mathrm{O}$ produced by $\mathrm{HB}$ and AOB predicted by the BSM2Na, BSM2Nb and BSM2Nc with the four control strategies (CS1, CS2, CS3 and CS4).

Figure 9: (a) total $\mathrm{N}_{2} \mathrm{O}$ emitted, (b) $\mathrm{N}_{2} \mathrm{O}$ production by AOB in the aerobic zone, (c) average $\mathrm{NO}_{2}^{-}$ concentration in the aerobic zone, (d) $\mathrm{N}_{2} \mathrm{O}$ produced by $\mathrm{HB}$ in the aerobic zone (third HB denitrification step), (e) $\mathrm{N}_{2} \mathrm{O}$ consumed by $\mathrm{HB}$ in the aerobic zone (forth $\mathrm{HB}$ denitrification step), and (f) net $\mathrm{N}_{2} \mathrm{O}$ produced by HB in the aerobic zone (third plus forth denitrification steps), predicted by the BSM2Nc with CS1 (blue line), CS2 (green line) and CS3 (red line).

\subsection{Control performance on the effluent quality}

Within the context of mitigation of $\mathrm{N}_{2} \mathrm{O}$ emissions, the effluent quality has to be considered as well. Table 6 show the average TKN removal efficiency, $\mathrm{TN}$ removal efficiency, ammonium and total nitrogen violations and effluent quality index with $C S 1, C S 2, C S 3$ and $C S 4$ according to the BSM2Na, BSM2Nb and BSM2Nc predictions, respectively.

As can be noted, according to all the three models, CS2 and CS3 are able to keep the overall TKN removal efficiency at high levels. Furthermore, it can be easily demonstrated that the controllers are able to keep the frequency of ammonium effluent limit violations low $4 \mathrm{mg} \mathrm{N} . \mathrm{L}^{-1}$ ). CS3 performed considerably better in reducing the ammonium violations than $C S 2$.

The effluent ammonium violations obtained by $C S 1$ are negligible. The cascade PI controller is able to keep respecting the effluent ammonium limits throughout the entire simulation period and performs in this regard better than CS2 and CS3. The reason for this can be due to the fact that CS2 and CS3 have also to cope with $\mathrm{N}_{2} \mathrm{O}$ emissions, and the control objectives can be sometimes conflicting. In hot seasons aeration has to be increased to work out the lower NOB activity rate compared to AOB activity rate. Contrarily, in winter the controller, while keeping the nitrification complete, attempts to avoid aeration energy waste and high $\mathrm{N}_{2} \mathrm{O}$ production by HB denitrifiers. Thus there will be instances in cold temperatures when CS2 and CS3 will 
infer a decrease of the oxygen supply. As a consequence, this will cause a temporary increase of effluent ammonium, which can become higher than the effluent limit. Anyhow, CS2 and especially CS3 are able to ensure high TKN conversion, which means that they are able to cope with the slightly higher frequency of ammonium violations. To be noted is also that the TKN removal efficiency is higher when using CS3 than when using $C S 1$. As a drawback of $C S 2$ and $C S 3$, the effluent TN violations are variably increased. This has to be attributed to the higher COD demand by heterotrophic denitrifiers to perform the complete reduction of autotrophically-produced nitrogen oxides (such as nitrates and nitrites) into dinitrogen gas $\left(\mathrm{N}_{2}\right)$. As a matter of fact, since the controllers achieve a more complete oxidation of ammonium into nitrate and thus avoid nitrite leftover, HB denitrification will receive a higher load of nitrate in the anoxic zone, which requires more biodegradable COD for complete reduction to $\mathrm{N}_{2}$ (Hellinga et al., 1999). Consequently, due to incomplete denitrification, more nitrate will be in the effluent and a more severe violation of the effluent TN limit will occur, as shown in Table 6. For the same reason, the EQI significantly increases. Since CS3 was more able to achieve complete nitrification than $C S 2$, the EQI is worse when $C S 3$ is used.

Table 6: TKN and TN removal efficiencies, effluent average nitrate, ammonium and TN violations and effluent quality index predicted by the BSM2Na, BSM2Nb and BSM2Nc with the four control strategies (CS1, CS2, CS3 and CS4).

\subsection{Control performance on aeration energy consumptions}

To evaluate the economic feasibility of the control strategies, the aeration energy consumption (AEC) is considered (Table 7). As can be noted, CS2 and CS3 have led to a variable increment of the average aeration energy consumed according to all the three models. This was expected since more oxygen was needed in these strategies to ensure higher NOB activity. However, the variation is only between 3 and $6 \%$. More in detail, given the better regulation of the oxygen supply, some aeration energy could be saved by using the cascade configuration (CS3) rather than the regulatory controller (CS2). The energy consumption linked to the electricity consumption needed for the aeration system (surface aerators versus blowers) is another important component of the total carbon footprint of WWTPs. This contribution is proportional to a certain emission factor associated with type/source of electricity production (e.g. coal versus natural gas fired 
combustion versus renewable energy from wind, solar, etc...) and with the efficiency of aeration systems themselves. Since the quantification of the total carbon footprint is outside the scope of this contribution, average aeration energy consumption is instead used as an indicator to compare qualitatively the expected contribution by the aeration systems. Since the aeration energy consumption was only slightly affected by the novel control strategies tested in this study, it is expected that the proposed control strategy will lead to significant decrease in the total carbon footprint of the plant thanks to the major reduction on $\mathrm{N}_{2} \mathrm{O}$ emissions achieved by the controllers.

Table 7: Average aeration energy consumption $\left(\mathrm{kWh} \cdot \mathrm{d}^{-1}\right)$ with the four control strategies $(C S 1, C S 2, C S 3$ and CS4) according to the BSM2Na, BSM2Nb and BSM2Nc.

\subsection{Sensitivity of the controller against model parameters}

Table 8 compares the results achieved by simulating the BSM2Na using different $\mathrm{K}_{\mathrm{O} 2, \mathrm{AOB}}-\mathrm{K}_{\mathrm{O} 2 \text {,NOB }}$ couples taken from literature with the cascade control configuration for low $\mathrm{N}_{2} \mathrm{O}$ emissions (CS3) against the results achieved with the $\mathrm{NH}_{4}{ }^{+}$cascade controller (CS1). Two main situations can be identified from the results: (a) $\mathrm{K}_{\mathrm{O} 2, \mathrm{AOB}}$ is lower than $\mathrm{K}_{\mathrm{O} 2, \mathrm{NOB}}$, and (b) $\mathrm{K}_{\mathrm{O} 2, \mathrm{AOB}}$ is larger than $\mathrm{K}_{\mathrm{O} 2, \mathrm{NOB}}$. In the first case, the default controller CS1 is not able to keep the activities between NOB and AOB balanced. As a matter of fact, the average values achieved for $\mathrm{R}_{\mathrm{NatAmm}}$ are rather low. Contrarily, when CS3 is implemented, the average value for $\mathrm{R}_{\text {NatAmm }}$ is higher. The $\mathrm{N}_{2} \mathrm{O}$ emission factors achieved using CS3 are therefore much lower than the ones achieved using CSI. This improvement becomes larger as the difference between $\mathrm{K}_{\mathrm{O} 2, \mathrm{NOB}}$ and $\mathrm{K}_{\mathrm{O} \text {, АОВ }}$ increases. This is because NOB actvity is more limited by low oxygen concentrations than AOB activity.

On the other hand, when $\mathrm{K}_{\mathrm{O} 2, \mathrm{NOB}}$ is lower than $\mathrm{K}_{\mathrm{O} 2, \mathrm{AOB}}$, the values of $\mathrm{R}_{\mathrm{NatAmm}}$ achieved with $\mathrm{CS} 1$ are already in the ideal range necessary to minimize $\mathrm{N}_{2} \mathrm{O}$ emissions. This is due to the fact that, differently from the previous scenario, NOB are less limited by poor oxygen conditions than AOB. This means that for the same oxygen concentration, the aerobic activity rate of AOB will be lower than the one of NOB and no nitrification intermediates will accumulate. When CS3 is implemented instead, the supply of oygen tends to be higher, the residence time of $\mathrm{N}_{2} \mathrm{O}$ in the liquid phase is reduced and thus the rate of the last $\mathrm{HB}$ denitrification step gets reduced. Overall, the $\mathrm{N}_{2} \mathrm{O}$ emissions are slightly higher. These results suggest 
therefore that the novel control strategy proposed would be effective in drastically reducing $\mathrm{N}_{2} \mathrm{O}$ emssions only for those plants that have a considerable contribution from AOB denitrification.

Table 8: $\mathrm{N}_{2} \mathrm{O}$ emission actors, average $\mathrm{R}_{\mathrm{NatAmm}}$, and average aeration energy consumptions for the BSM2Na with different $\mathrm{K}_{\mathrm{O} 2, \mathrm{AOB}}-\mathrm{K}_{\mathrm{O} 2, \mathrm{NOB}}$ combinations. The last column is the literature reference where the parameter values were reported.

\section{Conclusions and future perspectives}

The work presented the development and testing of a novel control idea minimizing $\mathrm{N}_{2} \mathrm{O}$ emissions while at the same time keeping low ammonium concentrations in full-scale continuously-aerated WWTPs. The strategy is based on the concept that accumulation of nitrification intermediates like nitrite has to be avoided in order to prevent $\mathrm{N}_{2} \mathrm{O}$ production, and its consequent emission. In continuously aerated WWT systems, this can be done by triggering the ratio between $\mathrm{NOB}$ and $\mathrm{AOB}$ activity rates, which leads to minimization of nitrites produced by ammonia-oxidizing bacteria in aerobic environments.

The testing of the control strategy performed in this work was comprehensive. More specifically, the novel automated control strategy was found to enable achieving a drastic reduction of the total $\mathrm{N}_{2} \mathrm{O}$ emissions in those plants having $\mathrm{AOB}$ denitrification as main $\mathrm{N}_{2} \mathrm{O}$ producer. In plants where the incomplete $\mathrm{NH}_{2} \mathrm{OH}$ oxidation pathway was the main $\mathrm{N}_{2} \mathrm{O}$ producer, the controller was not as effective and a separate study should be performed to develop a control strategy specifically aimed at slowing down effectively this process.

The proposed control strategy is the first control technology being developed for automatic regulation of WWTP environmental conditions in function of online measurements with the specific aim of $\mathrm{N}_{2} \mathrm{O}$ emission mitigation.

The preliminary results presented in this work should be followed up by the implementation of the control strategy in full-scale WWTPs with the aim of drastically reducing their carbon footprint. However, there is a side effect of the controller which may lead to increase in the effluent total nitrogen and especially the nitrate concentrations. Therefore appropriate analysis and corresponding adaptations to plant operations - such as enhancing complete heterotrophic denitrification - are needed. 
629 630 631 632 633

\section{Acknowledgements}

The work has been funded in part by the Innovation Fund Denmark (IFD) (Project LaGAS, File No. 060300523B), and Veolia Water Technologies (Krüger, AnoxKaldnes, The Veolia Group). Support from the wastewater utilities (Biofos, DK; VA SYD, SE; Lyngby-Taarbæk forsyning, DK; FORS A/S, DK; Växjö, SE) and Unisense Environment, DK, and Fluxsense AB, SE is acknowledged.

Lisa Mears is acknowledged for English proof reading. Dr. Ulf Jeppsson is acknowledge for having provided the codes for the default BSM2.

\section{References}

Aboobakar, A., Cartmell, E., Stephenson, T., Jones, M., Vale, P., Dotro, G., 2013. Nitrous oxide emissions and dissolved oxygen profiling in a full-scale nitrifying activated sludge treatment plant. Water Res. 47, 524-534. doi:10.1016/j.watres.2012.10.004

Ahn, J.H., Kim, S., Park, H., Rahm, B., Pagilla, K., Chandran, K., 2010. N2O emissions from activated sludge processes, 2008-2009: results of a national monitoring survey in the United States. Environ. Sci. Technol. 44, 4505-4511. doi:10.1021/es903845y

Alex, J., Benedetti, L., Copp, J., Gernaey, K. V, 2008. Benchmark Simulation Model no . 1 ( BSM1 ) Contributors 1.

Behera, C.R., Srinivasan, B., Chandran, K., Venkatasubramanian, V., 2015. Model based predictive control for energy efficient biological nitrification process with minimal nitrous oxide production. Chem. Eng. J. 268, 300-310. doi:10.1016/j.cej.2015.01.044

Blackburne, R., Yuan, Z., Keller, J., 2008. Partial nitrification to nitrite using low dissolved oxygen concentration as the main selection factor. Biodegradation 19, 303-312. 
Boiocchi, R., 2016. Plant-wide modelling and control of N2O emissions from wastewater treatment plants.

654

655

656

657

658

659

660

661

662

663

664

665

666

667

668

669

670

671

672

673

674

675

676

Boiocchi, R., Gernaey, K. V., Sin, G., 2017. Understanding N2O formation mechanisms through sensitivity analyses using a plant-wide benchmark simulation model. Chem. Eng. J. 317, 935-951. doi:10.1016/j.cej.2017.02.091

Boiocchi, R., Gernaey, K. V, Sin, G., 2016. Systematic design of membership functions for fuzzy-logic control: A case study on one-stage partial nitritation/anammox treatment systems. Water Res. 102, 346-361. doi:10.1016/j.watres.2016.06.047

Boiocchi, R., Gernaey, K. V, Sin, G., 2015. Extending the benchmark simulation model no2 with processes for nitrous oxide production and side-stream nitrogen removal, in: 12th International Symposium on Process Systems Engineering and 25th European Symposium on Computer Aided Process Engineering. Elsevier, pp. 2477-2482. doi:10.1016/B978-0-444-63576-1.50107-2

Cosenza, A., Mannina, G., Vanrolleghem, P.A., Neumann, M.B., 2014. Variance-based sensitivity analysis for wastewater treatment plant modelling. Sci. Total Environ. 470-471, 1068-1077. doi:10.1016/j.scitotenv.2013.10.069

Daelman, M.R.J., van Voorthuizen, E.M., van Dongen, U.G.J.M., Volcke, E.I.P., van Loosdrecht, M.C.M., 2015. Seasonal and diurnal variability of $\mathrm{N} 2 \mathrm{O}$ emissions from a full-scale municipal wastewater treatment plant. Sci. Total Environ. 536, 1-11. doi:10.1016/j.scitotenv.2015.06.122

Domingo-Felez, C., Smets, B.F., 2016. A consilience model to describe N2O production during biological N removal. Environ. Sci. water Res. Technol. 2, 923-930.

Fischedick, M., Roy, J., Abdel-Aziz, A., Acquaye, A., Allwood, J.M., Ceron, J.-P., Geng, Y., Kheshgi, H., Lanza, A., Perczyk, D., Price, L., Santalla, E., Sheinbaum, C., Tanaka, K., 2014. Industry. In: Climate Change 2014: Mitigation of Climate Change. Contribution of Working Group III to the Fifth Assessment Report of the Intergovernmental Panel on Climate Change [Edenhofer, O., R. PichsMadruga, Y. Sokona, E. Farahani, S. Kadner, K. Seyb.

Foley, J., de Haas, D., Yuan, Z., Lant, P., 2010. Nitrous oxide generation in full-scale biological nutrient 
Guisasola, A., Jubany, I., Baeza, J.A., Carrera, J., Lafuente, J., 2005. Respirometric estimation of the oxygen affinity constants for biological ammonium and nitrite oxidation. J. Chem. Technol. Biotechnol. 80, 388-396.

Guo, L., Vanrolleghem, P.A., 2014. Calibration and validation of an activated sludge model for greenhouse gases no. 1 (ASMG1): prediction of temperature-dependent $\mathrm{N} 2 \mathrm{O}$ emission dynamics. Bioprocess Biosyst. Eng. 37, 151-163. doi:10.1007/s00449-013-0978-3

Hellinga, C., van Loosdrecht, M.C.M., Heijnen, J.J., 1999. Model Based Design of a Novel Process for Nitrogen Removal from Concentrated Flows. Math. Comput. Model. Dyn. Syst. 5, 351-371.

Hiatt, W.C., Grady, C.P.L., 2008. An updated process model for carbon oxidation, nitrification, and denitrification. Water Environ. Res. 80, 2145-56.

Holenda, B., Domokos, E., Fazakas, J., 2008. Dissolved oxygen control of the activated sludge wastewater treatment process using model predictive control. Comput. Chem. Eng. 32, 1270-1278. doi:10.1016/j.compchemeng.2007.06.008

Jeppsson, U., Pons, M.-N., Nopens, I., Alex, J., Copp, J.B., Gernaey, K. V, Rosen, C., Steyer, J.-P., Vanrolleghem, P. a, 2007. Benchmark simulation model no 2: general protocol and exploratory case studies. Water Sci. Technol. 56, 67-78. doi:10.2166/wst.2007.604

Laudelout, H., Lambert, R., Fripiat, J.L., Pham, M.L., 1974. Effect of temperature in the velocity of oxidation of ammonia to nitrate in mixed nitrifier culture. Ann. Microbiol. 125B, 75-84.

Manser, R., Gujer, W., Siegrist, H., 2005. Consequences of mass transfer effects on the kinetics of nitrifiers. Water Res. 39, 4633-4642. doi:10.1016/j.watres.2005.09.020

Ni, B.-J., Ye, L., Law, Y., Byers, C., Yuan, Z., 2013. Mathematical modeling of nitrous oxide (N2O) emissions from full-scale wastewater treatment plants. Environ. Sci. Technol. 47, 7795-7803.

Peeters, T.L., Van Goal, A.D., Landelout, H., 1969. Kinetic study of oxygen limited respiration in nitrifying 
bacteria. Bact. Proc. 58, 141.

Peng, L., Ni, B.-J., Erler, D., Ye, L., Yuan, Z., 2015. The combined effect of dissolved oxygen and nitrite on N2O production by ammonia oxidizing bacteria in an enriched nitrifying sludge. Water Res. 73, 29-36. doi:10.1016/j.watres.2014.08.009

Peng, L., Ni, B.-J., Erler, D., Ye, L., Yuan, Z., 2014. The effect of dissolved oxygen on N2O production by ammonia-oxidizing bacteria in an enriched nitrifying sludge. Water Res. 66, 12-21. doi:10.1016/j.watres.2014.08.009

Picioreanu, C., Pérez, J., van Loosdrecht, M.C.M., 2016. Impact of cell cluster size on apparent halfsaturation coefficients for oxygen in nitrifying sludge and biofilms. Water Res. 106, 371-382. doi:10.1016/j.watres.2016.10.017

Pocquet, M., Wu, Z., Queinnec, I., Spérandio, M., 2016. A two pathway model for N2O emissions by ammonium oxidizing bacteria supported by the NO/N2O variation. Water Res. 88, 948-959. doi:10.1016/j.watres.2015.11.029

Sin, G., De Pauw, D.J.W., Weijers, S., Vanrolleghem, P.A., 2008. An efficient approach to automate the manual trial and error calibration of activated sludge models. Biotechnol. Bioeng. 100, 516-528. doi:10.1002/bit.21769

Sin, G., Gernaey, K. V., Neumann, M.B., van Loosdrecht, M.C.M., Gujer, W., 2009. Uncertainty analysis in WWTP model applications: A critical discussion using an example from design. Water Res. 43, 28942906. doi:10.1016/j.watres.2009.03.048

Spérandio, M., Pocquet, M., Guo, L., Ni, B.-J., Vanrolleghem, P.A., Yuan, Z., 2016. Evaluation of different nitrous oxide production models with four continuous long-term wastewater treatment process data series. Bioprocess Biosyst. Eng. 39, 493-510. doi:10.1007/s00449-015-1532-2

Stenström, F., Tjus, K., Jansen, J. la C., 2014. Oxygen-induced dynamics of nitrous oxide in water and offgas during the treatment of digester supernatant. Water Sci. Technol. 69, 84-91. doi:10.2166/wst.2013.558 
727 Sun, S., Bao, Z., Sun, D., 2014. Study on emission characteristics and reduction strategy of nitrous oxide during wastewater treatment by different processes. Environ. Sci. Pollut. Res. 22, 4222-4229. doi:10.1007/s11356-014-3654-5

Tallec, G., Garnier, J., Billen, G., Gousailles, M., 2008. Nitrous oxide emissions from denitrifying activated sludge of urban wastewater treatment plants, under anoxia and low oxygenation. Bioresour. Technol.

Tallec, G., Garnier, J., Billen, G., Gousailles, M., 2006. Nitrous oxide emissions from secondary activated sludge in nitrifying conditions of urban wastewater treatment plants: Effect of oxygenation level. Water 99, 2200-2209. doi:10.1016/j.biortech.2007.05.025 Res. 40, 2972-2980. doi:10.1016/j.watres.2006.05.037 


\section{APPENDIX A1 \\ Expected effect of controllers on HB denitrification}

Since ensuring complete nitrification means that all the $\mathrm{NO}_{2}{ }^{-}$produced by $\mathrm{AOB}$ is consumed by NOB, this control strategy is expected to slow down not only the $\mathrm{N}_{2} \mathrm{O}$ production by AOB denitrifiers but also the gross $\mathrm{N}_{2} \mathrm{O}$ production by $\mathrm{HB}$ in the aerobic zone. As a matter of fact, it can occur due to low presence of oxygen and nitrite build-up that $\mathrm{HB}$ will start using AOB-produced nitrites as electron acceptors for the oxidation of organic carbon and thus produce $\mathrm{N}_{2} \mathrm{O}$, which, contrarily to what would happen in an anoxic zone, is likely to strip fast to the atmosphere given the higher stripping capability of the aerobic zone. This is because typical aeration regimes in the aerobic zone are established with the aim of guaranteeing effluent total ammonia concentrations below legal limits. However, also the last $\mathrm{HB}$ denitrification step, consuming $\mathrm{N}_{2} \mathrm{O}$, is slowed down by increased oxygen concentrations. The effect of oxygen on the $\mathrm{N}_{2} \mathrm{O}$ net produced by $\mathrm{HB}$ and on the total $\mathrm{N}_{2} \mathrm{O}$ emissions needs therefore to be properly verified through control testing.

\section{Reasons for not choosing $\mathrm{N}_{2} \mathrm{O}$ and $\mathrm{NO}_{2}^{-}$as controlled variables}

On-line measurements of $\mathrm{N}_{2} \mathrm{O}$ concentrations in the liquid phase in the aeration zone are not considered useful for the achievement of the control objectives. As a matter of fact, the $\mathrm{N}_{2} \mathrm{O}$ concentrations in the liquid phase can be rather low in an aerated zone, given the high stripping capability. These very low concentrations are much more subject to measurement errors, which in turn would hinder the good performance of a controller using $\mathrm{N}_{2} \mathrm{O}$ measurements as an input. Furthermore, mere $\mathrm{N}_{2} \mathrm{O}$ measurements do not help the controller to decide whether an increase or a decrease in the control action has to be inferred. On the contrary, measurements of nitrites in the aerobic zone would help detect an incomplete nitrification and, hence, influence the decision on the proper control action to be taken. However, not the entire $\mathrm{N}_{2} \mathrm{O}$ is produced as a consequence of nitrite accumulation. There is in fact a high production of $\mathrm{N}_{2} \mathrm{O}$ due to establishment of a critical concentration of dissolved oxygen (DO) which promotes $\mathrm{NH}_{2} \mathrm{OH}$ build-up while the $\mathrm{NO}_{2}{ }^{-}$pick up by AOB is not inhibited yet. Since the nitrite measured would be able to quantify only the nitrite left over from all the reactions consuming it, in this specific case quite low nitrite concentrations can 
result while a rather high $\mathrm{N}_{2} \mathrm{O}$ production occurs. Nitrite measurements are therefore considered not representative of the entire $\mathrm{N}_{2} \mathrm{O}$ production.

\section{APPENDIX A2 - The optimal value for $\mathbf{R}_{\text {NatAmm }}$}

The difference between ammonium concentrations at the inlet and the outlet of the aerobic zone is supposed to quantify the amount of ammonium consumed by AOB whereas the difference between nitrate in the outlet and in the inlet of the aerobic zone quantifies the amount of nitrate produced by NOB. It is important that the measurements are taken from the inlet and the outlet of an aerobic zone and not of an entire WWTP. This is because the difference between nitrate in the plant effluent and in the plant influent would not represent the $\mathrm{NOB}$ activity only, since $\mathrm{NO}_{3}{ }^{-}$consumption by heterotrophs would be involved as well as an interfering process. Given these considerations, the theoretical value of $\mathrm{R}_{\mathrm{NatAmm}}$ indicating complete nitrification should be around 1, which indicates that the ammonium consumed is equal to the amount of nitrate produced and no nitrification intermediate is used to produce $\mathrm{N}_{2} \mathrm{O}$. Nevertheless, the difference between ammonium in and out the aerobic zone does not entirely incorporate all the ammonium consumed by AOB. As a matter of fact, when most of the ammonium is depleted, AOB start using the influent organic nitrogen, which is quickly hydrolysed and ammonified, as electron donor. The nitrite produced thereby is subsequently converted into nitrate by NOB, which is added to the amount of nitrate produced from the oxidation of influent ammonium. The difference between nitrate in the outlet and the inlet to the aerobic zone will as a result be slightly higher than the difference between ammonium in the inlet and the outlet.

As far as the ammonium consumed as nutrient by the biomass, this quantity can be neglected for the following reasons: (a) the autotrophic biomass is only a small percentage of the overall sludge and therefore does not consume a relevant quantity of ammonium for growth; (b) part of the ammonium consumed as nutrient is subsequently released during biomass decay; (c) in a predenitrification configuration, heterotrophic biomass grows very slowly in the aerobic zone as most of the organic carbon is consumed in the anoxic compartment.

This explains why the optimal value of $\mathbf{R}_{\text {NatAmm }}$ resulting from Figure $3 b$ is higher than 1, i.e. 1.2. 


\section{APPENDIX A3}

\section{Model for mainstream activated sludge processes in the BSM2Na}

Table 1: (a) Stoichiometric matrix and (b) Kinetic vector for the AOB-mediated processes.

(a)

\begin{tabular}{|c|c|c|c|c|c|c|}
\hline \multicolumn{7}{|c|}{ Stoichiometric matrix } \\
\hline & $S_{N H X}$ & $\mathrm{~S}_{\mathrm{NO} 2}$ & $S_{O 2}$ & $S_{N O}$ & $S_{N 2 O}$ & $X_{A O B}$ \\
\hline $\begin{array}{c}\text { Aerobic } \\
\text { AOB } \\
\text { growth }\end{array}$ & $-1 / Y_{A O B}-i_{N X B}$ & $1 / Y_{A O B}$ & $-\left(3.43-Y_{A O B}\right) / Y_{A O B}$ & & & 1 \\
\hline $\begin{array}{c}\text { Anoxic } \\
\mathrm{AOB}^{-} \\
\text {growth on } \\
\mathrm{NO}_{2}^{-}\end{array}$ & $-1 / Y_{A O B^{-}} i_{N X B}$ & $-1 / Y_{A O B}$ & $-\left(2.29-Y_{A O B}\right) / Y_{A O B}$ & $2 / Y_{A O B}$ & & 1 \\
\hline $\begin{array}{c}\text { Anoxic } \\
\text { AOB } \\
\text { growth on } \\
\text { NO }\end{array}$ & $-1 / Y_{A O B}-i_{N X B}$ & $1 / Y_{A O B}$ & $-\left(2.29-Y_{A O B}\right) / Y_{A O B}$ & $-2 / Y_{A}$ & $2 / Y_{A O B}$ & 1 \\
\hline
\end{tabular}

(b)

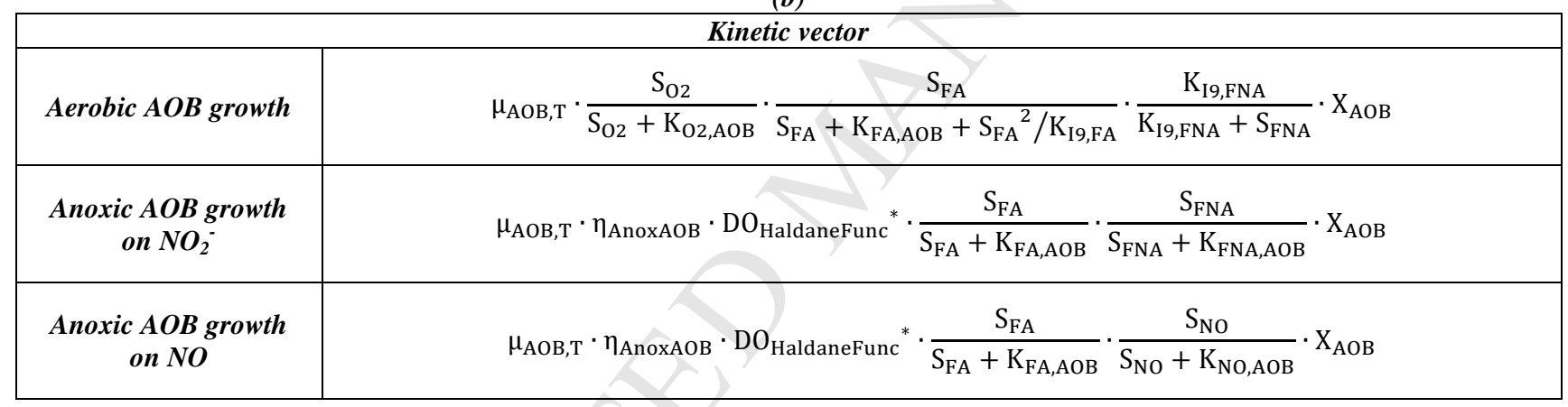

$$
\mathrm{DO}_{\text {HaldaneFunc }}{ }^{*}=\frac{\mathrm{S}_{\mathrm{O} 2}}{\mathrm{~K}_{\mathrm{SO} 2, \mathrm{AOBden}}+\left(1-2 \cdot \sqrt{\mathrm{K}_{\mathrm{SO} 2, \mathrm{AOBden}} / \mathrm{K}_{\mathrm{IO}, \mathrm{AOBden}}}\right) \cdot \mathrm{S}_{\mathrm{O} 2}+\mathrm{S}_{\mathrm{O} 2}{ }^{2} / \mathrm{K}_{\mathrm{IO}, \mathrm{AOBden}}}
$$

Table 2: (a) stoichiometric matrix and (b) kinetic vector for the NOB activity.

(a)

\begin{tabular}{|c|c|c|c|c|}
\hline \multicolumn{5}{|c|}{ Stoichiometric matrix } \\
\hline $\begin{array}{c}\text { Aerobic NOB } \\
\text { growth }\end{array}$ & $S_{N H X}$ & $S_{N O 2}$ & $S_{O 2}$ & $X_{N O B}$ \\
\hline
\end{tabular}

(b)

\begin{tabular}{|c|c|c|c|c|c|}
\hline \multicolumn{6}{|c|}{ Kinetic vector } \\
\hline \multirow{2}{*}{$\begin{array}{l}\text { Aerobic } N O B \\
\text { growth }\end{array}$} & \multirow[b]{2}{*}{$\mu_{\mathrm{NOB}, \mathrm{T}}$} & $\mathrm{S}_{\mathrm{FNA}}$ & $\mathrm{S}_{\mathrm{O} 2}$ & $\mathrm{~K}_{\mathrm{I} 10, \mathrm{FA}}$ & \multirow{2}{*}{$\cdot \mathrm{X}_{\mathrm{NOB}}$} \\
\hline & & $\mathrm{S}_{\mathrm{FNA}}+\mathrm{K}_{\mathrm{FNA}, \mathrm{NOB}}+\mathrm{S}_{\mathrm{FNA}}{ }^{2} / \mathrm{K}_{\mathrm{I} 10, \mathrm{FNA}}$ & $\overline{\mathrm{S}_{\mathrm{O} 2}+\mathrm{K}_{\mathrm{O} 2, \mathrm{NOB}}}$ & $\overline{\mathrm{K}_{\mathrm{I} 10, \mathrm{FA}}+\mathrm{S}_{\mathrm{FA}}}$ & \\
\hline
\end{tabular}


Table 3: (a) stoichiometric matrix and (b) kinetic vector for the HB-mediated processes.

(a)

\begin{tabular}{|c|c|c|c|c|c|c|c|c|}
\hline \multicolumn{9}{|c|}{ Stoichiometric matrix } \\
\hline & $S_{S}$ & $S_{O 2}$ & $S_{N O 3}$ & $S_{\mathrm{NO} 2}$ & $S_{N O}$ & $S_{N 2 O}$ & $S_{N 2}$ & $X_{H B}$ \\
\hline $\begin{array}{c}\text { Aerobic HB } \\
\text { growth }\end{array}$ & $-\frac{1}{Y_{H}}$ & $\frac{1-Y_{H}}{Y_{H}}$ & & & & & & 1 \\
\hline $\begin{array}{c}\text { Anoxic } \mathrm{HB} \\
\text { growth on } \mathrm{NO}_{3}^{-}\end{array}$ & $-\frac{1}{n_{Y} \cdot Y_{H}}$ & & $-A$ & A & & & & 1 \\
\hline $\begin{array}{c}\text { Anoxic } \mathrm{HB} \\
\text { growth on } \mathrm{NO}_{2}^{-}\end{array}$ & $-\frac{1}{n_{Y} \cdot Y_{H}}$ & & & $-B$ & $B$ & & & 1 \\
\hline $\begin{array}{c}\text { Anoxic } H B \\
\text { growth on } N O\end{array}$ & $-\frac{1}{n_{Y} \cdot Y_{H}}$ & & & & $-B$ & $B$ & & 1 \\
\hline $\begin{array}{c}\text { Anoxic } \mathrm{HB} \\
\text { growth on } \mathrm{N}_{2} \mathrm{O}\end{array}$ & $-\frac{1}{n_{Y} \cdot Y_{H}}$ & & & & & -1 & $B$ & 1 \\
\hline
\end{tabular}

$$
\begin{aligned}
& A=\frac{1-Y_{H} \cdot n_{Y}}{1.143 \cdot Y_{H} \cdot n_{Y}} \\
& B=\frac{1-Y_{H} \cdot n_{Y}}{0.571 \cdot Y_{H} \cdot n_{Y}}
\end{aligned}
$$

(b)

\begin{tabular}{|c|c|}
\hline \multicolumn{1}{|c|}{ Kerobic HB growth } & $\mu_{\mathrm{HB}, \mathrm{T}} \cdot \frac{\mathrm{S}_{\mathrm{S}}}{\mathrm{S}_{\mathrm{S}}+\mathrm{K}_{\mathrm{S} 1}} \cdot \frac{\mathrm{S}_{\mathrm{O} 2}}{\mathrm{~S}_{\mathrm{O} 2}+\mathrm{K}_{\mathrm{OH} 1}} \cdot \frac{\mathrm{S}_{\mathrm{NH}}}{\mathrm{S}_{\mathrm{NH}}+\mathrm{K}_{\mathrm{NH}, \mathrm{HB}}} \cdot \mathrm{X}_{\mathrm{HB}}$ \\
\hline $\begin{array}{c}\text { Anoxic HB growth on } \\
\boldsymbol{N O}_{3}^{-}\end{array}$ & $\mu_{\mathrm{HB}, \mathrm{T}} \cdot \eta_{\mathrm{AnoxHB}, 2} \cdot \frac{\mathrm{S}_{\mathrm{S}}}{\mathrm{S}_{\mathrm{S}}+\mathrm{K}_{\mathrm{S} 2}} \cdot \frac{\mathrm{K}_{\mathrm{OH} 2}}{\mathrm{~S}_{\mathrm{O} 2}+\mathrm{K}_{\mathrm{OH} 2}} \cdot \frac{\mathrm{S}_{\mathrm{NO} 3}}{\mathrm{~S}_{\mathrm{NO} 3}+\mathrm{K}_{\mathrm{NO} 3}} \cdot \mathrm{X}_{\mathrm{HB}}$ \\
\hline $\begin{array}{c}\text { Anoxic HB growth on } \\
\boldsymbol{N O}_{2}^{-}\end{array}$ & $\mu_{\mathrm{HB}, \mathrm{T}} \cdot \eta_{\mathrm{AnoxHB}, 3} \cdot \frac{\mathrm{S}_{\mathrm{S}}}{\mathrm{S}_{\mathrm{S}}+\mathrm{K}_{\mathrm{S} 3}} \cdot \frac{\mathrm{K}_{\mathrm{OH} 3}}{\mathrm{~S}_{\mathrm{O} 2}+\mathrm{K}_{\mathrm{OH} 3}} \cdot \frac{\mathrm{S}_{\mathrm{NO} 2}}{\mathrm{~S}_{\mathrm{NO} 2}+\mathrm{K}_{\mathrm{NO} 2}} \cdot \frac{\mathrm{K}_{\mathrm{I} 3, \mathrm{NO}}}{\mathrm{K}_{\mathrm{I}, \mathrm{NO}}+\mathrm{S}_{\mathrm{NO}}} \cdot \mathrm{X}_{\mathrm{HB}}$ \\
\hline $\begin{array}{c}\text { Anoxic HB growth on } \\
\text { Anoxic HB growth on } \\
\boldsymbol{N}_{2} \boldsymbol{O}\end{array}$ & $\mu_{\mathrm{HB}, \mathrm{T}} \cdot \eta_{\mathrm{AnoxHB}, 4} \cdot \frac{\mathrm{S}_{\mathrm{S}}}{\mathrm{S}_{\mathrm{S}}+\mathrm{K}_{\mathrm{S} 4}} \cdot \frac{\mathrm{K}_{\mathrm{OH} 4}}{\mathrm{~S}_{\mathrm{O} 2}+\mathrm{K}_{\mathrm{OH} 4}} \cdot \frac{\mathrm{S}_{\mathrm{NO}}}{\mathrm{S}_{\mathrm{NO}}+\mathrm{K}_{\mathrm{NO}}+\mathrm{S}_{\mathrm{NO}}{ }^{2} / \mathrm{K}_{\mathrm{I} 4 \mathrm{NO}}} \cdot \mathrm{X}_{\mathrm{HB}}$ \\
\hline$\mu_{\mathrm{HB}, \mathrm{T}} \cdot \eta_{\mathrm{AnoxHB}, 5} \cdot \frac{\mathrm{S}_{\mathrm{S}}}{\mathrm{S}_{\mathrm{S}}+\mathrm{K}_{\mathrm{S} 5}} \cdot \frac{\mathrm{K}_{\mathrm{OH} 5}}{\mathrm{~S}_{\mathrm{O} 2}+\mathrm{K}_{\mathrm{OH} 5}} \cdot \frac{\mathrm{S}_{\mathrm{N} 2 \mathrm{O}}}{\mathrm{S}_{\mathrm{N} 2 \mathrm{O}}+\mathrm{K}_{\mathrm{N} 2 \mathrm{O}}} \cdot \frac{\mathrm{K}_{\mathrm{I}, \mathrm{NO}}}{\mathrm{K}_{\mathrm{I}, \mathrm{NO}}+\mathrm{S}_{\mathrm{NO}}} \cdot \mathrm{X}_{\mathrm{HB}}$ \\
\hline
\end{tabular}

\begin{tabular}{|c|c|c|c|}
\hline Parameters & Description & Default value at $15^{\circ} \mathrm{C}$ & Unit \\
\hline \multicolumn{4}{|c|}{ Aerobic AOB activity } \\
\hline $\mathbf{Y}_{\mathrm{AOB}}$ & growth yield of $\mathrm{AOB}$ & 0.18 & $\mathrm{~g} \mathrm{COD}_{\text {BIO }} \cdot \mathrm{g}^{-1} \mathrm{~N}$ \\
\hline$\mu_{\mathrm{AOB}}$ & maximum specific growth rate of $\mathrm{AOB}$ & 0.58 & $\mathrm{~d}^{-1}$ \\
\hline $\mathbf{K}_{\mathrm{FA}}$ & $\mathrm{NH}_{3}$ half saturation parameter for aerobic AOB activity & 0.004 & g N.m ${ }^{-3}$ \\
\hline $\mathbf{K}_{\mathbf{O}, \mathrm{AOB}}$ & $\mathrm{O}_{2}$ half-saturation constant for AOB activity & 0.6 & $\mathrm{~g}(-\mathrm{COD}) \cdot \mathrm{m}^{-3}$ \\
\hline $\mathrm{K}_{\mathbf{I 9 , F A}}$ & $\mathrm{NH}_{3}$ inhibition constant for AOB activity & 1 & g N.m ${ }^{-3}$ \\
\hline $\mathrm{K}_{\mathrm{I}, \mathrm{FNA}}$ & $\mathrm{HNO}_{2}$ inhibition constant for AOB activity & 0.1 & g N.m ${ }^{-3}$ \\
\hline
\end{tabular}

Table 4: Parameter values used in the BSM2Na for the biological processes. 


\begin{tabular}{|c|c|c|c|}
\hline $\mathbf{b}_{\mathrm{A} 1}$ & decay coefficient of AOB & 0.028 & $\mathrm{~d}^{-1}$ \\
\hline \multicolumn{4}{|c|}{ NOB activity } \\
\hline$\overline{Y_{\text {NOB }}}$ & growth yield of NOB & 0.06 & $\mathrm{~g} \mathrm{COD}_{\text {ВІо }} \cdot \mathrm{g}^{-1} \mathrm{~N}$ \\
\hline$\mu_{\mathrm{NOB}}$ & maximum specific growth rate of NOB & 0.68 & $\mathrm{~d}^{-1}$ \\
\hline $\mathbf{K}_{\mathbf{O}, \mathrm{NOB}}$ & $\mathrm{O}_{2}$ half-saturation constant for NOB activity & 1.2 & $\mathrm{~g}(-\mathrm{COD}) \cdot \mathrm{m}^{-3}$ \\
\hline $\mathbf{K}_{\mathrm{I10,FA}}$ & $\mathrm{NH}_{3}$ inhibition constant for NOB activity & 0.5 & g N.m ${ }^{-3}$ \\
\hline $\mathbf{K}_{\mathrm{II0,FNA}}$ & $\mathrm{HNO}_{2}$ inhibition constant for NOB activity & 0.1 & g N.m ${ }^{-3}$ \\
\hline $\mathbf{K}_{\mathrm{FNA}}$ & $\mathrm{HNO}_{2}$ half saturation parameter for NOB activity & $10-6$ & g N.m ${ }^{-3}$ \\
\hline $\mathbf{b}_{\mathrm{A} 2}$ & decay coefficient of NOB & 0.028 & $\mathrm{~d}^{-1}$ \\
\hline \multicolumn{4}{|c|}{ Aerobic HB activity } \\
\hline $\mathbf{Y}_{\mathrm{H}}$ & growth yield of $\mathrm{HB}$ & 0.6 & $\mathrm{~g} \mathrm{COD}_{\text {BIO }} \mathrm{g}^{-1} \mathrm{COD}$ \\
\hline$\mu_{\mathrm{H}}$ & maximum specific growth rate of $\mathrm{HB}$ & 4.78 & $\mathrm{~d}^{-1}$ \\
\hline $\mathbf{K}_{\mathrm{S} 1}$ & $\mathrm{~S}_{\mathrm{s}}$ half-saturation coefficient for aerobic HB activity & 15 & g COD. $\mathrm{m}^{-3}$ \\
\hline $\mathbf{K}_{\mathrm{OH} 1}$ & $\mathrm{O}_{2}$ half saturation coefficient for aerobic HB activity & 0.2 & $\mathrm{~g}(-\mathrm{COD}) \cdot \mathrm{m}^{-3}$ \\
\hline $\mathbf{b}_{\mathrm{H}}$ & decay coefficient of HB & 0.3 & $\mathrm{~d}^{-1}$ \\
\hline \multicolumn{4}{|c|}{ HB denitrification } \\
\hline$\overline{\mathbf{n}_{\mathbf{Y}}}$ & anoxic reduction factor for $\mathrm{HB}$ yield & 0.9 & {$[-]$} \\
\hline $\mathbf{K}_{\mathrm{I3,NO}}$ & NO inhibition constant of for $\mathrm{HB}$-mediated $\mathrm{NO}_{2}$ - reduction & 0.5 & g N.m ${ }^{-3}$ \\
\hline $\mathbf{K}_{\mathrm{I}, \mathrm{NO}}$ & NO inhibition constant of for HB-mediated NO reduction & 0.3 & g N.m ${ }^{-3}$ \\
\hline $\mathbf{K}_{\mathrm{I}, \mathrm{NO}}$ & $\mathrm{NO}$ inhibition constant of for $\mathrm{HB}$-mediated $\mathrm{N}_{2} \mathrm{O}$ reduction & 0.2 & g N.m $m^{-3}$ \\
\hline $\mathbf{K}_{\mathrm{N} 2 \mathrm{O}}$ & $\mathrm{N}_{2} \mathrm{O}$ half-saturation for $\mathrm{HB}$-mediated $\mathrm{N}_{2} \mathrm{O}$ reduction & 0.02 & g N.m ${ }^{-3}$ \\
\hline $\mathbf{K}_{\mathrm{NO}}$ & NO half-saturation for HB-mediated NO reduction & 0.04 & g N.m ${ }^{-3}$ \\
\hline $\mathbf{K}_{\mathrm{NO} 2}$ & $\mathrm{NO}_{2}$ - half-saturation for $\mathrm{HB}$-mediated $\mathrm{NO}_{2}$ - reduction & 0.3 & g N.m ${ }^{-3}$ \\
\hline $\mathbf{K}_{\mathrm{NO3}}$ & $\mathrm{NO}_{3}$ - half-saturation for $\mathrm{HB}$-mediated $\mathrm{NO}_{3}$ - reduction & 1.5 & g N.m ${ }^{-3}$ \\
\hline $\mathbf{K}_{\mathbf{S} 2}$ & $\mathrm{~S}_{\mathrm{s}}$ inhibition coefficient for $\mathrm{HB}$-mediated $\mathrm{NO}_{3}$ - reduction & 20 & g COD. $\mathrm{m}^{-3}$ \\
\hline $\mathbf{K}_{\mathbf{S 3}}$ & $\mathrm{S}_{\mathrm{S}}$ inhibition coefficient for $\mathrm{HB}$-mediated $\mathrm{NO}_{3}$ - reduction & 20 & g COD. $\mathrm{m}^{-3}$ \\
\hline $\mathbf{K}_{\mathrm{S} 4}$ & $\mathrm{~S}_{\mathrm{S}}$ inhibition coefficient for $\mathrm{HB}-$ mediated NO reduction & 20 & g COD. $\mathrm{m}^{-3}$ \\
\hline $\mathbf{n}_{\mathrm{g} 2}$ & reduction factor for $\mathrm{HB}$ anoxic growth on $\mathrm{NO}_{3^{-}}$ & 0.3 & {$[-]$} \\
\hline $\mathbf{n}_{\mathrm{g} 3}$ & reduction factor for $\mathrm{HB}$ anoxic growth on $\mathrm{NO}_{2^{-}}$ & 0.3 & {$[-]$} \\
\hline $\mathbf{n}_{\mathrm{g} 4}$ & reduction factor for $\mathrm{HB}$ anoxic growth on $\mathrm{NO}$ & 0.6 & {$[-]$} \\
\hline $\mathbf{n}_{\mathrm{g} 5}$ & reduction factor for $\mathrm{HB}$ anoxic growth on $\mathrm{N}_{2} \mathrm{O}$ & 0.8 & {$[-]$} \\
\hline $\mathbf{K}_{\mathbf{S 5}}$ & $\mathrm{S}_{\mathrm{S}}$ inhibition coefficient for $\mathrm{HB}$-mediated $\mathrm{N}_{2} \mathrm{O}$ reduction & 30 & g COD.m. ${ }^{-3}$ \\
\hline $\mathrm{K}_{\mathrm{OH} 2}$ & $\mathrm{O}_{2}$ inhibition coefficient for $\mathrm{HB}$-mediated $\mathrm{NO}_{3}$ - reduction & 0.2 & $\mathrm{~g}(-\mathrm{COD}) \cdot \mathrm{m}^{-3}$ \\
\hline $\mathbf{K}_{\mathrm{OH} 3}$ & $\mathrm{O}_{2}$ inhibition coefficient for $\mathrm{HB}$-mediated $\mathrm{NO}_{2}$ - reduction & 0.2 & $\mathrm{~g}(-\mathrm{COD}) \cdot \mathrm{m}^{-3}$ \\
\hline $\mathrm{K}_{\mathrm{OH} 4}$ & $\mathrm{O}_{2}$ inhibition coefficient for $\mathrm{HB}$-mediated $\mathrm{NO}$ reduction & 0.2 & $\mathrm{~g}(-\mathrm{COD}) \cdot \mathrm{m}^{-3}$ \\
\hline $\mathbf{K}_{\mathrm{OH} 5}$ & $\mathrm{O}_{2}$ inhibition coefficient for $\mathrm{HB}$-mediated $\mathrm{N}_{2} \mathrm{O}$ reduction & 0.2 & $\mathrm{~g}(-\mathrm{COD}) \cdot \mathrm{m}^{-3}$ \\
\hline \multicolumn{4}{|c|}{ Hydrolysis of particulate organics } \\
\hline $\mathbf{k}_{\mathbf{h}}$ & maximum specific hydrolysis rate & 2.89 & $\mathrm{~g} \mathrm{COD.g}^{-1} \mathrm{COD}_{\text {BIO }}$ \\
\hline $\mathbf{n}_{\mathrm{h}}$ & reduction factor for hydrolysis & 0.8 & {$[-]$} \\
\hline $\mathbf{K}_{\mathrm{OH}}$ & $\mathrm{O}_{2}$ half-saturation coefficient for hydrolysis & 0.2 & $\mathrm{~g}(-\mathrm{COD}) \cdot \mathrm{m}^{-3}$ \\
\hline $\mathbf{K}_{\mathbf{x}}$ & Half-saturation coefficient for hydrolysis of $X_{S}$ & 0.1 & g COD. $\mathrm{m}^{-3}$ \\
\hline \multicolumn{4}{|c|}{ Ammonification } \\
\hline $\mathbf{k}_{\mathrm{a}}$ & Rate constant for ammonification & 0.07 & $\mathrm{~m}^{3} \cdot \mathrm{g}^{-1} \mathrm{COD}_{\text {BIO }} \cdot \mathrm{d}^{-1}$ \\
\hline \multicolumn{4}{|c|}{ AOB denitrification } \\
\hline $\mathbf{K}_{\mathrm{SNO}, \mathrm{AOB}}$ & NO half saturation coefficient for AOB-mediated NO reduction & 1 & g N.m ${ }^{-3}$ \\
\hline $\mathrm{K}_{\text {SO,AOBden1 }}$ & $\mathrm{O}_{2}$ half saturation coefficient for $\mathrm{AOB}$-mediated $\mathrm{NO}_{2}$ - reduction & 11.4 & $\mathrm{~g}(-\mathrm{COD}) \cdot \mathrm{m}^{-3}$ \\
\hline $\mathrm{K}_{\text {IO,AOBden1 }}$ & $\mathrm{O}_{2}$ inhibition coefficient for AOB-mediated $\mathrm{NO}_{2}$ - reduction & 0.0351 & $\mathrm{~g}(-\mathrm{COD}) \cdot \mathrm{m}^{-3}$ \\
\hline $\mathrm{K}_{\text {SO,AOBden2 }}$ & $\mathrm{O}_{2}$ half saturation coefficient for AOB-mediated NO reduction & 11.4 & $\mathrm{~g}(-\mathrm{COD}) \cdot \mathrm{m}^{-3}$ \\
\hline $\mathrm{K}_{\mathrm{IO}, \mathrm{AOBden2}}$ & $\mathrm{O}_{2}$ inhibition coefficient for AOB-mediated NO reduction & 0.0351 & $\mathrm{~g}(-\mathrm{COD}) \cdot \mathrm{m}^{-3}$ \\
\hline $\mathbf{n}_{\mathrm{AOB}}$ & reduction factor for $\mathrm{AOB}$ growth on $\mathrm{NO}_{2}-/ \mathrm{NO}$ & 0.5 & {$[-]$} \\
\hline $\mathbf{K}_{\mathrm{FNA}, \mathrm{AOB}}$ & $\mathrm{HNO}_{2}$ half saturation coefficient for AOB-mediated $\mathrm{NO}_{2}$ - reduction & $6 \cdot 10-4$ & g N.m ${ }^{-3}$ \\
\hline $\mathbf{K}_{\mathrm{FA}, \mathrm{AOB}}$ & $\mathrm{NH}_{3}$ half saturation coefficient for AOB-mediated $\mathrm{NO}_{2}$ - and $\mathrm{NO}$ reduction & 0.0027 & g N.m ${ }^{-3}$ \\
\hline \multicolumn{4}{|c|}{ AnAOB activity } \\
\hline $\mathbf{Y}_{\mathrm{AnAOB}}$ & growth yield of AnAOB & 0.16 & $\mathrm{~g} \mathrm{COD}_{\text {ВІо. }} \cdot \mathrm{g}^{-1} \mathrm{~N}$ \\
\hline$\mu_{\mathrm{AnAOB}}$ & maximum specific growth rate of AnAOB & 0.0173 & $\mathrm{~d}^{-1}$ \\
\hline $\mathbf{K}_{\mathrm{NH} 3, \mathrm{AnAOB}}$ & $\mathrm{NH}_{3}$ half saturation coefficient for AnAOB activity & 0.0012 & g N.m ${ }^{-3}$ \\
\hline $\mathrm{K}_{\mathrm{HNO2,AnAOB}}$ & $\mathrm{HNO}_{2}$ half saturation coefficient for AnAOB activity & $2.81 \cdot 10-6$ & g N.m ${ }^{-3}$ \\
\hline
\end{tabular}




\begin{tabular}{|c|c|c|c|}
\hline $\mathbf{K}_{\mathrm{O} 2, \mathrm{AnAOB}}$ & $\mathrm{O}_{2}$ inhibition coefficient for AnAOB activity & 0.01 & $\mathrm{~g}(-\mathrm{COD}) \cdot \mathrm{m}^{-3}$ \\
\hline $\mathbf{b}_{\text {AnAOB }}$ & decay coefficient of AnAOB & $6.19 \cdot 10-4$ & $\mathrm{~d}^{-1}$ \\
\hline \multicolumn{4}{|c|}{ Other parameters } \\
\hline $\mathbf{f}_{\mathrm{P}}$ & fraction of $X_{P}$ generated from biomass decay & 0.08 & $\mathrm{~g} \mathrm{COD}_{\mathrm{XP}} \cdot \mathrm{g}^{-1} \mathrm{COD}_{\mathrm{BIO}}$ \\
\hline $\mathbf{i}_{\mathrm{XB}}$ & $\mathrm{N}$ content in biomass & 0.086 & $\mathrm{~g} \mathrm{~N} \mathrm{~g}^{-1}$ (COD) \\
\hline $\mathbf{i}_{X P}$ & $\mathrm{~N}$ content in $\mathrm{X}_{\mathrm{P}}$ & 0.06 & $\mathrm{~g} \mathrm{~N}_{\mathrm{g}} \mathrm{g}^{-1}(\mathrm{COD})$ \\
\hline
\end{tabular}

\section{Model for mainstream activated sludge processes in the BSM2Nb}

Table 5: (a) Stoichiometric matrix and (b) kinetic vector for AOB-mediated processes.

(a)

\begin{tabular}{|c|c|c|c|c|c|c|c|}
\hline \multicolumn{8}{|c|}{ Stoichiometric matrix } \\
\hline & $S_{N H X}$ & $S_{\mathrm{NH} 2 \mathrm{OH}}$ & $S_{O 2}$ & $S_{\mathrm{NO} 2}$ & $S_{N O}$ & $S_{N 2 O}$ & $X_{A O B}$ \\
\hline $\begin{array}{c}\text { Aerobic } \\
\text { oxidation of } \\
\mathrm{NH}_{X} \text { into } \\
\mathrm{NH}_{2} \mathrm{OH}\end{array}$ & -1 & 1 & -1.14 & & & & \\
\hline $\begin{array}{l}\text { Aerobic } \\
\text { growth of } \\
\text { AOB }\end{array}$ & $-i_{N X B}$ & $-\frac{1}{\mathrm{Y}_{\mathrm{AOB}}}$ & $-\frac{1.71-\mathrm{Y}_{\mathrm{AOB}}}{\mathrm{Y}_{\mathrm{AOB}}}$ & & $\frac{1}{\mathrm{Y}_{\mathrm{AOB}}}$ & & 1 \\
\hline $\begin{array}{c}\text { Aerobic } \\
\text { oxidation of } \\
\mathrm{NO} \text { into } \mathrm{NO}_{2}^{-} \\
\end{array}$ & & & -0.571 & 1 & -1 & & \\
\hline $\begin{array}{c}\mathrm{N}_{2} \mathrm{O} \\
\text { production by } \\
\text { Incomplete } \\
\text { NH2OH } \\
\text { oxidation } \\
\end{array}$ & & -1 & & 1 & -4 & 4 & \\
\hline $\begin{array}{c}\mathrm{N}_{2} \mathrm{O} \\
\text { production } \\
\text { due to } \mathrm{AOB} \\
\text { denitrification }\end{array}$ & & -1 & & -1 & & 2 & \\
\hline
\end{tabular}

(b)

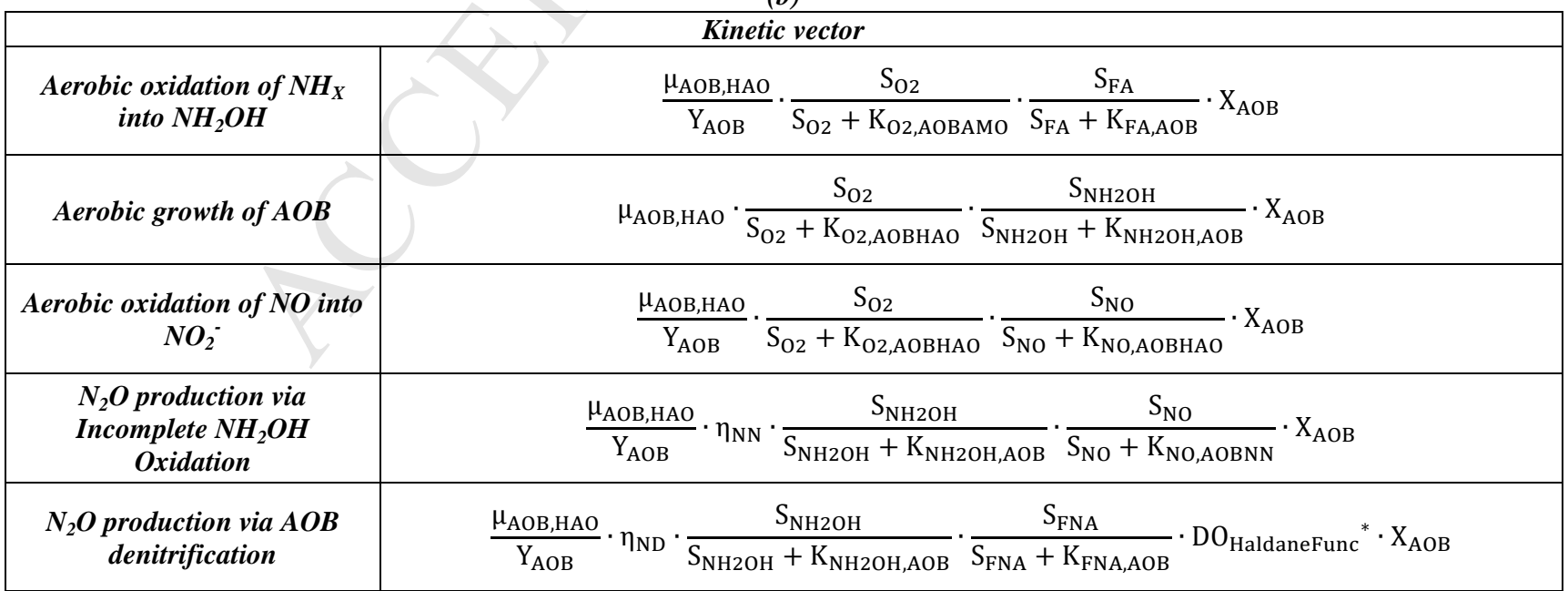

$$
\mathrm{DO}_{\text {HaldaneFunc }}{ }^{*}=\frac{\mathrm{S}_{\mathrm{O} 2}}{\mathrm{~K}_{\mathrm{SO} 2, \mathrm{AOBden}}+\left(1-2 \cdot \sqrt{\mathrm{K}_{\mathrm{SO} 2, \mathrm{AOBden}} / \mathrm{K}_{\mathrm{IO}, \mathrm{AOBden}}}\right) \cdot \mathrm{S}_{\mathrm{O} 2}+\mathrm{S}_{\mathrm{O} 2}{ }^{2} / \mathrm{K}_{\mathrm{IO}, \mathrm{AOBden}}}
$$


Table 6: Parameter values used in the BSM2Nb for the biological processes.

\begin{tabular}{|c|c|c|c|}
\hline$\overline{\mathbf{Y}_{\mathrm{AOB}}}$ & growth yield of AOB & 0.18 & $\mathrm{~g} \mathrm{COD}_{\mathrm{BIO}} \cdot \mathrm{g}^{-1} \mathrm{~N}$ \\
\hline$\mu_{\text {АОВ,НАО }}$ & maximum specific growth rate of $\mathrm{AOB}$ & 0.58 & $\mathrm{~d}^{-1}$ \\
\hline $\mathbf{i}_{\mathrm{N}, \mathbf{X B}}$ & $\mathrm{N}$ content of the biomass & 0.086 & g N.g ${ }^{-1}$ COD \\
\hline$\eta_{\mathrm{ND}}$ & Reduction factor for $\mathrm{AOB}$ denitrification rate & 0.25 & - \\
\hline$\eta_{\mathrm{NN}}$ & Reduction factor for the incomplete hydroxylamine oxidation rate & 0.0015 & - \\
\hline $\mathbf{K}_{\mathrm{FA}, \mathrm{AOB}}$ & Free ammonia affinity constant for aerobic AOB activity & 0.003 & g N.m ${ }^{-3}$ \\
\hline $\mathbf{K}_{\mathrm{NH} 2 \mathrm{OH}, \mathrm{AOB}}$ & Hydroxylamine affinity constant & 0.9 & $\mathrm{~g} \mathrm{~N} \cdot \mathrm{m}^{-3}$ \\
\hline $\mathrm{K}_{\mathrm{FNA,AOB}}$ & Free nitrous acid affinity constant for AOB denitrification & 0.178 & $\mathrm{~g} \mathrm{~N} \cdot \mathrm{m}^{-3}$ \\
\hline $\mathrm{K}_{\text {NO,АOВHAO }}$ & Nitric oxide affinity constant for aerobic AOB activity & $3 \cdot 10^{-4}$ & g N.m ${ }^{-3}$ \\
\hline $\mathbf{K}_{\mathrm{NO}, \mathrm{AOBNN}}$ & Nitric oxide affinity constant for incomplete $\mathrm{NH} 2 \mathrm{OH}$ oxidation & 0.008 & g N.m ${ }^{-3}$ \\
\hline $\mathbf{K}_{\text {IO,AOBden }}$ & Oxygen inhibition constant for AOB denitrification & 0.8 & $\mathrm{~g}(-\mathrm{COD}) \cdot \mathrm{m}^{-3}$ \\
\hline $\mathrm{K}_{\text {SO2,AOBden }}$ & Oxygen affinity constant for AOB denitrification & 0.5 & $\mathrm{~g}(-\mathrm{COD}) \cdot \mathrm{m}^{-3}$ \\
\hline $\mathbf{K}_{\text {O2,АОВАMO }}$ & Oxygen affinity constant for aerobic oxidation of ammonium to hydroxylamine & 1 & $\mathrm{~g}(-\mathrm{COD}) \cdot \mathrm{m}^{-3}$ \\
\hline $\mathbf{K}_{\text {O2,АОВамо }}$ & Oxygen affinity constant for aerobic oxidation of hydroxylamine to nitrite & 0.6 & $\mathrm{~g}(-\mathrm{COD}) \cdot \mathrm{m}^{-3}$ \\
\hline
\end{tabular}

For the NOB-mediated processes and for the HB-mediated processes, the model structure and the parameters are the ones used for the BSM2Na.

\section{Model for mainstream activated sludge processes in the BSM2Nc}

Table 7: Petersen matrix of the AOB-mediated processes.

\begin{tabular}{|c|c|c|c|c|c|c|c|}
\hline \multicolumn{8}{|c|}{ Stoichiometric matrix } \\
\hline & $S_{N H X}$ & $S_{\mathrm{NH} 2 \mathrm{OH}}$ & $S_{O 2}$ & $\mathrm{~S}_{\mathrm{NO} 2}$ & $S_{N O}$ & $S_{N 2 O}$ & $X_{A O B}$ \\
\hline $\begin{array}{c}\text { Aerobic } \\
\text { oxidation of } \\
\mathrm{NH}_{\mathrm{X}} \text { into } \\
\mathrm{NH}_{2} \mathrm{OH}\end{array}$ & -1 & (1) & & & & & \\
\hline $\begin{array}{l}\text { Aerobic growth } \\
\text { of AOB from } \\
\mathrm{NH}_{2} \mathrm{OH} \text { to } \mathrm{NO}_{2}^{-}\end{array}$ & $-i_{N X B}$ & $\frac{1}{\mathrm{Y}_{\mathrm{AOB}}}$ & $-\frac{2.29-\mathrm{Y}_{\mathrm{AOB}}}{\mathrm{Y}_{\mathrm{AOB}}}$ & $\frac{1}{\mathrm{Y}_{\mathrm{AOB}}}$ & & & 1 \\
\hline $\begin{array}{c}\text { Aerobic grow of } \\
\text { AOB from } \\
\mathrm{NH}_{2} \mathrm{OH} \text { to } \mathrm{NO}\end{array}$ & $-i_{N X B}$ & $\frac{1}{Y_{A O B}}$ & $-\frac{0.57-\mathrm{Y}_{\mathrm{AOB}}}{\mathrm{Y}_{\mathrm{AOB}}}$ & & $\frac{1}{\mathrm{Y}_{\mathrm{AOB}}}$ & & 1 \\
\hline $\begin{array}{c}\mathrm{AOB} \\
\text { denitrification } \\
\text { on } \mathrm{NO}_{2}^{-} \\
\end{array}$ & & -1 & & -3 & 4 & & \\
\hline $\begin{array}{c}A O B \\
\text { denitrification } \\
\text { on } N O\end{array}$ & 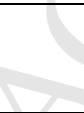 & -1 & & 1 & -4 & 4 & \\
\hline
\end{tabular}

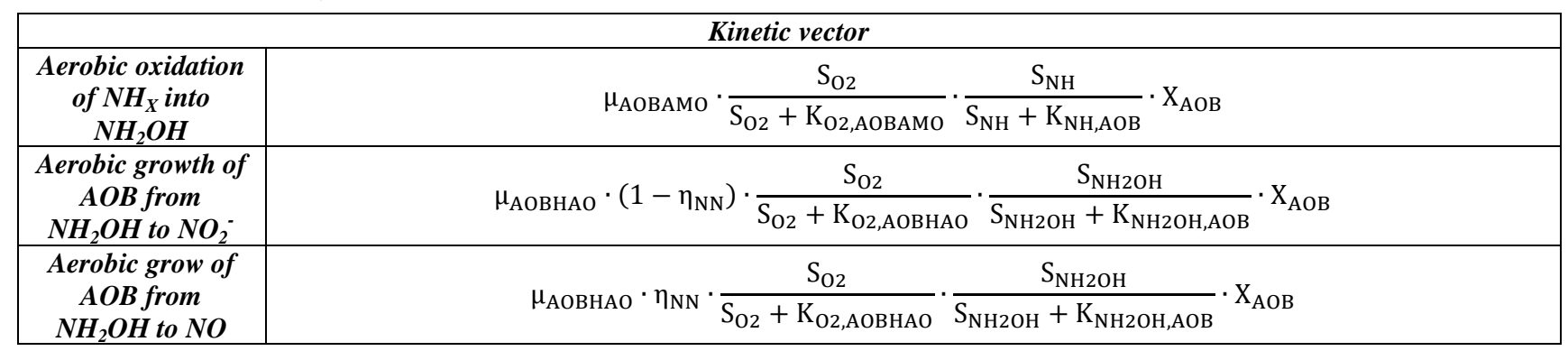




\begin{tabular}{|c|c|}
\hline $\begin{array}{c}\text { AOB } \\
\text { denitrification on } \\
\boldsymbol{N O}_{2}^{-}\end{array}$ & $\mu_{\mathrm{AOBHAO}} \cdot \eta_{\mathrm{ND}} \cdot \frac{\mathrm{K}_{\mathrm{IO}, \mathrm{AOBden}}}{\mathrm{K}_{\mathrm{IO}, \mathrm{AOBden}}+\mathrm{S}_{\mathrm{O} 2}} \cdot \frac{\mathrm{S}_{\mathrm{NH} 2 \mathrm{OH}}}{\mathrm{S}_{\mathrm{NH} 2 \mathrm{OH}}+\mathrm{K}_{\mathrm{NH} 2 \mathrm{OH}, \mathrm{AOB}}} \cdot \frac{\mathrm{S}_{\mathrm{NO} 2}}{\mathrm{~S}_{\mathrm{NO} 2}+\mathrm{K}_{\mathrm{NO} 2, \mathrm{AOB}}} \cdot \mathrm{X}_{\mathrm{AOB}}$ \\
\hline $\begin{array}{c}\boldsymbol{A O B} \\
\begin{array}{c}\text { denitrification on } \\
\text { NO }\end{array}\end{array}$ & $\mu_{\mathrm{AOBHAO}} \cdot \eta_{\mathrm{ND}} \cdot \frac{\mathrm{S}_{\mathrm{NH} 2 \mathrm{OH}}}{\mathrm{S}_{\mathrm{NH} 2 \mathrm{OH}}+\mathrm{K}_{\mathrm{NH} 2 \mathrm{OH}, \mathrm{AOB}}} \cdot \frac{\mathrm{S}_{\mathrm{NO}}}{\mathrm{S}_{\mathrm{NO}}+\mathrm{K}_{\mathrm{NO}, \mathrm{AOB}}} \cdot \mathrm{X}_{\mathrm{AOB}}$ \\
\hline
\end{tabular}

Table 8: Parameter values used in the BSM2Nc for the biological processes.

\begin{tabular}{|c|c|c|c|}
\hline $\mathbf{Y}_{\mathrm{AOB}}$ & growth yield of $\mathrm{AOB}$ & 0.18 & $\mathrm{~g} \mathrm{COD}_{\mathrm{BIO}} \cdot \mathrm{g}^{-1} \mathrm{~N}$ \\
\hline $\boldsymbol{\mu}_{\text {АОВамо }}$ & Maximal specific oxidation rate for aerobic oxidation of ammonium to hydroxylamine & 4.38 & $\mathrm{~d}^{-1}$ \\
\hline $\boldsymbol{\mu}_{\text {АОВНАО }}$ & Maximal specific oxidation rate for hydroxylamine oxidation & 2.016 & $\mathrm{~d}^{-1}$ \\
\hline $\mathbf{i}_{\mathrm{N}, \mathrm{XB}}$ & $\mathrm{N}$ content of the biomass & $0.086 \quad$ & g N.g ${ }^{-1}$ COD \\
\hline$\eta_{\mathrm{ND}}$ & Reduction factor for $\mathrm{AOB}$ denitrification rate & 0.56 & - \\
\hline$\eta_{\mathrm{NN}}$ & Reduction factor for the incomplete hydroxylamine oxidation rate & 0.0013 & - \\
\hline $\mathbf{K}_{\mathrm{NH} 4, \mathrm{AOB}}$ & Ammonium affinity constant for AOB & 0.15 & g N.m ${ }^{-3}$ \\
\hline $\mathbf{K}_{\mathrm{NH} 2 \mathrm{OH}, \mathrm{AOB}}$ & Hydroxylamine affinity constant for AOB & 1 & g N.m ${ }^{-3}$ \\
\hline $\mathbf{K}_{\mathrm{NO2,AOB}}$ & Nitrite affinity constant for AOB denitrification & 0.8 & g N.m ${ }^{-3}$ \\
\hline $\mathbf{K}_{\mathrm{NO}, \mathrm{AOB}}$ & Nitric oxide affinity constant for AOB denitrification & 0.02 & g N.m ${ }^{-3}$ \\
\hline $\mathbf{K}_{\text {О2,АОВАМО }}$ & Oxygen affinity constant for aerobic oxidation of ammonium to hydroxylamine & 0.4 & $\mathrm{~g}(-\mathrm{COD}) \cdot \mathrm{m}^{-3}$ \\
\hline $\mathbf{K}_{\text {O2,АОВНАО }}$ & Oxygen affinity constant for aerobic oxidation of hydroxylamine to nitrite & 0.073 & $\mathrm{~g}(-\mathrm{COD}) \cdot \mathrm{m}^{-3}$ \\
\hline $\mathbf{K}_{\mathrm{IO}, \mathrm{AOBden}}$ & Oxygen inhibition constant for AOB denitrification & 0.15 & $\mathrm{~g}(-\mathrm{COD}) \cdot \mathrm{m}^{-3}$ \\
\hline
\end{tabular}

For the NOB-mediated processes and for the HB-mediated processes, the model structure and the parameters are the ones used for the BSM2Na. 


\section{APPENDIX A4}

Considering that the sample time used is equal to 15 minutes, and that the evaluation starts from day 244 to 609 , the performance criteria used to evaluate the control strategies are calculated in a discretized procedure as follows:

$-\mathrm{R}_{\text {NatAmm }}:$

$$
R_{\text {NatAmm }}=\frac{1}{35041} \cdot \sum_{i=23425}^{58465} \frac{\left.N O_{3}^{-}\right|_{\text {OUT, } i}-\left.N O_{3}^{-}\right|_{I N, i}}{\left.N H_{4}^{+}\right|_{I N, i}-\left.N H_{4}^{+}\right|_{\text {OUT }, i}}
$$

- Integral Absolute Error for $\mathrm{R}_{\mathrm{NatAmm}}$ :

$$
I A E_{\text {RNatAmm }}=\sum_{i=23425}^{58465}\left|R_{\text {NatAmmSP }, i}-R_{\text {NatAmm }, i}\right|
$$

- Integral Square Error for $\mathrm{R}_{\mathrm{NatAmm}}$ :

$$
I S E_{\text {RNatAmm }}=\sum_{i=23425}^{58465}\left(R_{\text {NatAmmSP }, i}-R_{\text {NatAmm }, i}\right)^{2}
$$

- Total Variation (TV) of $\mathrm{k}_{\mathrm{L}} \mathrm{a}$, calculated by summing the TV of the three $\mathrm{k}_{\mathrm{L}} \mathrm{a}$ in the aerobic zone :

$$
T V_{k_{L} a}=\sum_{i=23425}^{58465}\left|k_{L} a_{i+1}-k_{L} a_{i}\right|
$$

- $\mathrm{N}_{2} \mathrm{O}$ emission factor, calculated per unit of influent TKN $\left[\mathrm{g} \mathrm{N}_{2} \mathrm{O}-\mathrm{N} \cdot \mathrm{g}^{-1} \mathrm{TKN}_{\text {in }}\right]$ :

$$
N_{2} O_{e f 1}=\frac{\sum_{i=23425}^{58465}\left(N_{2} O_{A N O X 1, i}+N_{2} O_{A N O X 2, i}+N_{2} O_{A E R 1, i}+N_{2} O_{A E R 2, i}+N_{2} O_{A E R 3, i}\right)}{\sum_{i=234455}^{5865}\left(\left(S_{N H i n, i}+S_{N D i n, i}+X_{N D i n, i}\right) \cdot Q_{i n, i}\right)}
$$

- $\mathrm{N}_{2} \mathrm{O}$ emission factor, calculated per unit of removed TKN $\left[\mathrm{g} \mathrm{N}_{2} \mathrm{O}-\mathrm{N} \cdot \mathrm{g}^{-1} \mathrm{TKN}_{\mathrm{rem}}\right]$ ),

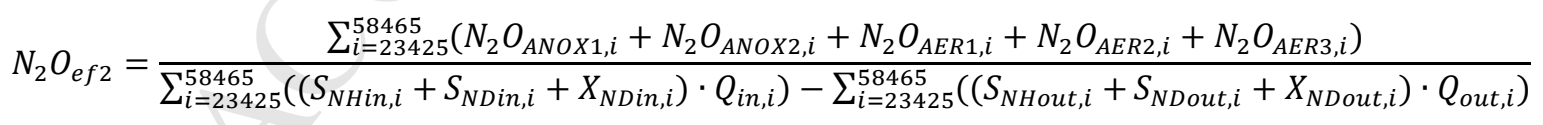

- $\mathrm{N}_{2} \mathrm{O}$ produced according to HB denitrification in the aerobic zone (third HB denitrification step) [g $\left.\mathrm{N}_{2} \mathrm{O}-\mathrm{N} \cdot \mathrm{d}^{-1}\right]$ :

$$
\frac{1}{35041} \cdot \sum_{\mathrm{i}=23425}^{58465}\left(\sum_{\mathrm{j}=1}^{3}\left(\frac{1-\mathrm{Y}_{\mathrm{H}} \cdot \mathrm{n}_{\mathrm{Y}}}{0.571 \cdot \mathrm{Y}_{\mathrm{H}} \cdot \mathrm{n}_{\mathrm{Y}}}\right) \cdot \mu_{\mathrm{HB}, \mathrm{T}} \cdot \eta_{\mathrm{AnoxHB}, 4} \cdot \frac{\mathrm{S}_{\mathrm{S}, \mathrm{j}}}{\mathrm{S}_{\mathrm{S}, \mathrm{j}}+\mathrm{K}_{\mathrm{S} 4}} \cdot \frac{\mathrm{K}_{\mathrm{OH} 4}}{\mathrm{~S}_{\mathrm{O} 2, \mathrm{j}}+\mathrm{K}_{\mathrm{OH} 4}} \cdot \frac{\mathrm{S}_{\mathrm{NO}, \mathrm{j}}}{S_{\mathrm{NO}, \mathrm{j}}+\mathrm{K}_{\mathrm{NO}}+\mathrm{S}_{\mathrm{NO}, \mathrm{j}} / \mathrm{K}_{\mathrm{I} 4 \mathrm{NO}}} \cdot \mathrm{X}_{\mathrm{HB}, \mathrm{j}} \cdot \mathrm{V}_{\mathrm{j}}\right)_{\mathrm{i}}
$$


- $\mathrm{N}_{2} \mathrm{O}$ consumed according to $\mathrm{HB}$ denitrification in the aerobic zone (fourth $\mathrm{HB}$ denitrification step) [g $\left.\mathrm{N}_{2} \mathrm{O}-\mathrm{N} \cdot \mathrm{d}^{-1}\right]$ :

$\frac{1}{35041} \cdot \sum_{i=23425}^{58465}\left(\sum_{j=1}^{3}\left(\frac{1-Y_{H} \cdot n_{Y}}{0.571 \cdot Y_{H} \cdot n_{Y}}\right) \cdot \mu_{H B, T} \cdot \eta_{A n o x H B, 5} \cdot \frac{S_{S, j}}{S_{S, j}+K_{S 5}} \cdot \frac{K_{O H 5}}{S_{O 2, j}+K_{O H 5}} \cdot \frac{S_{N 2 O, j}}{S_{N 2 O, j}+K_{N 2 O}} \cdot \frac{K_{I 5, N O}}{K_{I 5, N O}+S_{N O, j}} \cdot X_{H B, j} \cdot V_{j}\right)_{i}$

- $\mathrm{N}_{2} \mathrm{O}$ produced according to AOB denitrification in the BSM2Na $\left[\mathrm{g} \mathrm{N}_{2} \mathrm{O}-\mathrm{N} \cdot \mathrm{d}^{-1}\right]$ :

$\frac{1}{35041} \cdot \sum_{\mathrm{i}=23425}^{58465}\left(\sum_{\mathrm{j}=1}^{3} \frac{2}{\mathrm{Y}_{\mathrm{AOB}}} \cdot \mu_{\mathrm{AOB}, \mathrm{T}} \cdot \eta_{\mathrm{AnoxAOB}} \cdot \mathrm{DO}_{\text {HaldaneFunc,j }} * \frac{\mathrm{S}_{\mathrm{FA}, \mathrm{j}}}{\mathrm{S}_{\mathrm{FA}, \mathrm{j}}+\mathrm{K}_{\mathrm{FA}, \mathrm{AOB}}} \cdot \frac{\mathrm{S}_{\mathrm{NO}, \mathrm{j}}}{\mathrm{S}_{\mathrm{NO}, \mathrm{j}}+\mathrm{K}_{\mathrm{NO}, \mathrm{AOB}}} \cdot \mathrm{X}_{\mathrm{AOB}, \mathrm{j}} \cdot \mathrm{V}_{\mathrm{j}}\right)_{\mathrm{i}}$

- $\mathrm{N}_{2} \mathrm{O}$ produced according to AOB denitrification in the BSM2Nb $\left[\mathrm{g} \mathrm{N}_{2} \mathrm{O}-\mathrm{N} \cdot \mathrm{d}^{-1}\right.$ ]:

$$
\frac{1}{35041} \cdot \sum_{\mathrm{i}=23425}^{58465}\left(2 \cdot \frac{\mu_{\mathrm{AOB}, \mathrm{HAO}}}{\mathrm{Y}_{\mathrm{AOB}}} \cdot \eta_{\mathrm{ND}} \cdot \frac{\mathrm{S}_{\mathrm{NH} 2 \mathrm{OH}, \mathrm{j}}}{\mathrm{S}_{\mathrm{NH} 2 \mathrm{OH}, \mathrm{j}}+\mathrm{K}_{\mathrm{NH} 2 \mathrm{OH}, \mathrm{AOB}}} \cdot \frac{\mathrm{S}_{\mathrm{FNA}, \mathrm{j}}}{\mathrm{S}_{\mathrm{FNA}, \mathrm{j}}+\mathrm{K}_{\mathrm{FNA}, \mathrm{AOB}}} \cdot \mathrm{DO}_{\mathrm{HaldaneFunc,j}}{ }^{*} \cdot \mathrm{X}_{\mathrm{AOB}, \mathrm{j}} \cdot \mathrm{V}_{\mathrm{j}}\right)_{\mathrm{i}}
$$

- $\mathrm{N}_{2} \mathrm{O}$ produced by AOB in the BSM2Nc $\left[\mathrm{g} \mathrm{N}_{2} \mathrm{O}-\mathrm{N} \cdot \mathrm{d}^{-1}\right]$ :

$$
\frac{1}{35041} \cdot \sum_{\mathrm{i}=23425}^{58465}\left(4 \cdot \mu_{\mathrm{AOBHAO}} \cdot \eta_{\mathrm{ND}} \cdot \frac{\mathrm{S}_{\mathrm{NH} 2 \mathrm{OH}, \mathrm{j}}}{\mathrm{S}_{\mathrm{NH} 2 \mathrm{OH}, \mathrm{j}}+\mathrm{K}_{\mathrm{NH} 2 \mathrm{OH}, \mathrm{AOB}}} \cdot \frac{\mathrm{S}_{\mathrm{NO}, \mathrm{j}}}{S_{\mathrm{NO}, \mathrm{j}}+\mathrm{K}_{\mathrm{NO}, \mathrm{AOB}}} \cdot \mathrm{X}_{\mathrm{AOB}, \mathrm{j}} \cdot \mathrm{V}_{\mathrm{j}}\right)_{\mathrm{i}}
$$

- $\mathrm{N}_{2} \mathrm{O}$ produced according to incomplete $\mathrm{NH}_{2} \mathrm{OH}$ oxidation in the BSM2Nb $\left[\mathrm{g} \mathrm{N}_{2} \mathrm{O}-\mathrm{N} \cdot \mathrm{d}^{-1}\right]$ :

$$
\frac{1}{35041} \cdot \sum_{\mathrm{i}=23425}^{58465}\left(4 \cdot \frac{\mu_{\mathrm{AOB}, \mathrm{HAO}}}{\mathrm{Y}_{\mathrm{AOB}}} \cdot \eta_{\mathrm{NN}} \cdot \frac{\mathrm{S}_{\mathrm{NH} 2 \mathrm{OH}}}{\mathrm{S}_{\mathrm{NH} 2 \mathrm{OH}}+\mathrm{K}_{\mathrm{NH} 2 \mathrm{OH}, \mathrm{AOB}}} \cdot \frac{\mathrm{S}_{\mathrm{NO}}}{\mathrm{S}_{\mathrm{NO}}+\mathrm{K}_{\mathrm{NO}, \mathrm{AOBNN}}} \cdot \mathrm{X}_{\mathrm{AOB}} \cdot \mathrm{V}_{\mathrm{j}}\right)_{\mathrm{i}}
$$

- TKN removal efficiency :

$$
\eta_{T K N}=\frac{\overline{T K N_{\text {ln }}}-\overline{T K N_{\text {out }}}}{\overline{T K N_{\text {ln }}}}
$$

- TN removal efficiency $\left(\eta_{\mathrm{TN}}\right)$ :

$$
\eta_{T N}=\frac{\overline{T N_{\iota n}}-\overline{T N_{o u t}}}{\overline{T N_{\iota n}}}
$$

- Effluent nitrate $\left[\mathrm{g} \mathrm{N} \cdot \mathrm{m}^{-3}\right]$ :

$$
\overline{\left[N O_{3}^{-}\right]_{e f f}}=\frac{\sum_{i=23425}^{58465}\left(\left[N O_{3, e f f}^{-}\right]_{i} \cdot Q_{e f f, i} \cdot t_{i}\right)}{\sum_{i=23425}^{58465} Q_{e f f, i}}
$$

- Percentage of total time when effluent ammonium violations occur :

$$
V_{N H}=\frac{\text { number of times }\left(\left[N H_{4, \text { eff }}^{+}\right]>\left[N H_{4}^{+}\right]_{\text {lim }}\right) \cdot \text { sampletime }}{t(i=58465)-t(i=23425)}
$$


- Percentage of total time when effluent total nitrogen violations occur :

$$
V_{T N}=\frac{\text { number of times }\left(\left[T N_{\text {eff }}\right]>[T N]_{\text {lim }}\right) \cdot \text { sampletime }}{t(i=58465)-t(i=23425)}
$$

- Effluent quality index [kg pollutant.units. $\left.\mathrm{d}^{-1}\right]$ :

$$
E Q I=\frac{\sum_{i=23425}^{58465}\left(\left(72 \cdot \operatorname{TSS}_{e}(i)+\operatorname{COD}_{e}(i)+20 \cdot T K N_{e}(i)+20 \cdot N O_{3, e}^{-}(i)+2 \cdot B O D_{5, e}(i)\right) \cdot t_{i}\right)}{(t(i=58465)-t(i=23425)) \cdot 1000}
$$

- Average aeration energy consumed $\left[\mathrm{kWh} . \mathrm{d}^{-1}\right]$ :

$$
A E C=\frac{\int_{t_{\text {start }}}^{t_{\text {end }}} \sum_{i=1}^{5} V_{i} \cdot k_{L} a_{i}(t) \cdot\left(S_{O 2, \text { sat }}-S_{O 2, i}(t)\right) \cdot d t}{1.8 \cdot 1000 \cdot\left(t_{\text {end }}-t_{\text {start }}\right)}
$$




\section{APPENDIX A5}

Proportional integral ammonium cascade controller

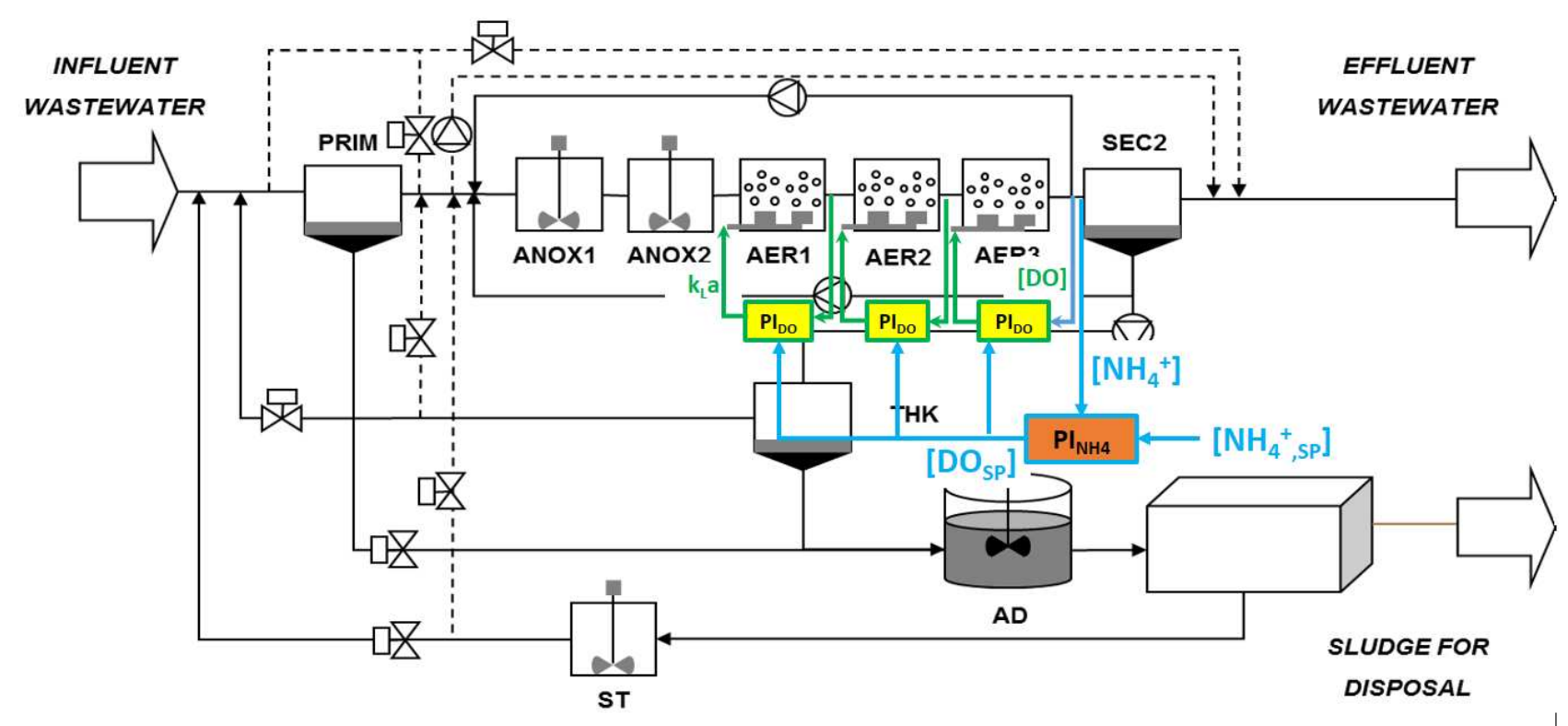




\section{APPENDIX A6}

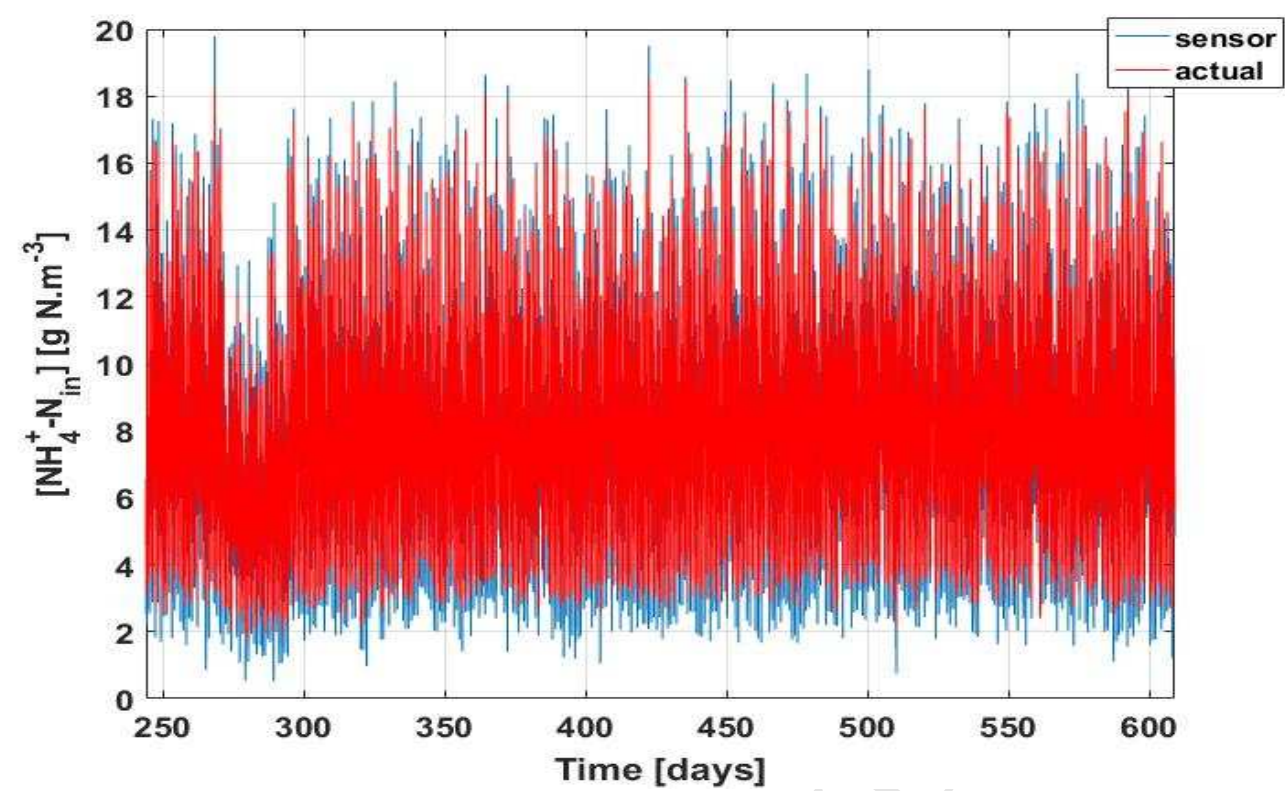

Figure A6.1: Ammonium concentration inlet to the first aerobic tank (AER1): actual value (in red) and with measurement noise (in blue).

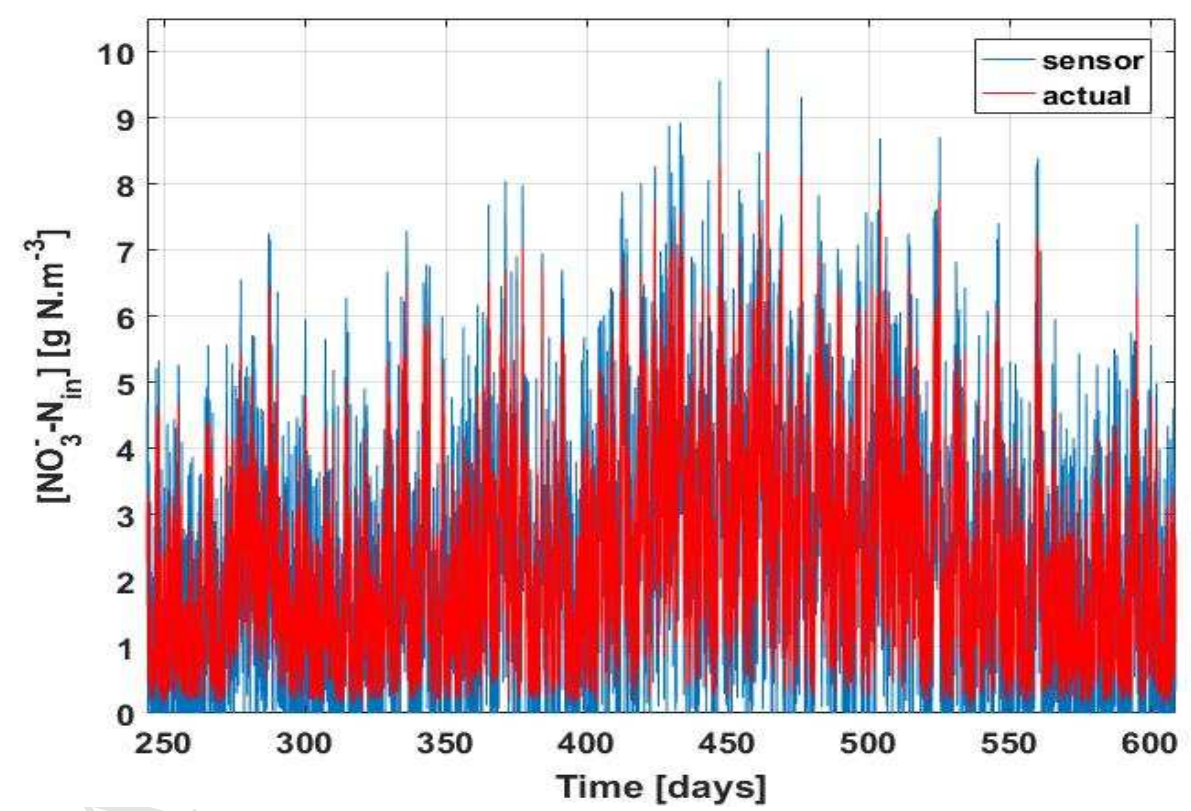

Figure A6.2: Nitrate concentration inlet to the first aerobic tank (AER1): actual value (in red) and with measurement noise (in blue). 


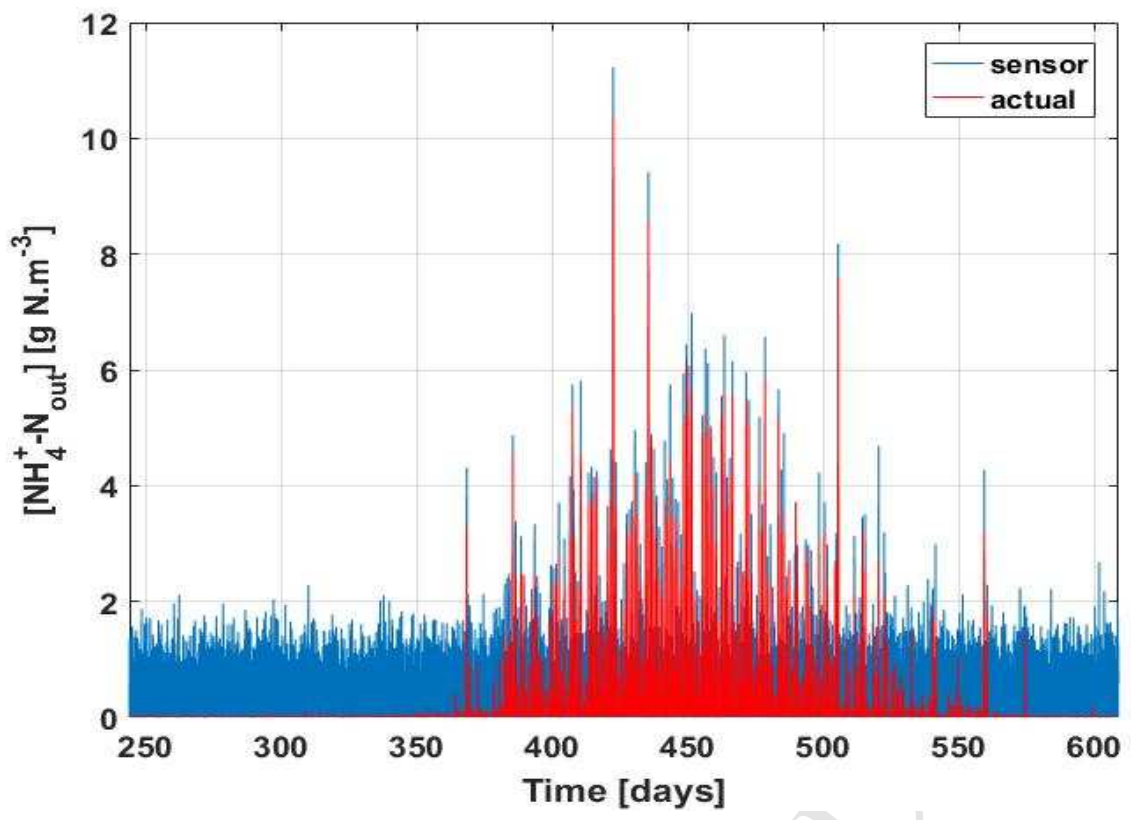

Figure A6.3: Ammonium concentration outlet to the first aerobic tank (AER1): actual value (in red) and with measurement noise (in blue).

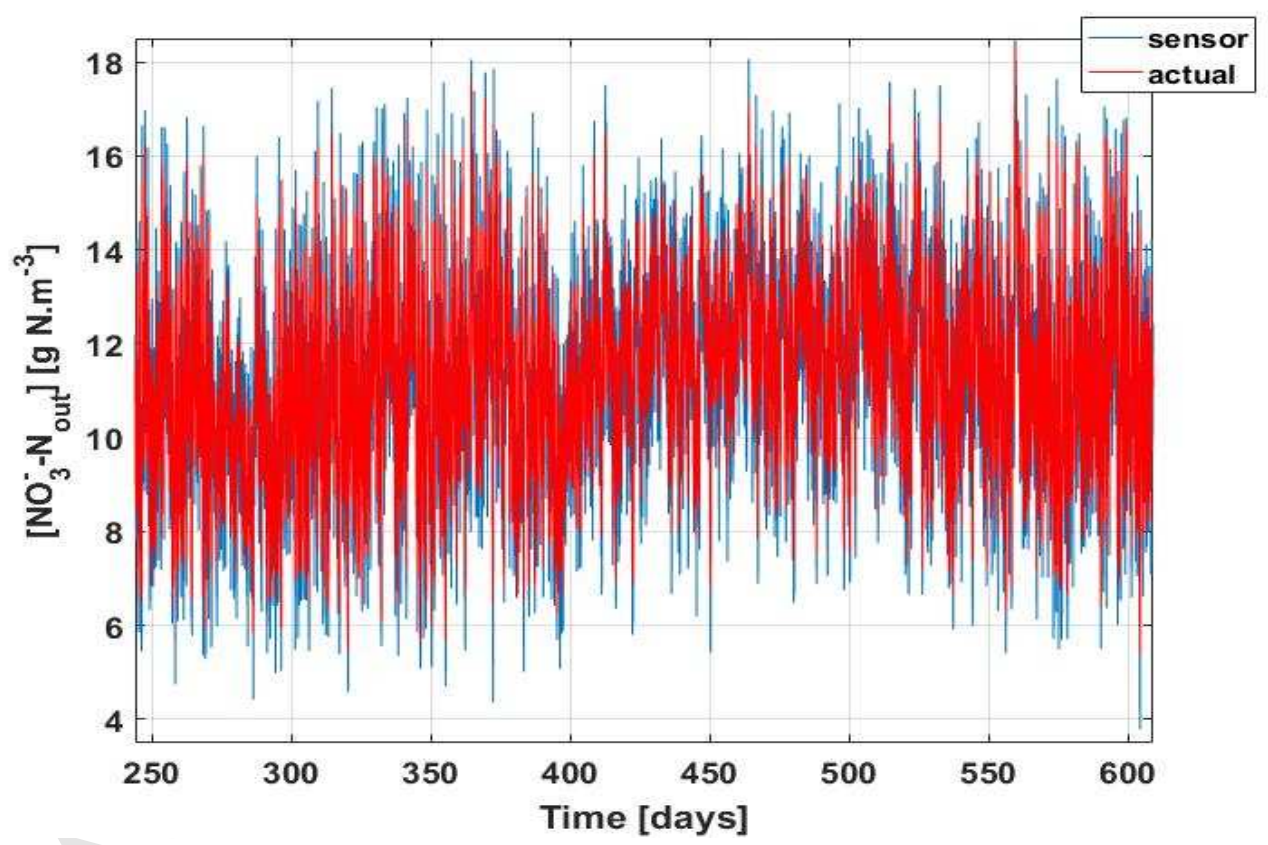

Figure A6.4: Nitrate concentration outlet to the first aerobic tank (AER1): actual value (in red) and with measurement noise (in blue). 


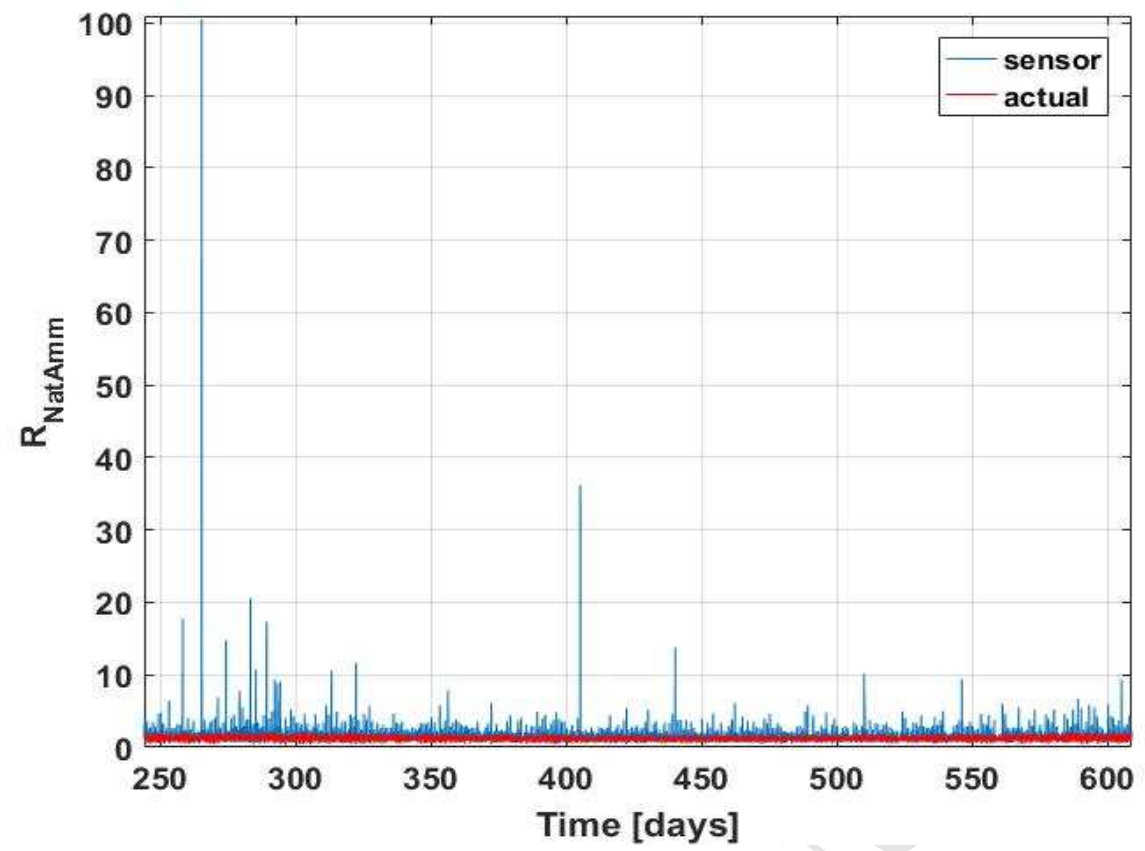

Figure A6.5: Ratio between nitrate produced and ammonium removed in the aerobic zone: actual value (in red) and with measurement noise (in blue). 


\begin{tabular}{|c|c|c|c|}
\hline Scenario $\downarrow$ & $\begin{array}{c}\text { net } \mathbf{N}_{\mathbf{2}} \mathbf{O} \text { prod. by AOB and HB } \\
\text { in aerobic zone }\end{array}$ & $\begin{array}{c}\text { net } \mathbf{N}_{\mathbf{2}} \mathbf{O} \text { prod. by HB } \\
\text { in anoxic zone }\end{array}$ & {$\left[\mathbf{N H}_{\mathbf{4}}{ }^{+}\right]_{\text {eff }}$} \\
\hline $\mathbf{1}$ & LOW & LOW & HIGH \\
\hline $\mathbf{2}$ & HIGH & LOW & LOW \\
\hline $\mathbf{3}$ & LOW & HIGH & LOW \\
\hline $\mathbf{4}$ & HIGH & LOW & HIGH \\
\hline $\mathbf{5}$ & LOW & HIGH & HIGH \\
\hline
\end{tabular}




\begin{tabular}{|c|c|}
\hline TEMPERATURE $\left[{ }^{\mathbf{}} \mathbf{C}\right]$ & $\mathbf{R}_{\text {NatAmm,SP }}$ \\
\hline 10 & 1.1 \\
\hline 15 & 1.2 \\
\hline 20 & 1.4 \\
\hline
\end{tabular}




\begin{tabular}{|c|c|c|c|c|}
\cline { 3 - 5 } \multicolumn{2}{|c|}{} & \multicolumn{3}{c|}{ E $_{\text {RNatAmm }}$} \\
\cline { 3 - 5 } \multicolumn{2}{|c|}{} & LOW & GOOD & HIGH \\
\hline \multirow{2}{*}{$\left(\mathrm{NH}_{4}{ }^{+}\right)_{\text {eff }}$} & GOOD & $N$ & $Z$ & $P$ \\
\cline { 2 - 5 } & HIGH & $P$ & $P$ & $P$ \\
\hline
\end{tabular}

Legend: P=POSITIVE, N=NEGATIVE, Z= ZERO. 


\begin{tabular}{|c|c|}
\hline TEMPERATURE & RER \\
\hline VERY LOW & VER LOW \\
\hline LOW & LOW \\
\hline MEDIUM & MEDIUM \\
\hline HIGH & HIGH \\
\hline VERY HIGH & VERY HIGH \\
\hline
\end{tabular}




\begin{tabular}{|c|c|c|c|c|c|c|c|c|c|c|c|c|c|}
\hline & \multirow[b]{2}{*}{ BSM2N $\rightarrow$} & \multicolumn{3}{|c|}{ CS1 } & \multicolumn{3}{|c|}{ CS2 } & \multicolumn{3}{|c|}{ CS3 } & \multicolumn{3}{|c|}{ CS4 } \\
\hline & & $\mathbf{a}$ & b & c & $\mathbf{a}$ & b & c & $\mathbf{a}$ & b & c & $\mathbf{a}$ & $\mathbf{b}$ & c \\
\hline $\mathbf{R}_{\text {NatAmm }}$ & $\frac{\mathrm{g} \mathrm{N}_{3}^{-}-\mathrm{N}}{\mathrm{g} \mathrm{NH}_{4}^{+}-\mathrm{N}}$ & 1.2 & 1.265 & 1.17 & 1.26 & 1.28 & 1.24 & 1.27 & 1.28 & 1.26 & 1.27 & 1.28 & 1.256 \\
\hline $\mathbf{I A E}_{\mathrm{RNatAmm}}$ & {$[-]$} & 79.3 & 83.5 & 92.97 & 73.84 & 77.56 & 84.23 & 73.62 & 76.82 & 83 & 74.06 & 77.16 & 85.1 \\
\hline ISE $_{\text {RNatAmm }}$ & {$[-]$} & 26.84 & 29.71 & 35.84 & 24 & 26.19 & 30.74 & 23.68 & 25.51 & 29.78 & 23.94 & 25.65 & 31.21 \\
\hline TV & {$\left[\mathrm{d}^{-1}\right]$} & 2733.4 & 2909.8 & 2779.8 & 1543.2 & 1685.4 & 1681.9 & 3021.2 & 2985.3 & 3331.8 & 5668.5 & 5688.2 & 6309.7 \\
\hline $\mathrm{N}_{2} \mathrm{O}_{\text {ef1 }}$ & $\% \frac{\mathrm{g} \mathrm{N}_{2} \mathrm{O}-\mathrm{N}_{\mathrm{gas}}}{\mathrm{gTKN}-\mathrm{N}_{\mathrm{in}}}$ & 0.16 & 0.0176 & 0.167 & 0.066 & 0.0248 & 0.067 & 0.045 & 0.0208 & 0.047 & 0.047 & 0.0226 & 0.049 \\
\hline $\mathrm{N}_{2} \mathrm{O}_{\mathrm{ef} 2}$ & $\% \frac{\mathrm{g} \mathrm{N}_{2} \mathrm{O}-\mathrm{N}_{\mathrm{gas}}}{\mathrm{g} \mathrm{TKN}-\mathrm{N}_{\mathrm{rem}}}$ & 0.166 & 0.0184 & 0.172 & 0.068 & 0.026 & 0.069 & 0.047 & 0.0217 & 0.048 & 0.049 & 0.0234 & 0.051 \\
\hline $\mathrm{N}_{2} \mathrm{O}$ produced by $\mathrm{HB}$ & $\frac{\mathrm{g} \mathrm{N}_{2} \mathrm{O}-\mathrm{N}_{\mathrm{liq}}}{\mathrm{d}}$ & -2446 & -785.3 & -36377 & -655.3 & -607.5 & -10589 & $\mid-825.4$ & -640.3 & -4408 & -659.5 & -609.7 & -5976 \\
\hline $\begin{array}{c}\mathrm{N}_{2} \mathrm{O} \text { produced from } \mathrm{AOB} \\
\text { denitrification }\end{array}$ & $\frac{\mathrm{g} \mathrm{N}_{2} \mathrm{O}-\mathrm{N}_{\mathrm{liq}}}{\mathrm{d}}$ & 3554.2 & 9.4 & & 725.9 & 5.7 & & 673.3 & 4.18 & & 522.3 & 3.36 & \\
\hline $\begin{array}{c}\mathrm{N}_{2} \mathrm{O} \text { produced from } \\
\text { incomplete } \mathrm{NH}_{2} \mathrm{OH} \\
\text { oxidation }\end{array}$ & $\frac{\mathrm{g} \mathrm{N}_{2} \mathrm{O}-\mathrm{N}_{\mathrm{liq}}}{\mathrm{d}}$ & I & 371.2 & 36881 & & 269.82 & 10945 & I & 252.1 & 5477.3 & I & 236.53 & 7528.4 \\
\hline
\end{tabular}




\begin{tabular}{|c|c|c|c|c|c|c|c|c|c|c|c|c|c|}
\hline \multirow{2}{*}{\multicolumn{2}{|c|}{ BSM2N $\rightarrow$}} & \multicolumn{3}{|c|}{ CS1 } & \multicolumn{3}{|c|}{$\mathrm{CS} 2$} & \multicolumn{3}{|c|}{ CS3 } & \multicolumn{3}{|c|}{ CS4 } \\
\hline & & $\mathbf{a}$ & b & c & $\mathbf{a}$ & $\mathbf{b}$ & c & $\mathbf{a}$ & b & c & $\mathbf{a}$ & b & c \\
\hline$\eta_{\text {TKN }}$ & $\% \frac{\mathrm{g} \mathrm{TKN}_{\text {rem }}}{\text { g TKN }_{\text {in }}}$ & 96.1 & 95.6 & 96.96 & 96.30 & 95.70 & 96.80 & 96.35 & 95.90 & 97.14 & 96.50 & 96.24 & 97.00 \\
\hline$\eta_{\mathrm{TN}}$ & $\% \frac{\mathrm{g} \mathrm{TN}_{\mathrm{rem}}}{\mathrm{g} \mathrm{TN}_{\mathrm{in}}}$ & 69.8 & 67.3 & 76.2 & 67.30 & 67.00 & 74.32 & 66.76 & 66.73 & 73.63 & 66.64 & 66.88 & 74.40 \\
\hline $\mathrm{NO}_{3}^{-}$ & g N. $\mathrm{m}^{-3}$ & 13.07 & 14.1 & 10.32 & 14.42 & 14.18 & 11.19 & 14.72 & 14.52 & 11.70 & 14.84 & 14.61 & 11.24 \\
\hline $\mathbf{V}_{\mathrm{NH}}$ & $\%$ of operating time & 0.054 & 0.11 & 0.077 & 1.71 & 4.60 & 1.54 & 0.58 & 2.44 & 0.38 & 0.40 & 0.95 & 0.44 \\
\hline $\mathbf{V}_{\mathrm{TN}}$ & $\%$ of operating time & 22.8 & 30.76 & 1.24 & 29.94 & 35.70 & 1.45 & 35.13 & 36.84 & 2.05 & 36.30 & 34.63 & 1.30 \\
\hline EQI & kg pollutant.units. $\mathrm{d}^{-1}$ & 5713.8 & 6069.1 & 2864.9 & 5928.3 & 6081.4 & 5087 & 5967 & 6060.04 & 5089.0 & 5957.2 & 5979.1 & 5042.9 \\
\hline
\end{tabular}




\begin{tabular}{|c|c|c|c|c|}
\hline \multicolumn{5}{|c|}{ AEC $\left[\mathbf{k W h . d} \mathbf{d}^{-\mathbf{1}}\right]$} \\
\hline BSM2Na & CS1 & CS2 & CS3 & CS4 \\
\hline BSM2Nb & 2935.1 & 3276.7 & 3133.6 & 3172.6 \\
\hline BSM2Nc & 2827.139 & 3194.62 & 3068.3 & 3129.95 \\
\hline
\end{tabular}


ACCEPTED MANUSCRIPT

\begin{tabular}{|c|c|c|c|c|c|c|}
\hline \multirow[b]{2}{*}{ scenario } & \multicolumn{2}{|c|}{$\begin{array}{c}\text { Oxygen affinity } \\
\text { values for } \mathrm{AOB} / \mathrm{NOB}\end{array}$} & \multicolumn{3}{|c|}{ Controller output and performance } & \multirow{3}{*}{ REFERENCE } \\
\hline & $\overline{\mathbf{K}_{\mathbf{O} 2, \mathrm{AOB}}}$ & $\mathbf{K}_{\mathrm{O} 2, \mathrm{NOB}}$ & $\mathbf{N}_{2} \mathbf{O}_{\text {ef1 }}$ & $\mathrm{N}_{2} \mathrm{O}_{\text {ef2 }}$ & $\mathbf{R}_{\text {NatAmm }}$ & \\
\hline & $\begin{array}{c}\mathrm{g}(- \\
\mathrm{COD}) \cdot \mathrm{m}^{-3}\end{array}$ & $\begin{array}{c}\mathrm{g}(- \\
\operatorname{COD}) \cdot \mathrm{m}^{-3}\end{array}$ & $\begin{array}{c}{\left[\% \mathrm{~g} \mathrm{~N}_{2} \mathrm{O}-\mathrm{N} \cdot \mathrm{g}^{-1}\right.} \\
\left.\mathbf{N}_{\text {in }}\right]\end{array}$ & $\begin{array}{c}{\left[\% \mathrm{~g} \mathrm{~N}_{2} \mathrm{O}-\mathrm{N} \cdot \mathrm{g}^{-1}\right.} \\
\left.\mathbf{N}_{\mathrm{rem}}\right]\end{array}$ & {$[-]$} & \\
\hline CS1 & \multirow{2}{*}{0.25} & \multirow[t]{2}{*}{1.84} & 7.71 & 7.96 & 0.74 & \multirow{2}{*}{ Peeters et al. (1969) } \\
\hline CS3 & & & 0.569 & 0.586 & 1.25 & \\
\hline CS1 & \multirow{2}{*}{0.5} & \multirow{2}{*}{2} & 6.2 & 6.42 & 0.72 & \multirow{2}{*}{ Laudelout et al. (1974) } \\
\hline CS3 & & & 0.364 & 0.377 & 1.25 & \\
\hline CS1 & \multirow{2}{*}{0.18} & \multirow{2}{*}{0.13} & 0.0131 & 0.0135 & 1.28 & \multirow{2}{*}{ Manser et al. (2005) } \\
\hline CS3 & & & 0.0276 & 0.0284 & 1.28 & \\
\hline CS1 & \multirow[t]{2}{*}{0.033} & \multirow[t]{2}{*}{0.43} & 0.0723 & 0.0744 & 1.27 & \multirow{2}{*}{$\begin{array}{c}\text { Blackburne et al. } \\
\text { (2008) }\end{array}$} \\
\hline CS3 & & & 0.0379 & 0.0381 & 1.29 & \\
\hline CS1 & \multirow{2}{*}{0.75} & \multirow{2}{*}{1.75} & 0.974 & 1.017 & 1.05 & \multirow{2}{*}{ Guisasola et al. (2005) } \\
\hline CS3 & & & 0.089 & 0.092 & 1.26 & \\
\hline CS1 & \multirow{2}{*}{0.6} & \multirow{2}{*}{1.3} & 0.26 & 0.27 & 1.18 & \multirow{2}{*}{ Wiesmann (1994) } \\
\hline CS3 & & & 0.057 & 0.06 & 1.27 & \\
\hline CS1 & \multirow[t]{2}{*}{0.15} & \multirow{2}{*}{0.11} & 0.0129 & 0.0133 & 1.27 & \multirow{2}{*}{$\begin{array}{l}\text { Picioreanu et al. } \\
\text { (2016) }\end{array}$} \\
\hline CS3 & & & 0.0274 & 0.0282 & 1.28 & \\
\hline CS1 & \multirow{2}{*}{0.36} & \multirow{2}{*}{0.16} & 0.0124 & 0.0129 & 1.27 & \multirow{2}{*}{$\begin{array}{l}\text { Picioreanu et al. } \\
\text { (2016) }\end{array}$} \\
\hline CS3 & & & 0.0275 & 0.0285 & 1.27 & \\
\hline
\end{tabular}




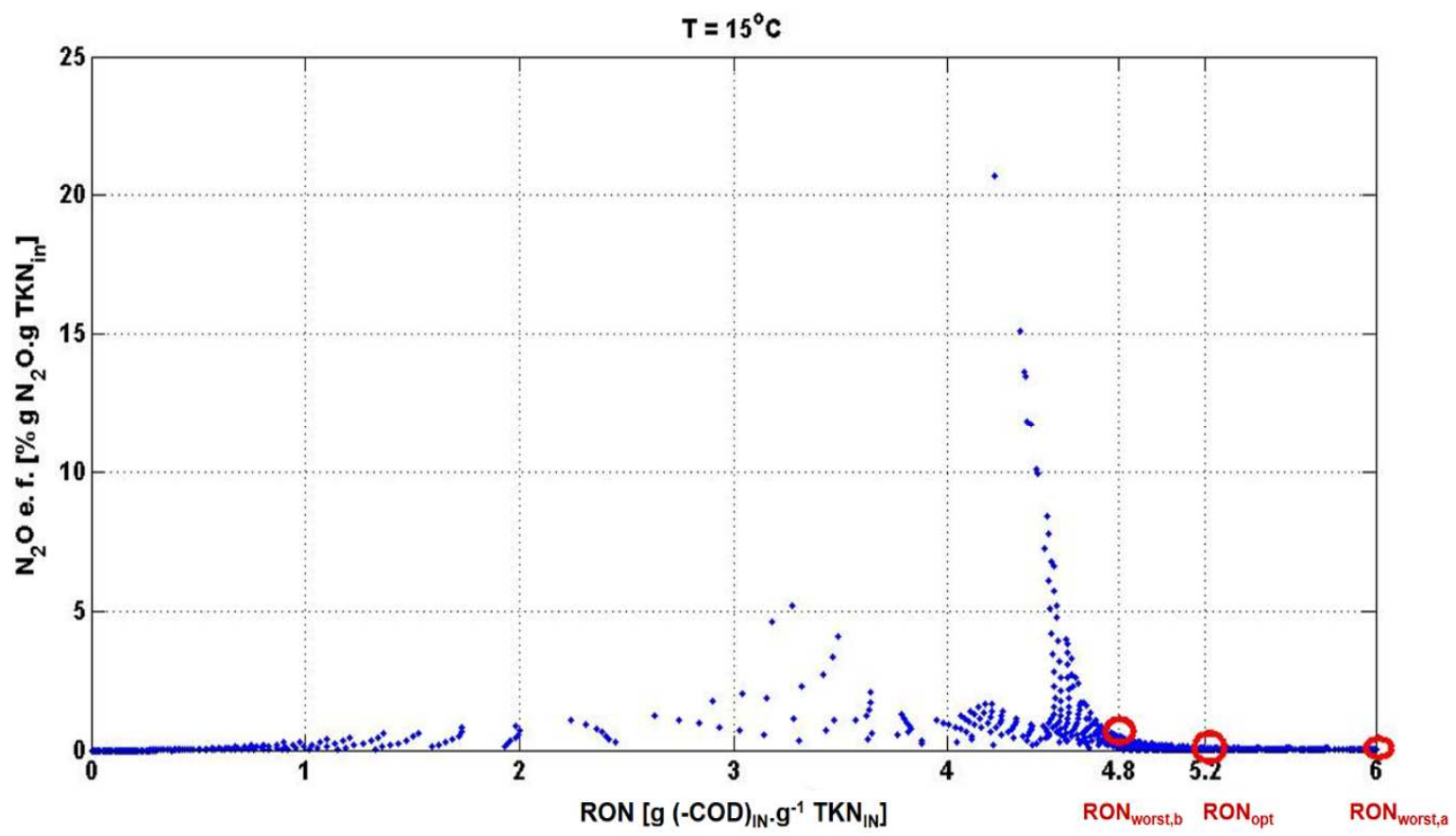




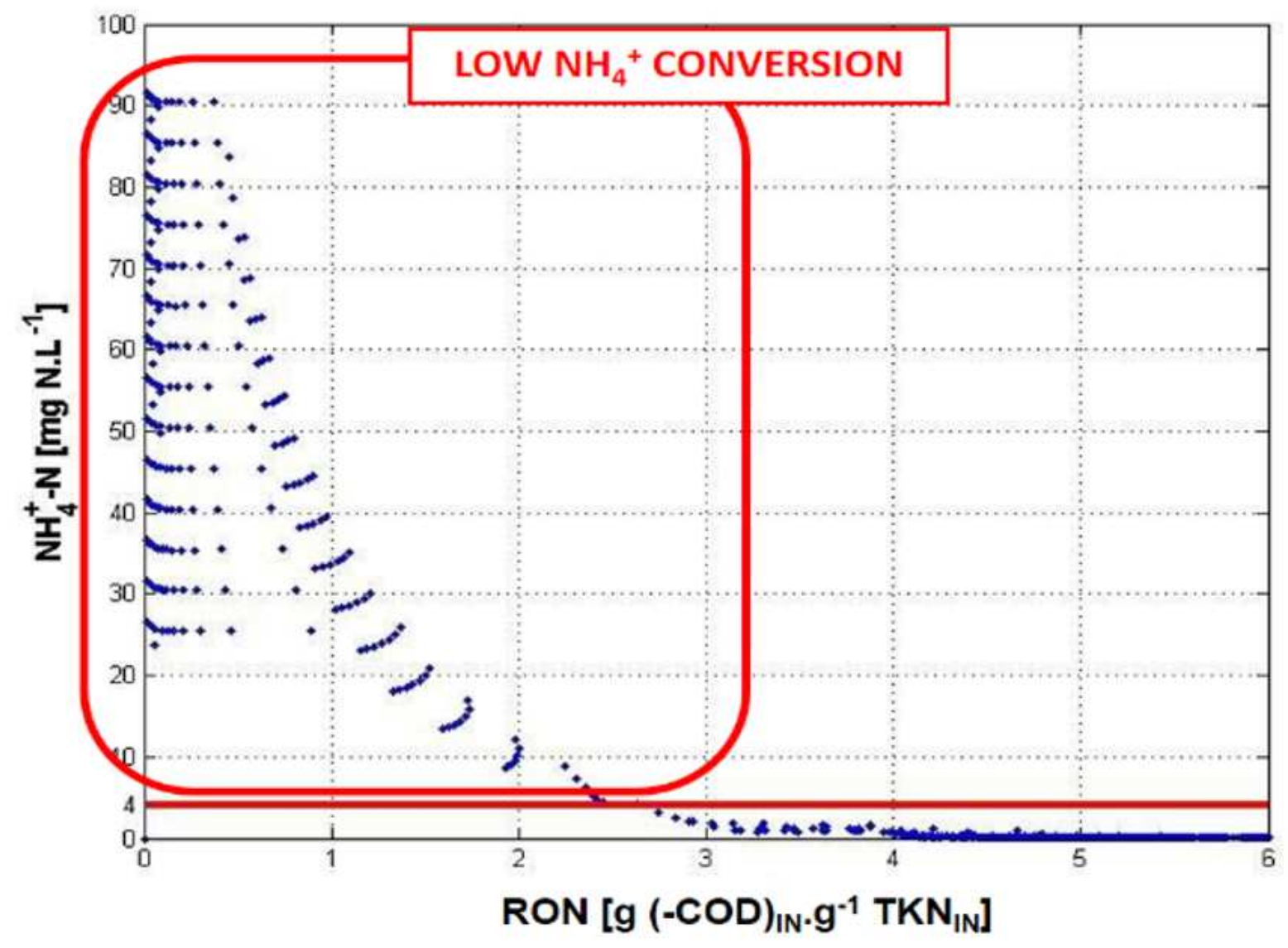




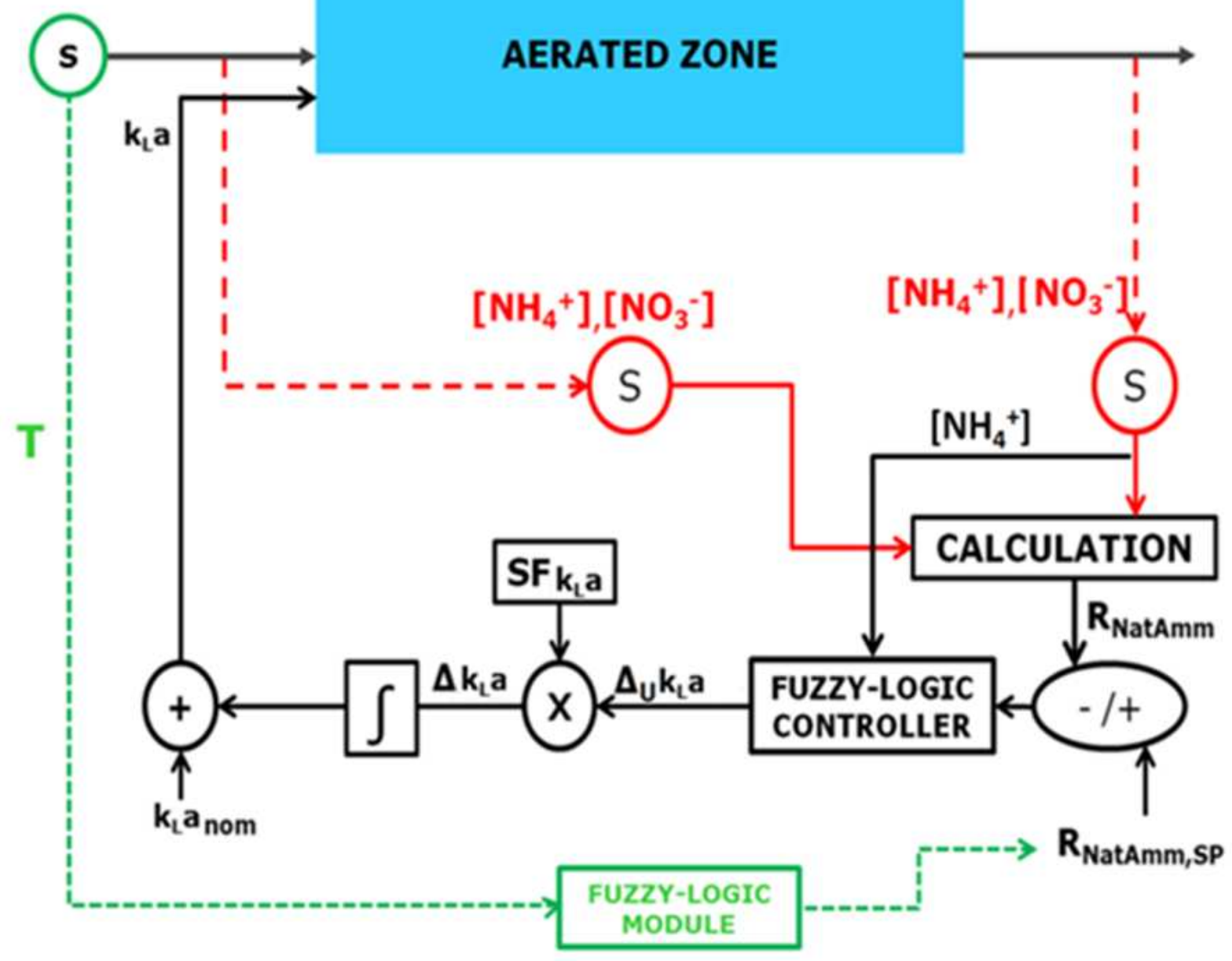




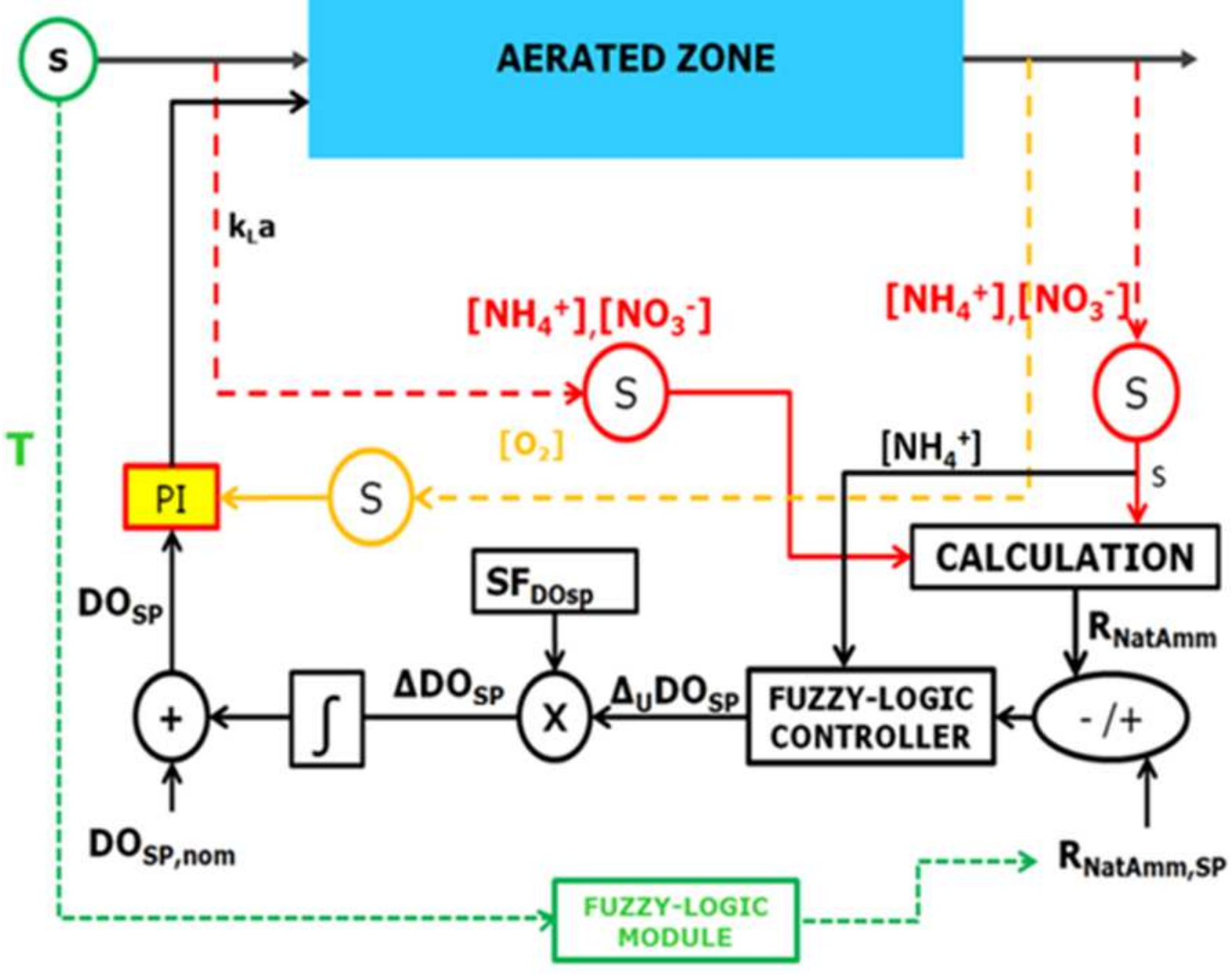



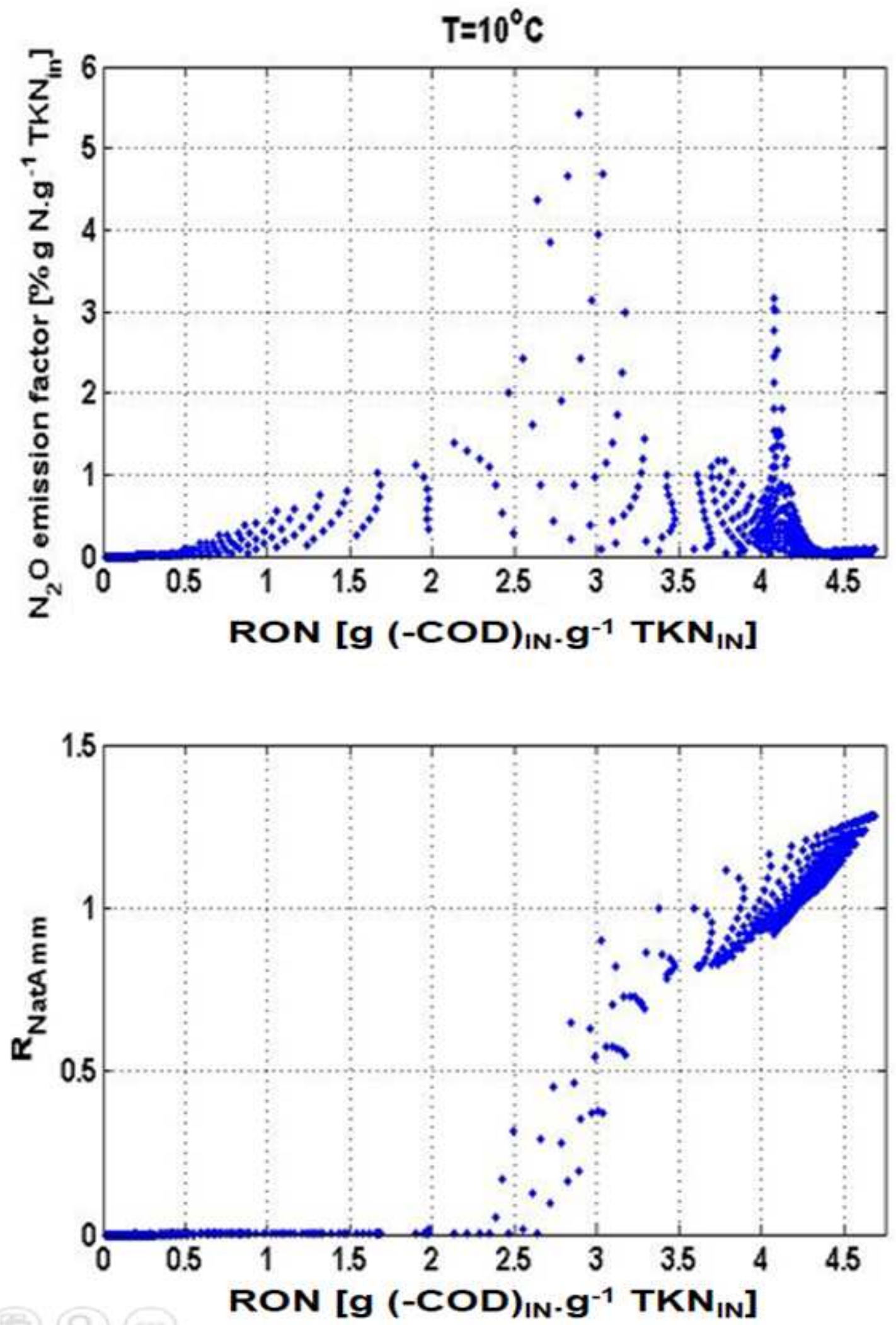

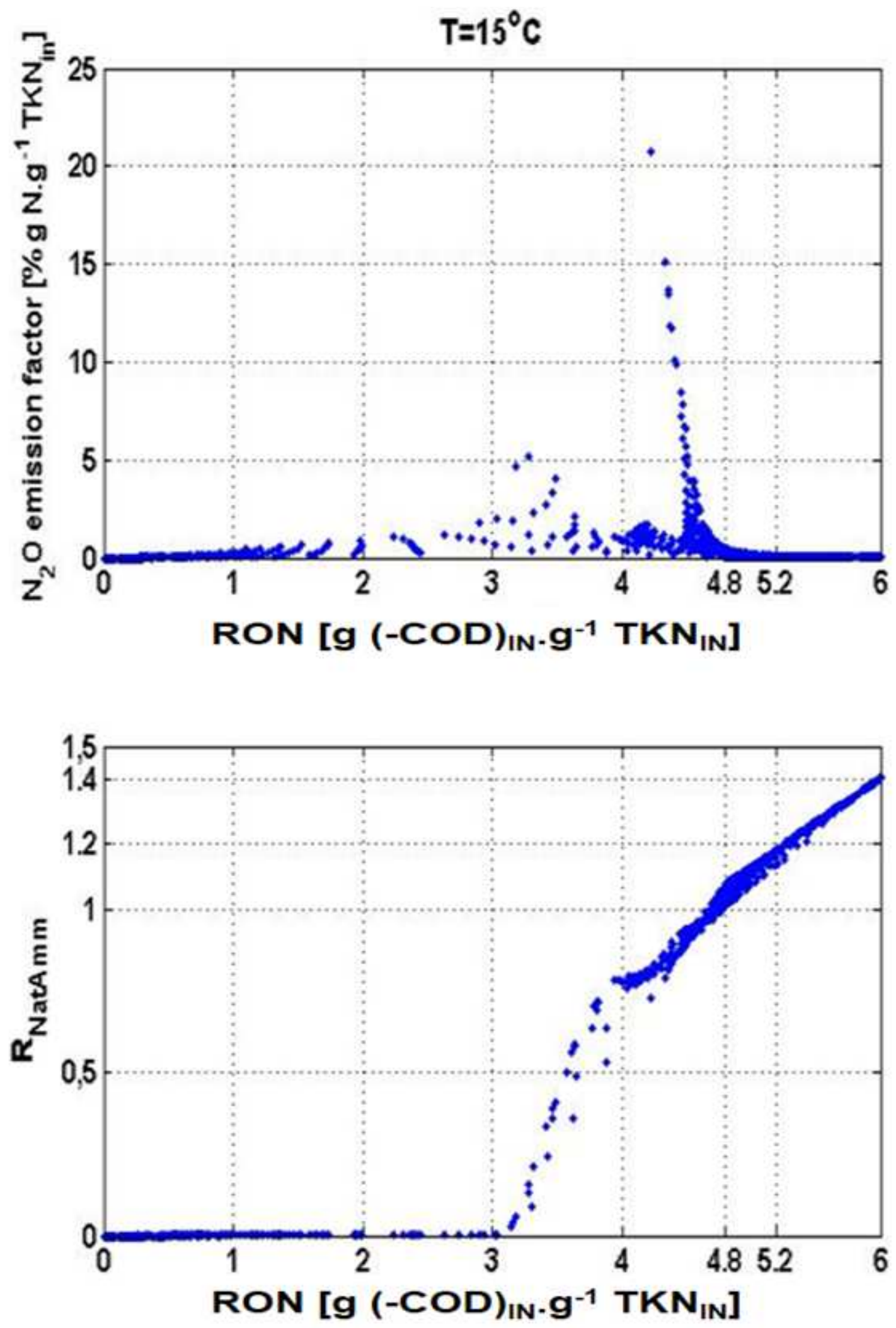

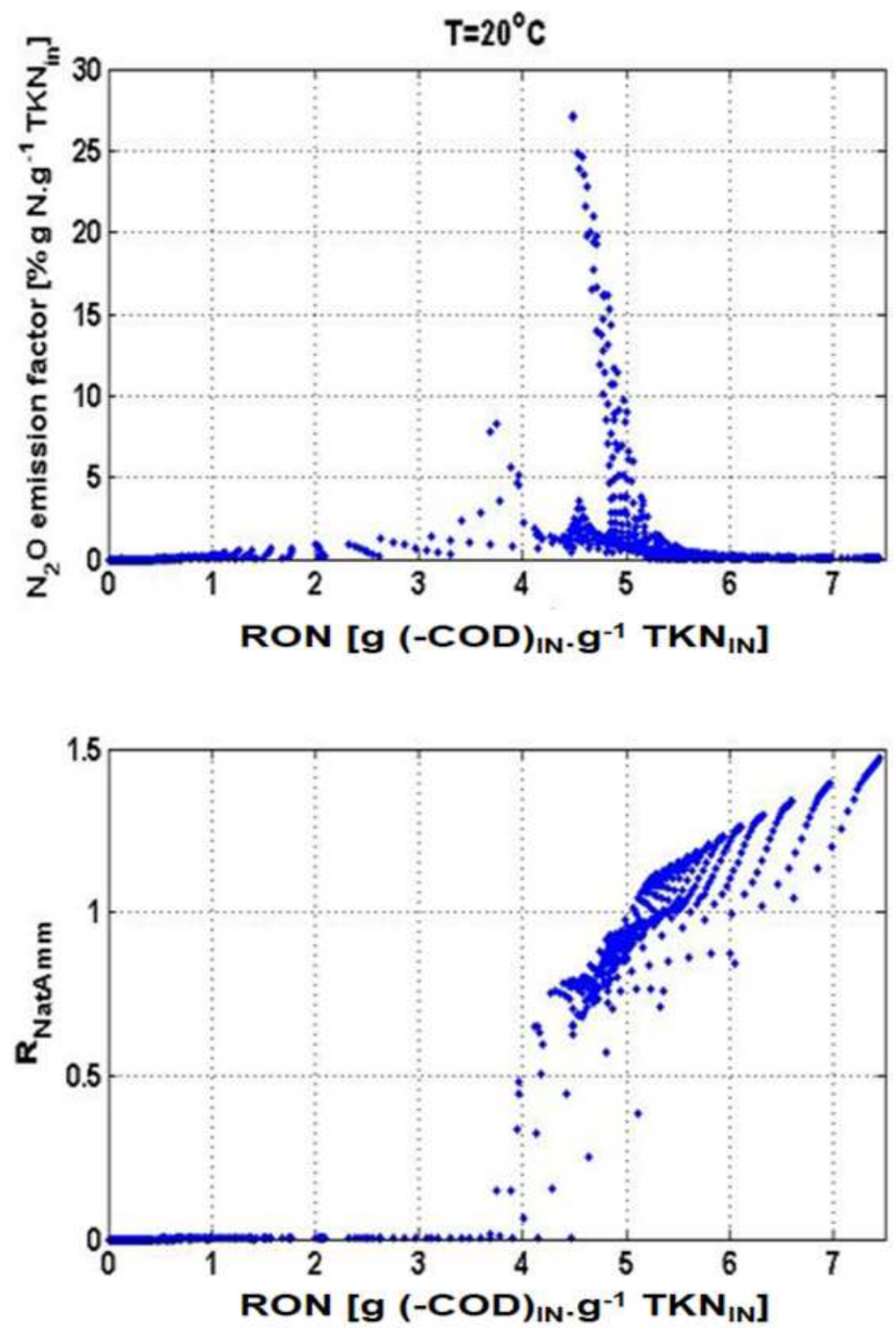


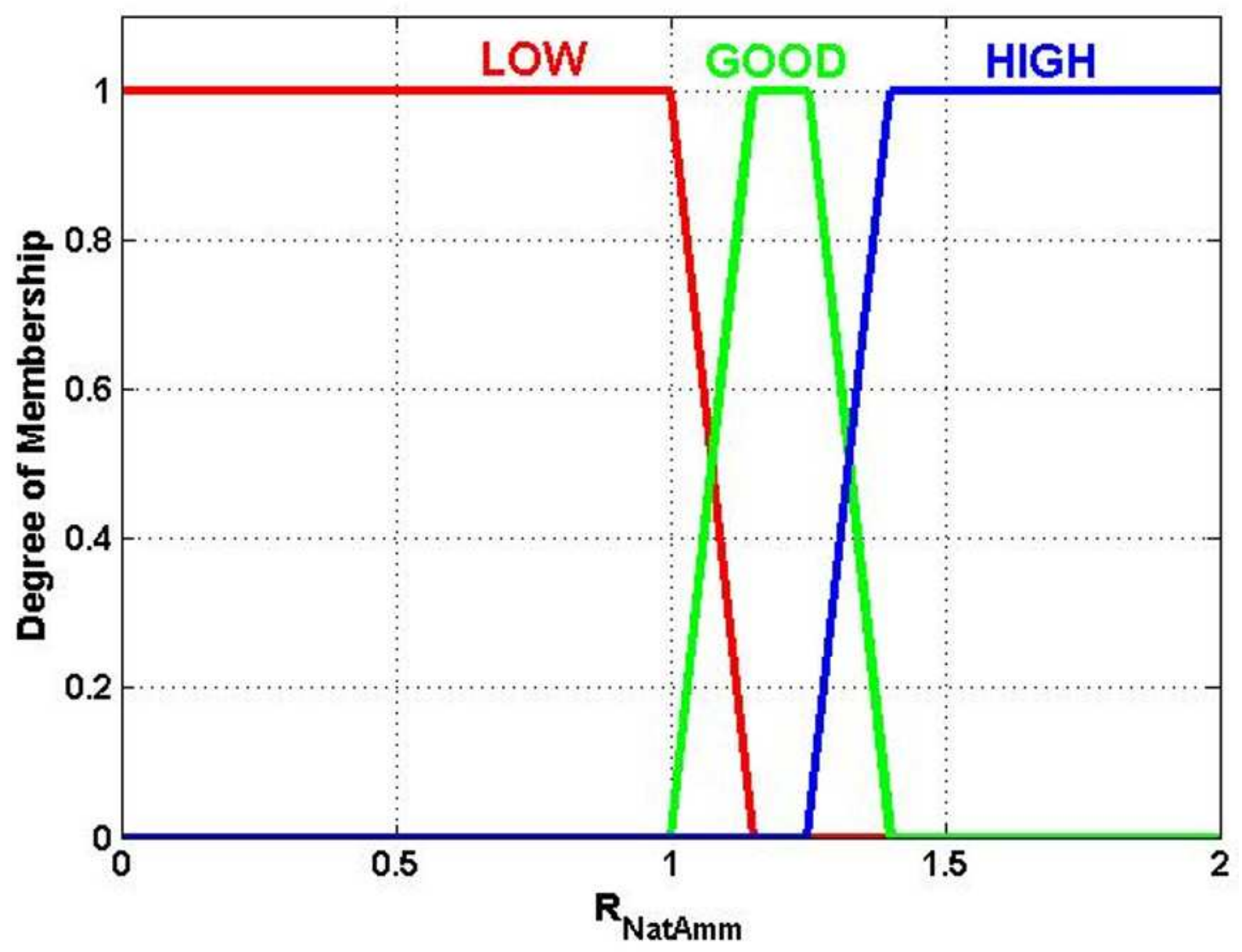




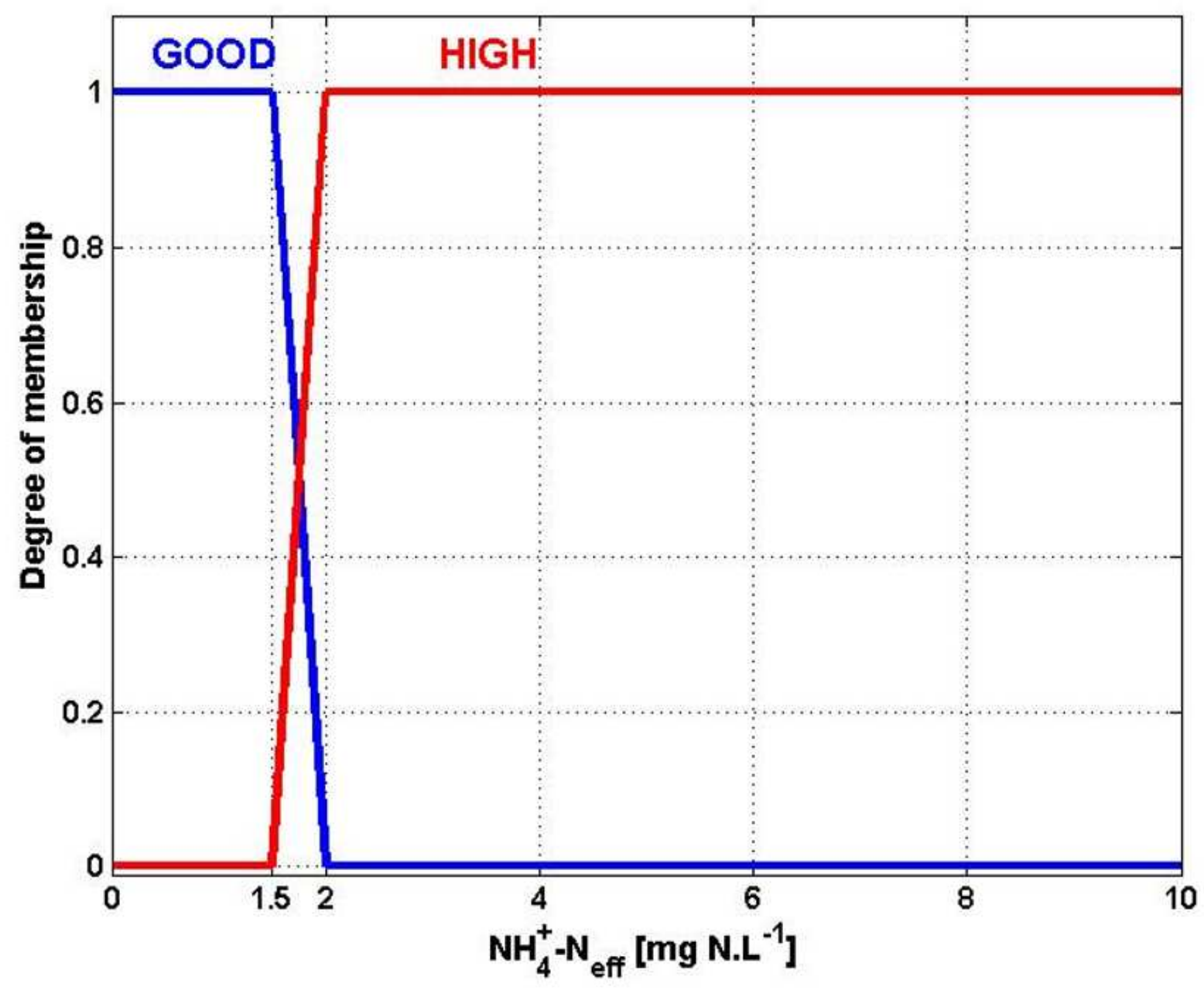




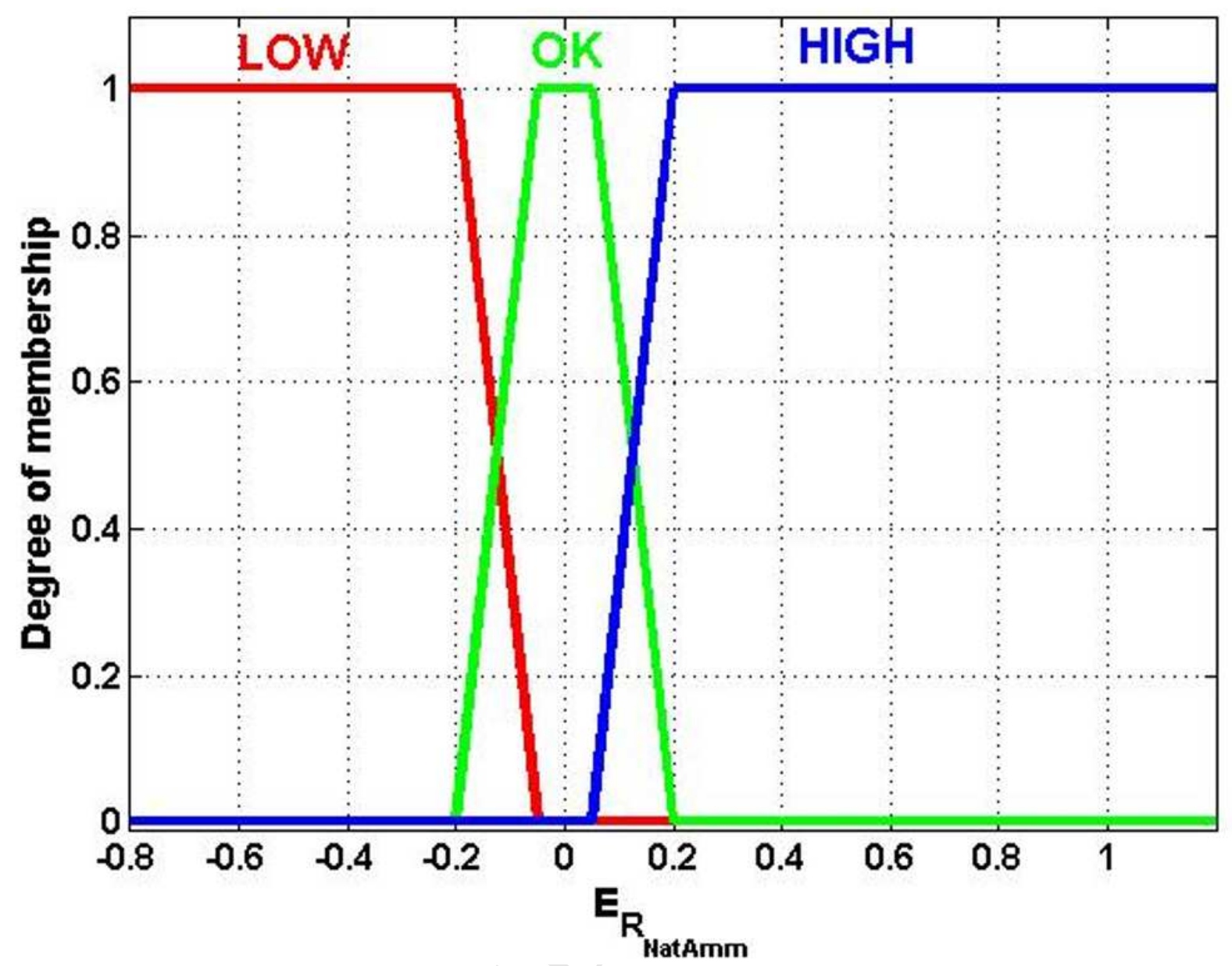




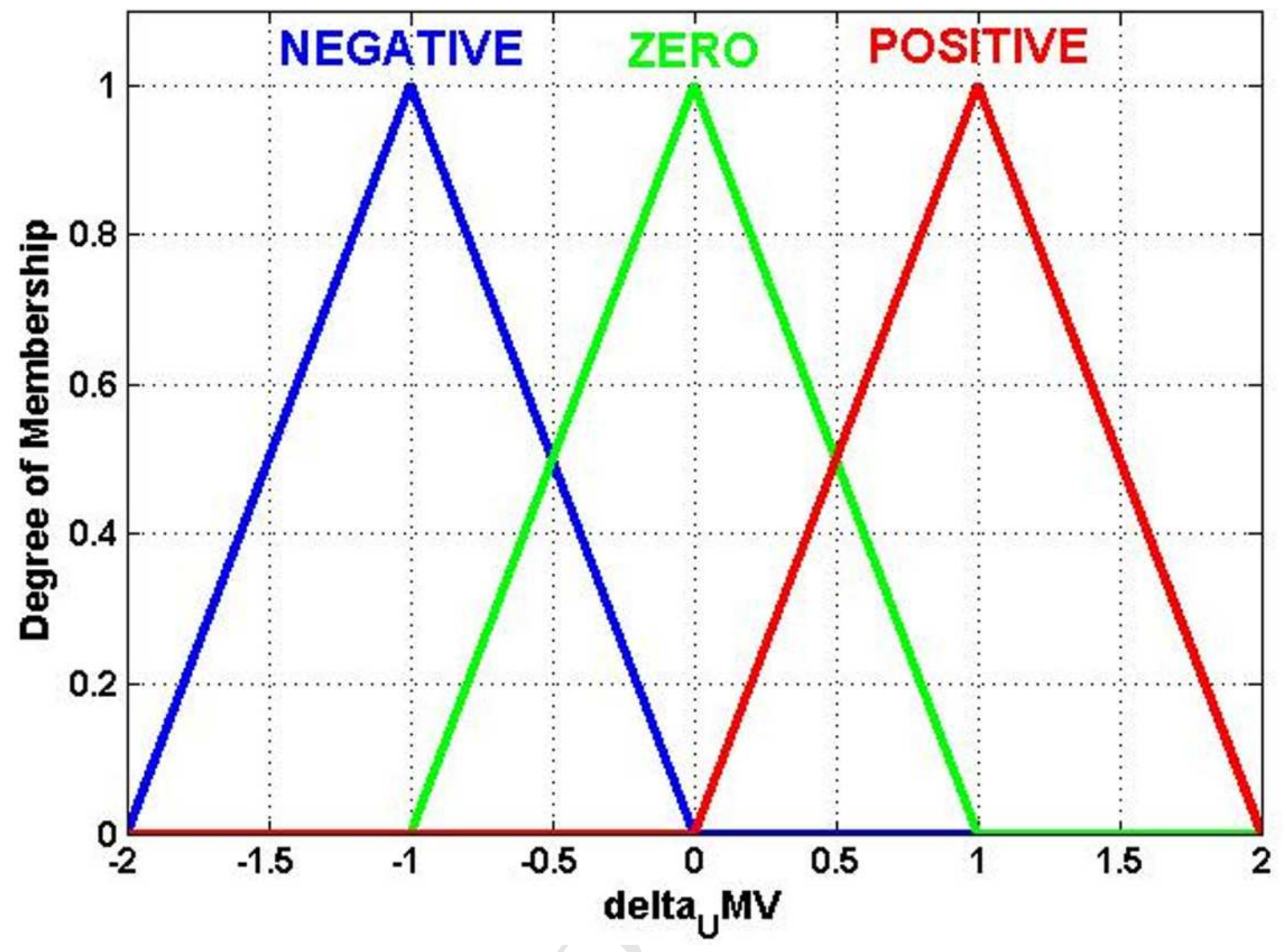




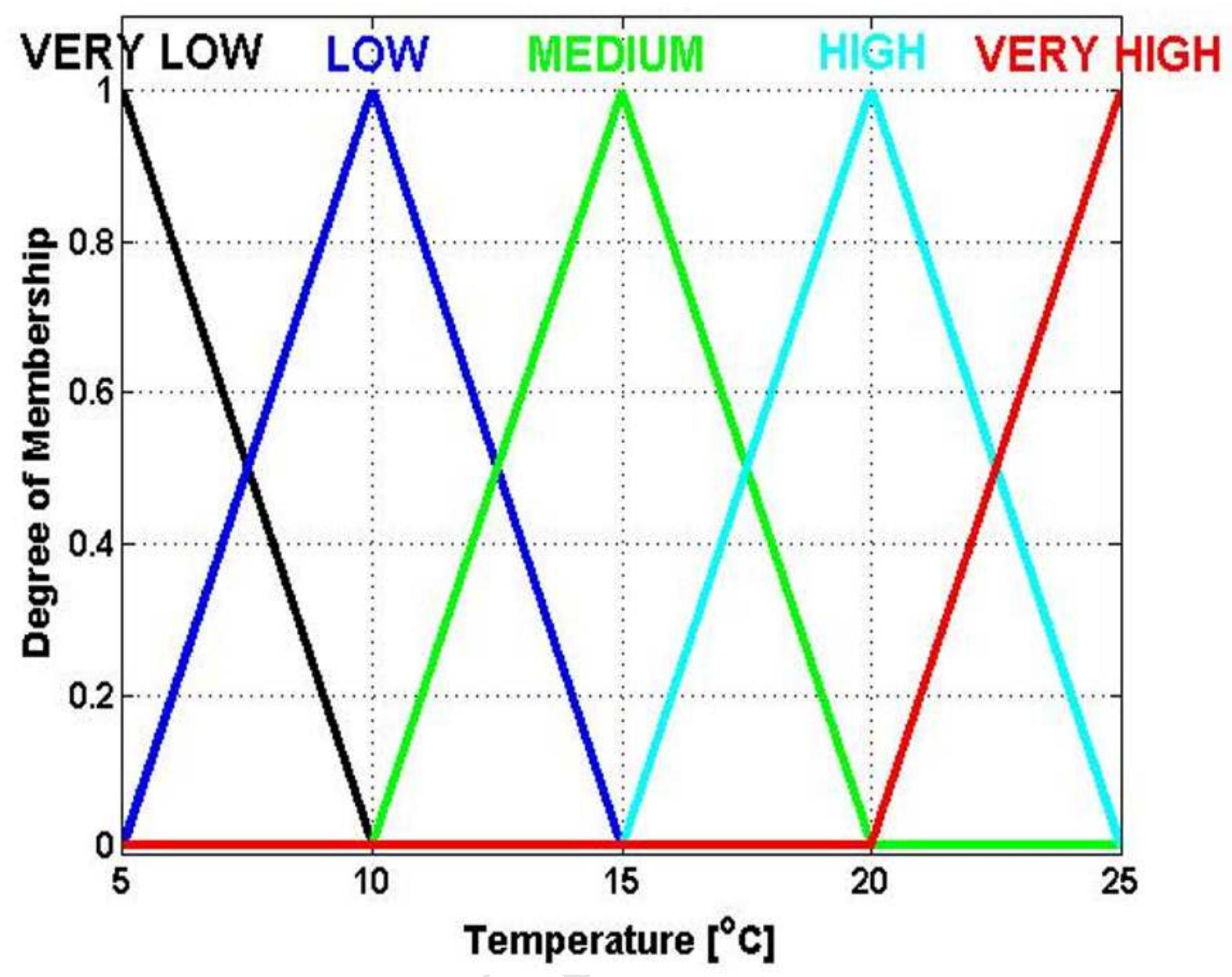




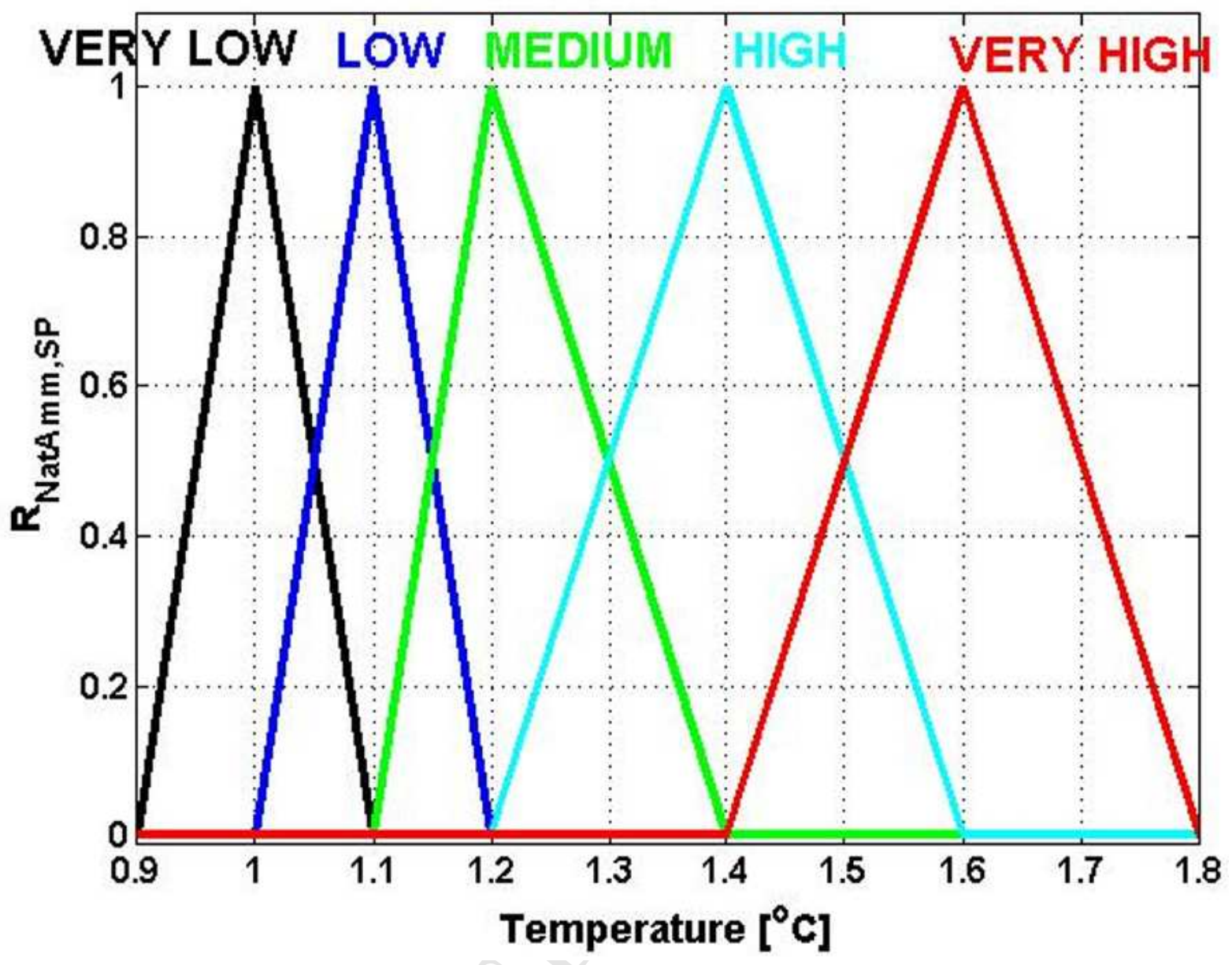




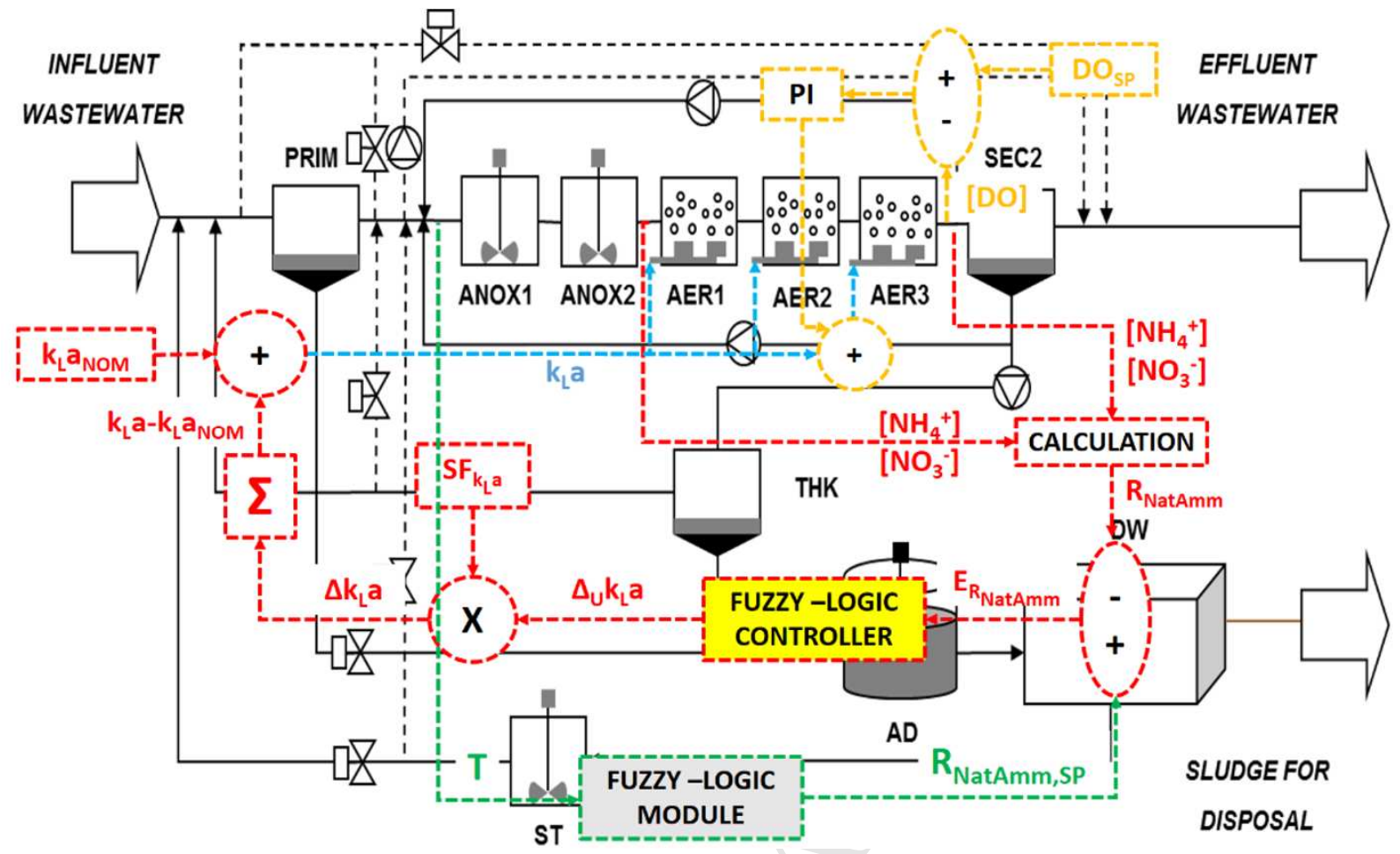




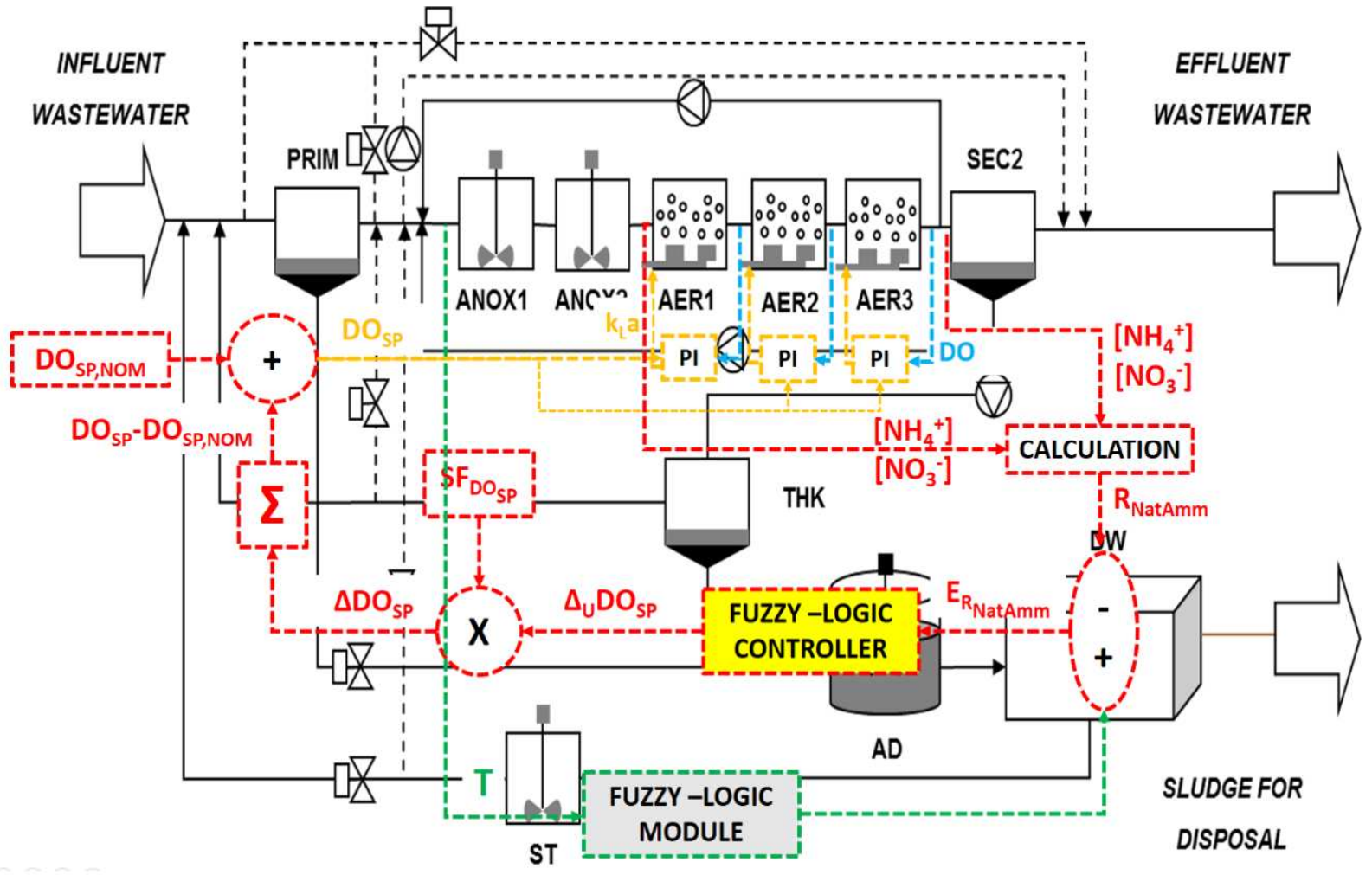




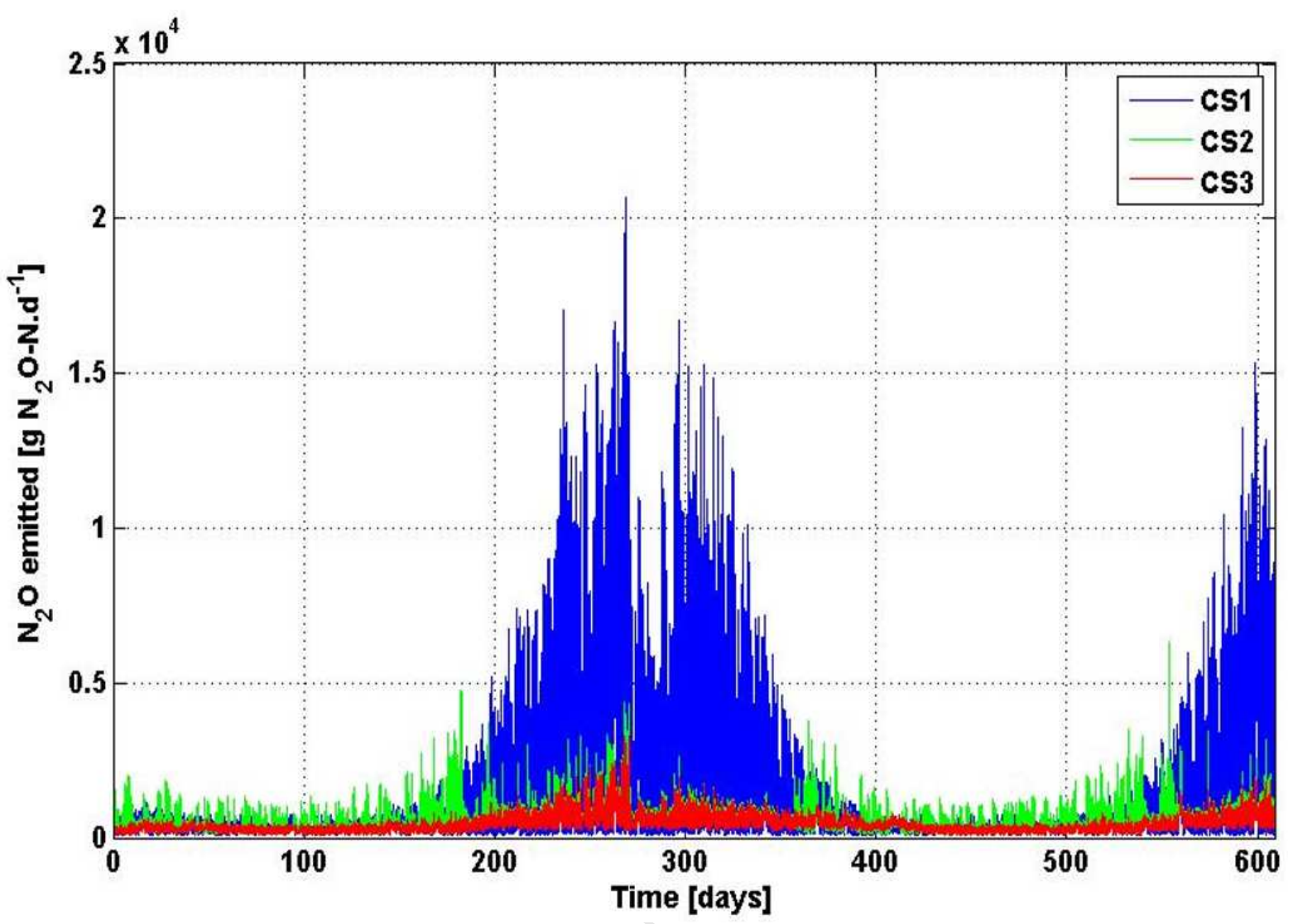




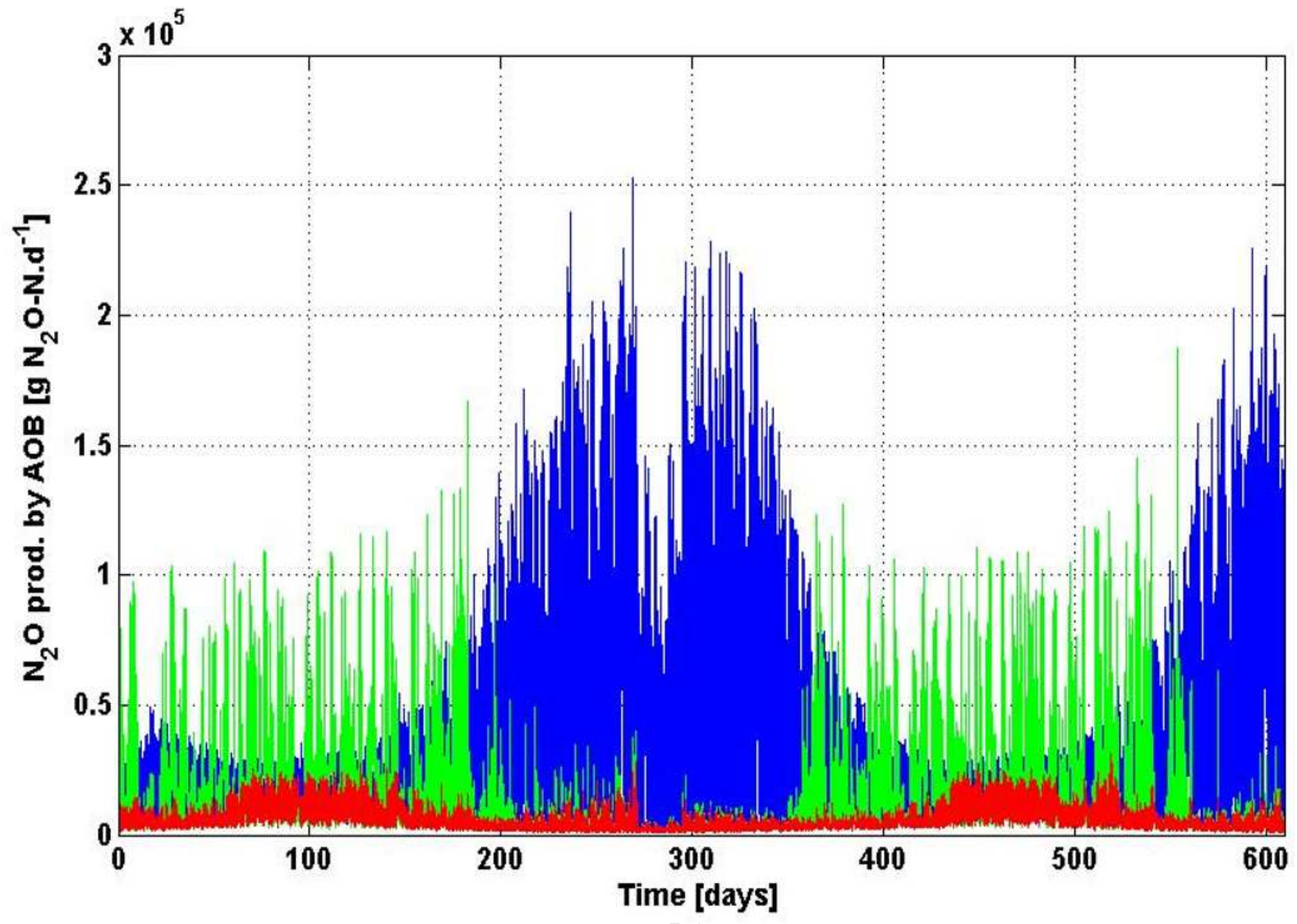




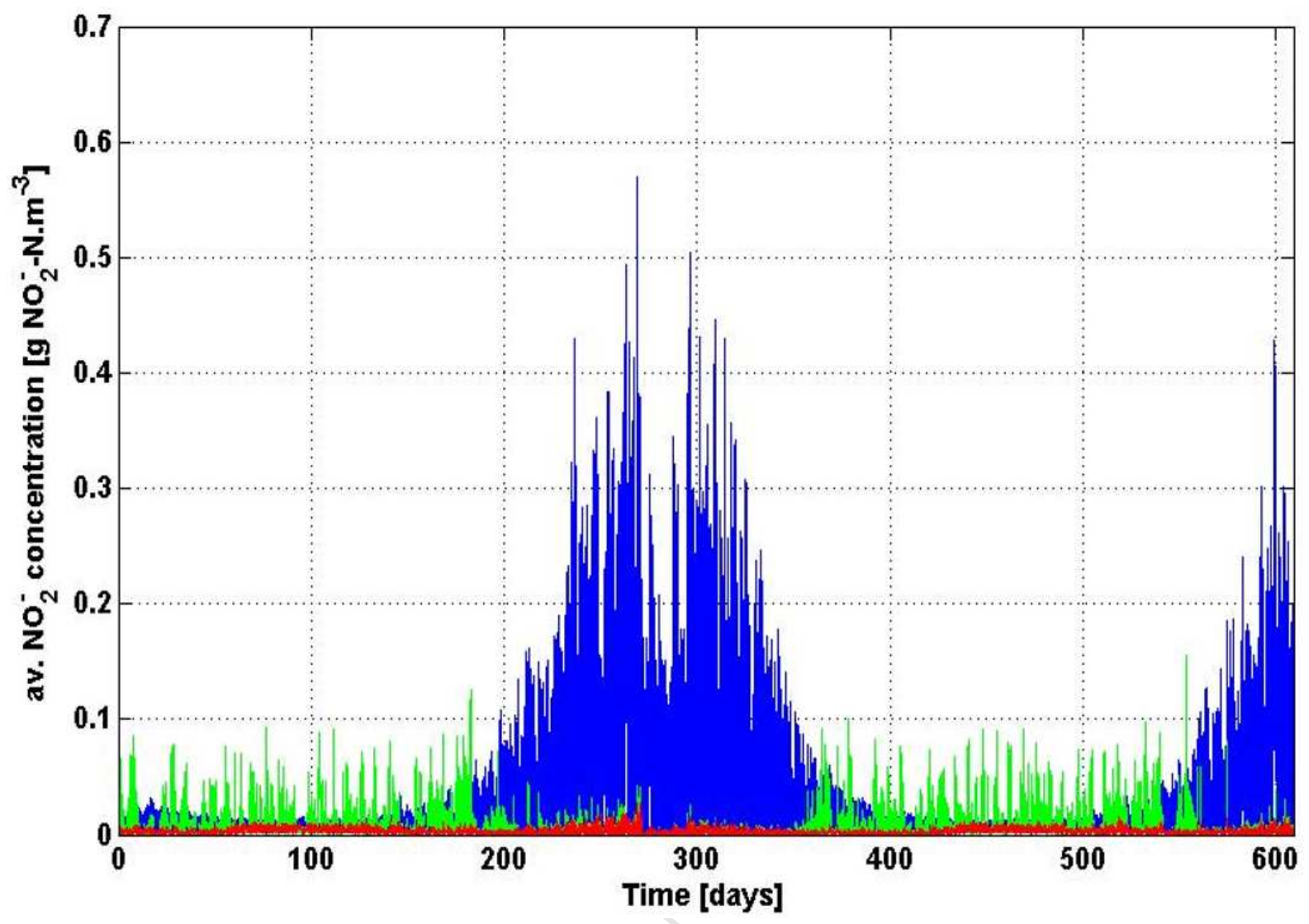




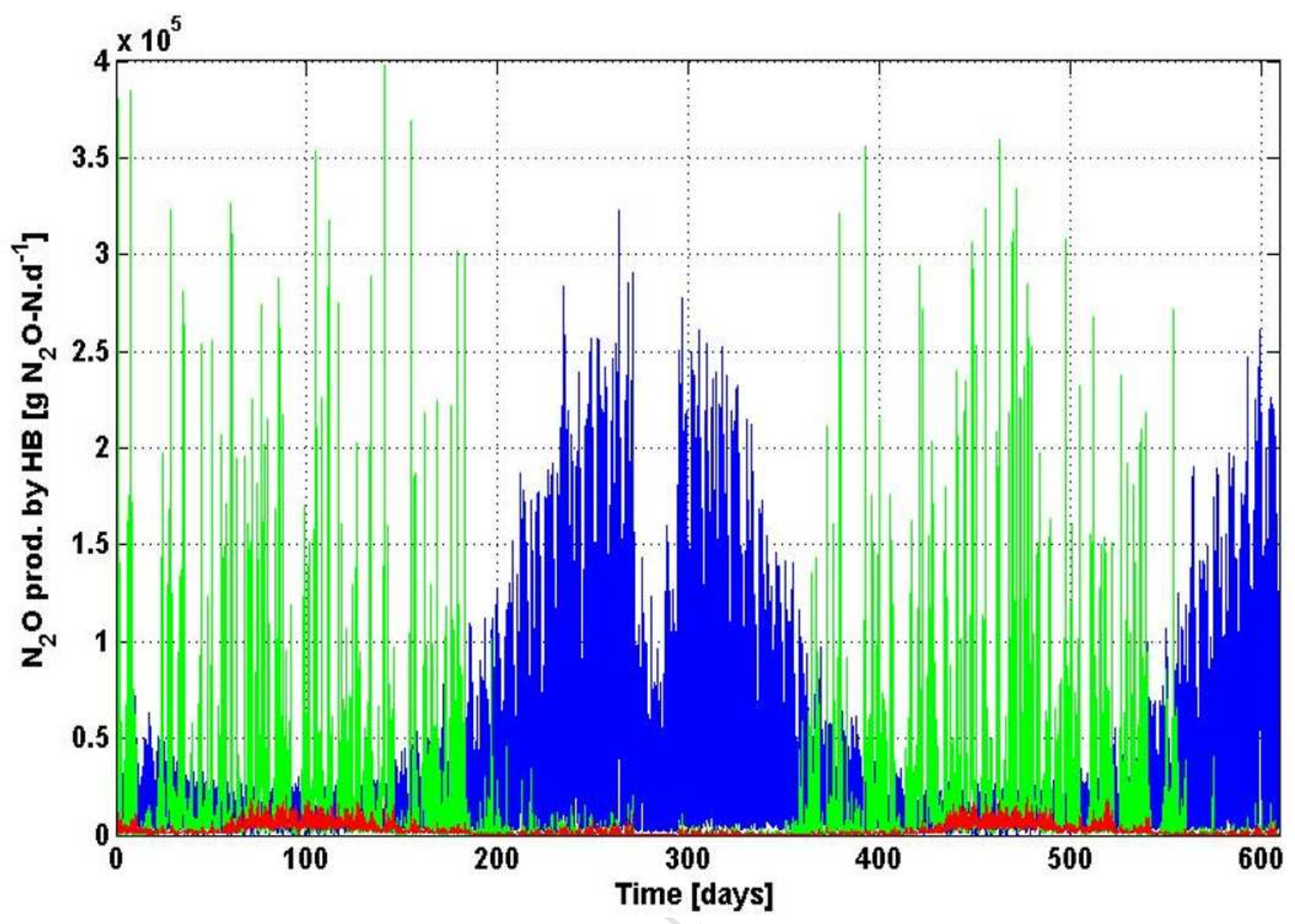




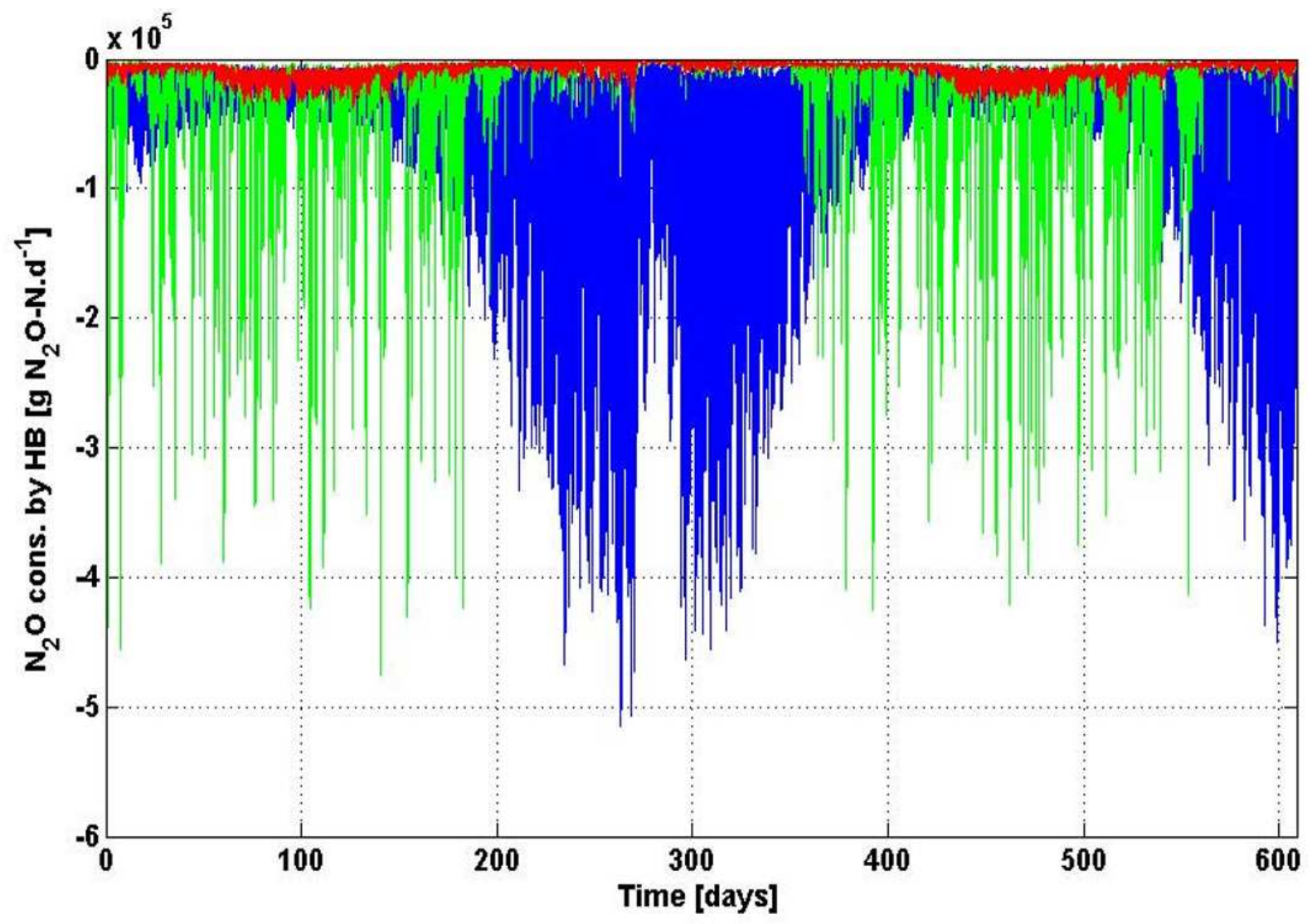




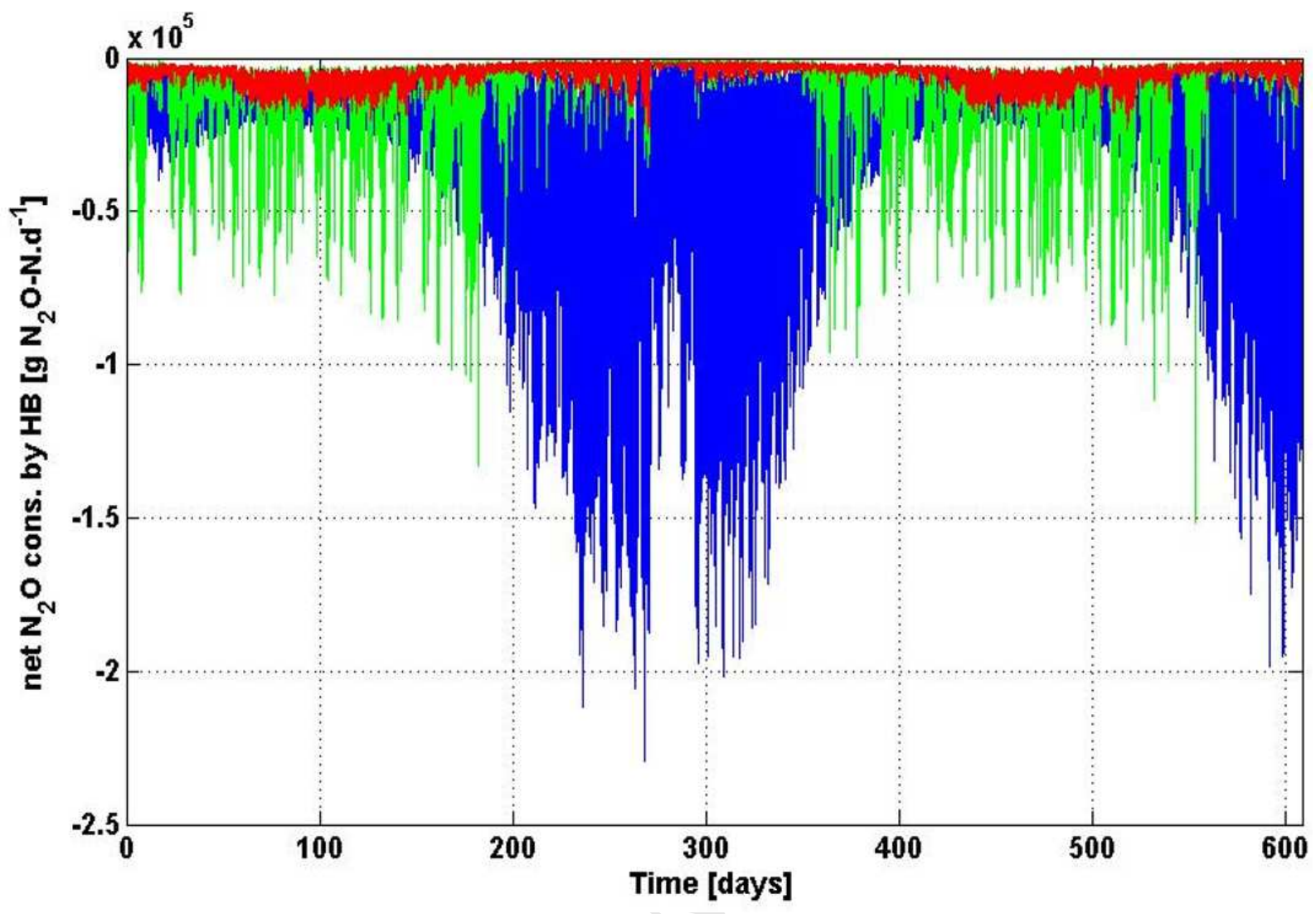

